Portland State University

PDXScholar

TREC Final Reports

Transportation Research and Education Center

(TREC)

$1-2016$

\title{
Encouraging Low-Income Households to Make Location-Efficient Housing Choices
}

Andrée Tremoulet

Portland State University, andree@commonworksconsulting.com

Ryan Dann

Portland State University

Arlie Adkins

University of Arizona

Follow this and additional works at: https://pdxscholar.library.pdx.edu/trec_reports

Part of the Social Policy Commons, Social Welfare Commons, and the Urban Studies and Planning Commons

Let us know how access to this document benefits you.

\section{Recommended Citation}

Tremoulet, Andrée, Dann, Ryan, and Adkins, Arlie. Encouraging Low-Income Households to Make Location-Efficient Housing Choices. NITC-RR-751. Portland, OR: Transportation Research and Education Center (TREC), 2016. https://doi.org/10.15760/trec.2

This Report is brought to you for free and open access. It has been accepted for inclusion in TREC Final Reports by an authorized administrator of PDXScholar. Please contact us if we can make this document more accessible: pdxscholar@pdx.edu. 


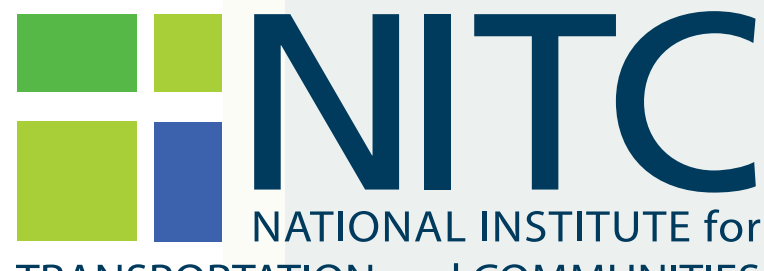

TRANSPORTATION and COMMUNITIES

FINAL REPORT

\section{Encouraging Low-Income Households to Make Location-Efficient Housing Choices}

NITC-RR-751 _ January 2016

NITC is the U.S. Department of Transportation's national university transportation center for livable communities.

\#TREC 


\title{
ENCOURAGING LOW-INCOME HOUSEHOLDS TO MAKE LOCATION-EFFICIENT HOUSING CHOICES
}

\section{Final Report}

\section{NITC-RR-751}

by

\author{
Andrée Tremoulet, Ph.D. \\ Ryan J. Dann \\ Portland State University \\ with \\ Arlie Adkins, Ph.D. \\ University of Arizona
}

for

National Institute for Transportation and Communities (NITC)

P.O. Box 751

Portland, OR 97207
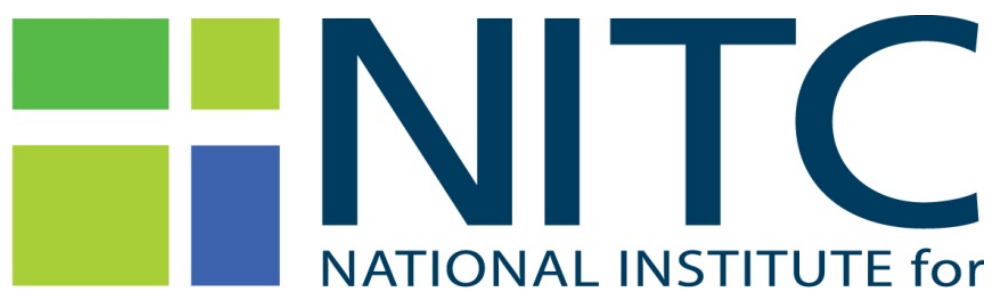

TRANSPORTATION and COMMUNITIES

January 2016 



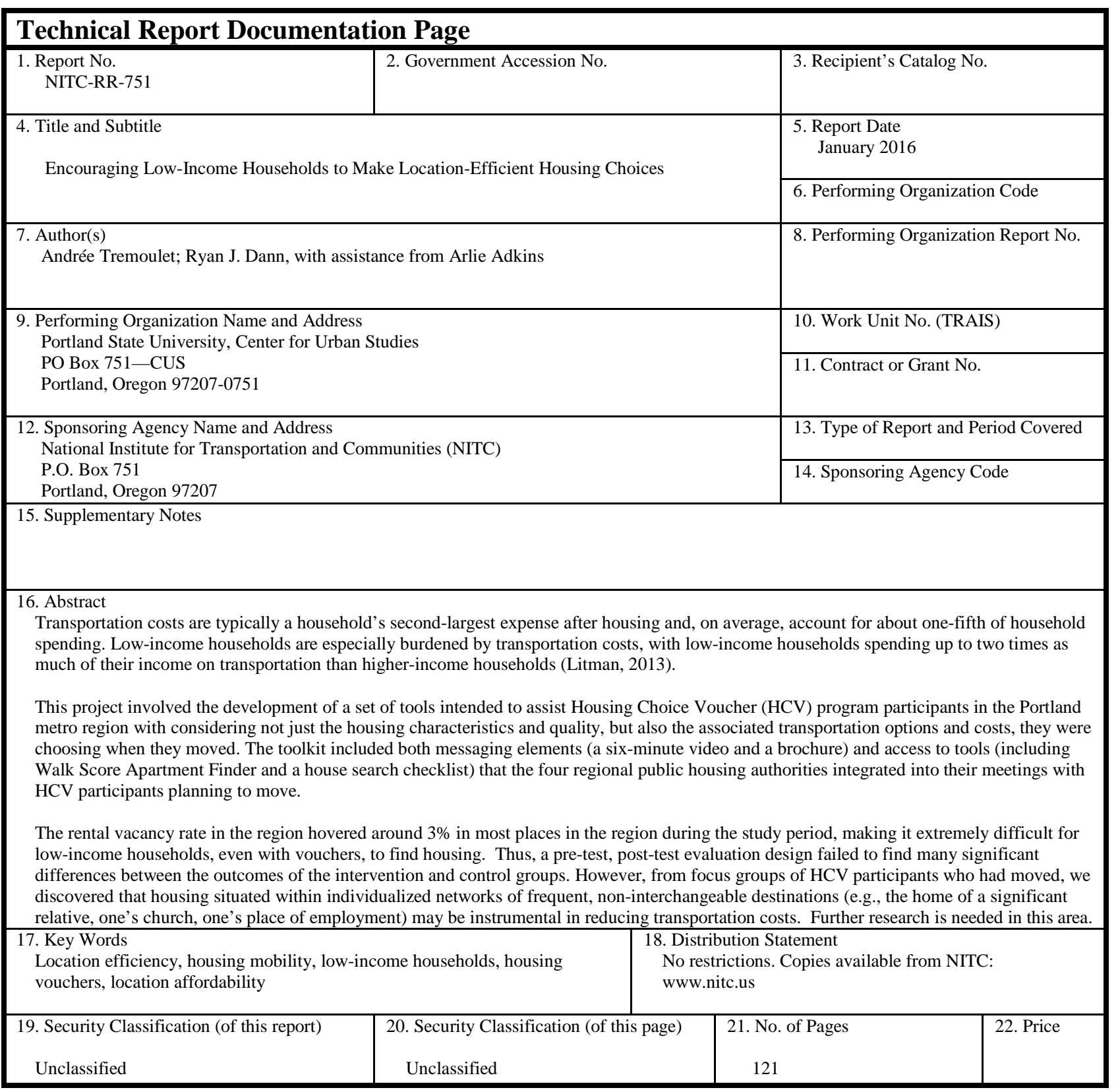




\section{ACKNOWLEDGEMENTS}

This project was supported with funding from the US Department of Transportation Federal Transit Administration; Metro, the regional government of the Portland metropolitan area; Home Forward (formerly the Housing Authority of Portland); Housing Authority of Washington County; Vancouver Housing Authority; Housing Authority of Clackamas County; and The National Institute for Transportation and Communities (NITC), a program of the Transportation Research and Education Center (TREC) for Portland State University.

We also would like to acknowledge the support received from the leadership of each housing authority throughout this project and Metro's Regional Transportation Options Work Group. Finally, we wish to acknowledge the considerable contributions of the members of the project Steering Committee: Rebecca Nesbit (Home Forward), Kim Armstrong (Housing Authority of Washington County), Jan Wichert (Vancouver Housing Authority), and Mary-Rain O'Meara and Elizabeth Miller (Housing Authority of Clackamas County).

\section{DISCLAIMER}

The contents of this report reflect the views of the authors, who are solely responsible for the facts and the accuracy of the material and information presented herein. This document is disseminated under the sponsorship of the U.S. Department of Transportation University Transportation Centers Program, the U.S. Department of Transportation Federal Transit Administration, Metro - the regional government of the Portland metropolitan area, Home Forward (formerly the Housing Authority of Portland), Housing Authority of Washington County, Vancouver Housing Authority and Housing Authority of Clackamas County in the interest of information exchange. The U.S. Government, the U.S. Department of Transportation University Transportation Centers Program, the US Department of Transportation Federal Transit Administration, Metro - the regional government of the Portland metropolitan area, Home Forward, Housing Authority of Washington County, Vancouver Housing Authority and Housing Authority of Clackamas County assumes no liability for the contents or use thereof. The contents do not necessarily reflect the official views of the U.S. Government and the U.S. Department of Transportation Federal Transit Administration, Metro - the regional government of the Portland metropolitan area, Home Forward, Housing Authority of Washington County, Vancouver Housing Authority or Housing Authority of Clackamas County. This report does not constitute a standard, specification, or regulation. 


\section{TABLE OF CONTENTS}

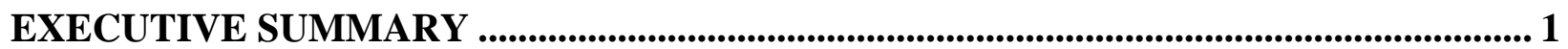

BACKGROUND INTERVIEWS AND FOCUS GROUPS …........................................... 1

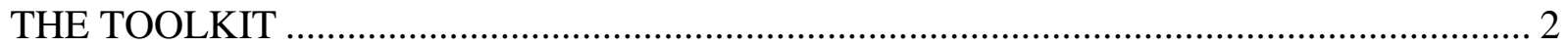

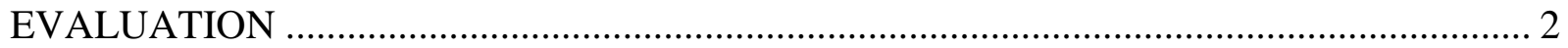

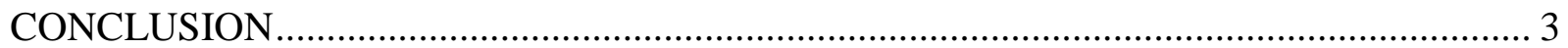

1.0 PROBLEM STATEMEMENT AND APPROACH ...................................................... 5

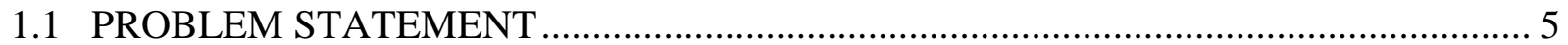

1.2 THE HOUSING CHOICE VOUCHER PROGRAM, HOUSING MOBILITY AND

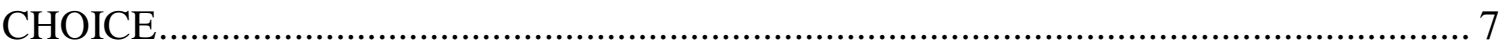

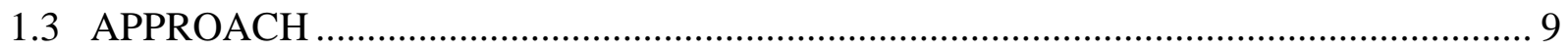

2.0 CONTEXT FOR THE STUDY …...................................................................... 11

2.1 THE PORTLAND METRO REGION HOUSING MARKET ………............................ 11

2.2 INSTITUTIONAL CONTEXT ………………………….......................................... 15

2.2.1 The Housing Choice Voucher Program............................................................... 15

2.2.2 Four Housing Authorities in the Portland Metro Region........................................... 16

2.2.2.1 Potential Sources of Mobility Program Participants ............................................. 18

2.2.2.2 Views on Housing Opportunities for HCV Participants Movers in 2013.............. 18

2.2.2.3 Opportunity-Rich, Location-Efficient Housing.................................................... 20

2.2.2.4 Participant Choices about Moving .............................................................. 21

2.2.2.5 Process for Moves..................................................................................... 22

2.2.2.6 Relevant Housing Authority Policies ................................................................... 23

2.2.2.7 Conclusions about Policies and Practices.............................................................. 24

2.3 EXPERIENCES OF HCV PARTICIPANT MOVERS IN THE REGION ...................... 26

2.3.1 Focus Group Design, Methods and Analytical Approach ......................................... 26

2.3.2 Analysis and Findings from Focus Groups............................................................... 27

$3.0 \quad$ TOOLKIT DEVELOPMENT ............................................................................ 31

3.1.1 Development of the Toolkit Framework...…………….............................................. 31

3.1.2 Focus Group Testing........................................................................................... 31

3.1.2.1 Potential Online Tools .................................................................................... 31

3.1.2.2 Online Tool Feedback....................................................................................... 32

3.1.3 Housing Authority Feedback .................................................................................... 33

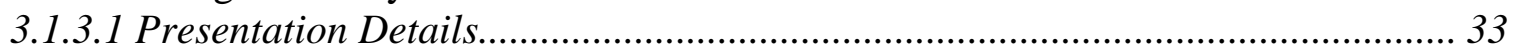

3.1.3.2 Feedback from Presentation 1 ............................................................................ 34

3.1.3.3 Feedback from Presentation 2 ......................................................................... 35

3.1.3.4 Conclusions Regarding Housing Authority Feedback........................................... 35

3.1.4 Messaging Pieces ............................................................................................................. 36

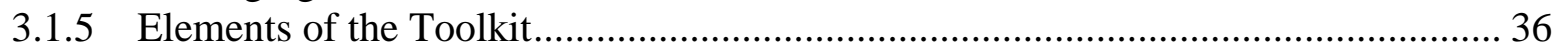

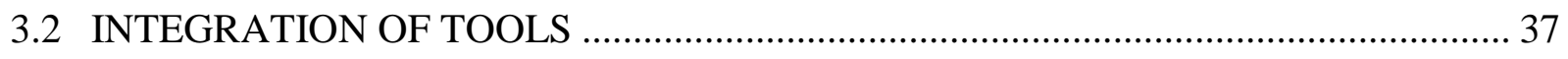

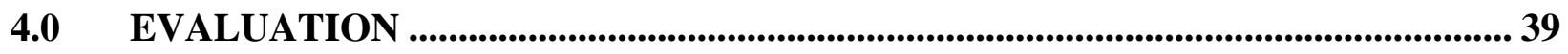

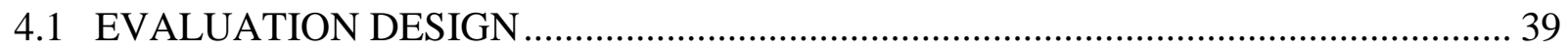

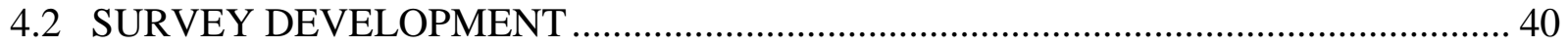

4.2.1 Theoretical Background ........................................................................................... 40

4.2.2 Question Development and Refinement ................................................................... 41 


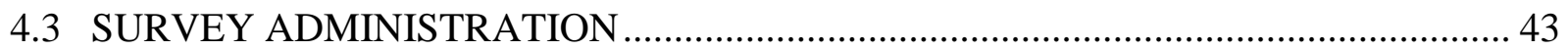

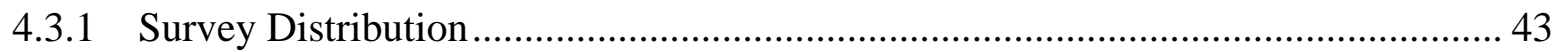

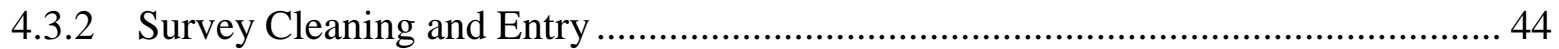

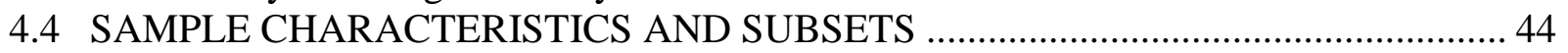

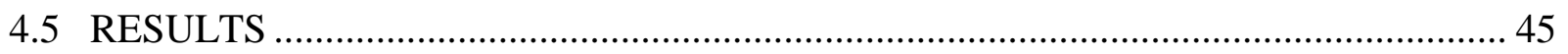

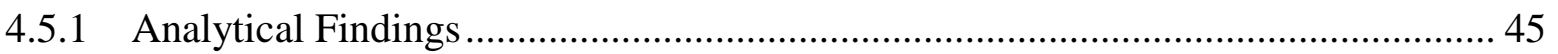

4.5.2 Additional Findings ............................................................................................... 47

5.0 DISCUSSION AND RECOMMENDATIONS............................................................. 51

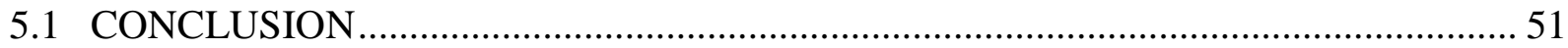

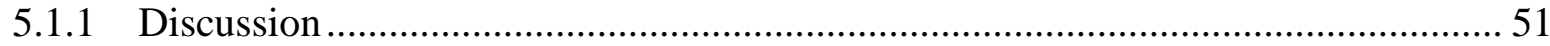

5.1.2 Key Findings ....................................................................................................... 53

5.1.3 Additional Findings …………………………................................................... 54

5.2 RECOMMENDATIONS ………………………….............................................. 54

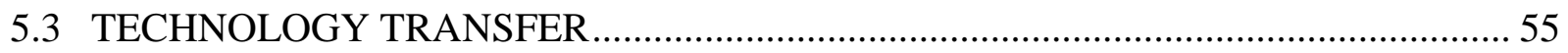

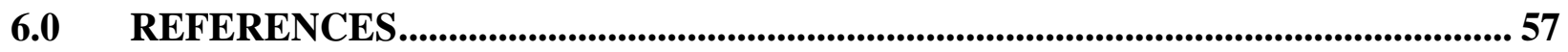

\section{APPENDICES}

APPENDIX A: PROJECT TIMELINE

APPENDIX B1: PROTOCOLS FOR HOUSING AUTHORITY STAFF INTERVIEWS

APPENDIX B2: PHA POLICIES AND PROCEDURES

APPENDIX B3: INSTRUCTIONS TO HOUSING AUTHORITIES REGARDING

RECRUITMENT OF FOCUS GROUP PARTICIPANTS

APPENDIX B4: FOCUS GROUP GUIDE

APPENDIX B5: APPROVED HUMAN SUBJECTS CONSENT FORM TEXT

APPENDIX C1: TOOLBOX: MESSAGING PAMPHLET

APPENDIX C2: TOOLBOX: INTRODUCTORY VIDEO

APPENDIX C3: TOOLBOX: WALKSCORE GUIDE

APPENDIX C4: TOOLBOX: HOUSE FINDING CHECKLIST

APPENDIX C5: TOOLBOX: TRANSPORTATION AND HOUSING COST COMPARISON WORKSHEET

APPENDIX C6: TOOLBOX: PHA WEBSITE INTRODUCTORY TEXT

APPENDIX D1: CONTROL GROUP PRE-MOVE SURVEY

APPENDIX D2: INTERVENTION GROUP PRE-MOVE SURVEY

APPENDIX D3: CONTROL/INTERVENTION GROUP POST-MOVE SURVEY

APPENDIX E: PROJECT INFORMATION SHEET FOR PARTICIPANTS 


\section{LIST OF TABLES}

Table 2.1: Rental Vacancy Rate Estimates, 2010 - 2014......................................................... 12

Table 2.2: Profile of Housing Voucher Programs in Portland Metropolitan Area 2012 ............. 17

Table 2.3: HCV Participants’ Reasons for Moving .......................................................... 21

Table 4.1: Sample Descriptive Statistics .......................................................................... 44

Table 4.2: Perceived Behavioral Control, Walking and Transit Access................................... 46

Table 4.3: Changes in Housing and Transportation Costs.................................................... 46

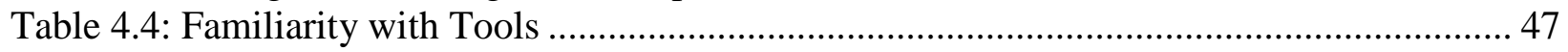

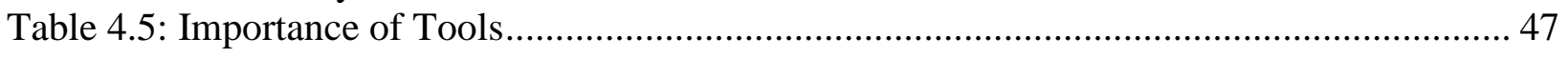

Table 4.6: Factors Influencing Choice of Home............................................................... 48

Table 4.7: Transportation Mode After Moving: Intention and Behavior ................................ 49

Table 4.8: Transportation Mode Share Shift: Pre-Move Home and Post-Move Home............... 49

\section{LIST OF FIGURES}

Figure 2.1: Multifamily Vacancy Rate Estimates, 2013-2015 .............................................. 12

Figure 2.2: Voucher Lease-up Success Rates, 2011-2015.................................................. 13

Figure 2.3: Home Forward, Average Days to Lease Unit, 2010-2015 .................................. 14

Figure 2.4: Housing Authority of Washington County Lease-up Time, 2011-2014 .................. 15

Figure 4.1: Theory of Planned Behavior.......................................................................... 40 


\section{EXECUTIVE SUMMARY}

The purpose of this project is to develop and evaluate tools to assist Housing Choice Voucher (HCV) program participants in the Portland, OR, metro region with considering transportation needs and options when making decisions about where to live. The project consists of two elements: development of a set of tools in collaboration with the four metro-area housing authorities, and an evaluation of the effectiveness of the tools. The four housing authorities conceptualized and initiated this project, and then selected our team to fully design and complete it.

Transportation costs are typically a household's second-largest expense after housing and, on average, account for about one-fifth of household spending. Low-income households are especially burdened by transportation costs, with low-income households spending up to two times as much of their income on transportation than higher-income households (Litman, 2013). Thus, reducing transportation costs is likely to have a disproportionately positive effect on the budgets of low-income households, both because of the share of their budgets it claims and because they have little to no discretionary resources to absorb higher transportation costs without impacting their ability to purchase other essentials, such as food and health care.

\section{BACKGROUND INTERVIEWS AND FOCUS GROUPS}

To provide the necessary background for the development of the toolkit, in-depth interviews and informal group discussions were conducted with staff from the four collaborating housing authorities about how their agency administers the HCV program. We also conducted focus groups with HCV participants who had moved within the last year to learn more about how they searched for housing and made their housing choice. From these interviews and focus groups, we concluded the following:

- To fit seamlessly into existing programs, the toolkit must be adaptable to different institutional contexts.

- The toolkit should consist of a few technical tools that produce new, individualized information and key messages delivered in a number of different ways to encourage behavior changes.

- For HCV participants, the process of finding housing and navigating the voucher process is a complicated one. Due to large caseloads, housing authorities are unable to provide extensive staff time to help HCV participants; they are on their own when it comes to finding housing.

- When they are getting ready to move, HCV participants are provided with a lot of information from the housing authority intended to help them. It is possible that the amount of information and paperwork could be overwhelming.

- The down side of not finding housing within the allotted time frame (typically 90 to 180 days during the study period, with exceptions of up to 270 days) can be severe; a participant could lose access to the voucher, which may result in homelessness. 
- The anxiety-driven search process can be improvisational and chaotic; nevertheless, a combination of factors results in some degree of prioritization by place for some HCV participants. So, place does matter, at least in some instances. Thus, it makes sense to provide HCV participants with tools that help them search by location.

- While some HCV participants found that they benefitted from moving to locationefficient neighborhoods, what seemed even more relevant were places nested in an individualized network of frequent destinations. Thus, tools that help participants identify personally efficient locations are especially useful.

- The cost of rental housing and the scarcity of rentals during the study period inhibited the ability of voucher holders to live in location-efficient and affordable neighborhoods. If they could not afford the rent, then other kinds of assistance or policies will not help them access location-efficient housing. The toolkit does not assist with addressing this substantial barrier.

\section{THE TOOLKIT}

The toolkit consists of two messaging products (a pamphlet and a six-minute video) and three tools (a guide to using the online application Walk Score Apartment Finder, a "house finding" checklist and a cost comparison worksheet). Key messages are:

- When you choose a place to live, you're choosing more than a safe, affordable space for you and your family. You're also choosing how you will get around, and how much time and money you will spend getting around.

- In our area, transportation costs about $30 \%$ of what families with housing assistance earn each month. For many, that's about as much as your housing costs.

- Unlike housing costs, transportation costs can sneak up on you. Most people know how much they pay for rent because it's paid all at once. But most people don't realize how much they spend on transportation, as the costs are paid gradually.

- What can you do about transportation costs? Think of the places where you go often. Then identify an area where you could get to your regular destinations in a reasonable amount of time and at a reasonable cost. This is your travel zone. Start your search for housing there.

- You may have challenges with finding a place to live, but a housing voucher gives you choices. Consider your transportation options and costs before you make a move.

\section{EVALUATION}

This study uses a pre-test, post-test with control group research design to evaluate the effectiveness of the toolkit. The evaluation did not detect many significant differences between the outcomes of those who said that they remembered seeing the toolkit and those who did not. Those that were significant are as follows:

- Better access to transit in new home: Those who remembered seeing the toolkit moved to places which they found to have easier access to public transit stops by walking, while those who didn’t remember the toolkit moved to places they found have more difficult access. 
- Lower housing costs: Those who remembered seeing the toolkit said that their housing costs decreased as a result of their move, while those who did not remember seeing the toolkit said that their housing costs increased. Both groups said that their transportation costs increased, and the difference between them was not significant.

\section{CONCLUSION}

Thus, the evaluation resulted in little evidence to indicate that the toolkit can help the population of HCV participants in general move to housing with lower transportation costs in a very tight housing market. However, the toolkit might have greater relevance to HCV participants facing a move under different market conditions, when they have more choice about where to live. The toolkit most likely proved useful to some HCV participants (but not enough to show up statistically) during the very tight housing market. The toolkit may be more effective if it were introduced in a different manner, and if accompanied by additional changes in how the HCV program is administered. Finally, the study overall produced interesting new information about how HCV participants make housing choices and the kinds of challenges they experience. 


\subsection{PROBLEM STATEMEMENT AND APPROACH}

\subsection{PROBLEM STATEMENT}

The purpose of this project is to develop and evaluate tools to assist Housing Choice Voucher (HCV) program participants in the Portland metro region with considering transportation needs and options when making decisions about where to live. The project consists of two elements: development of a set of tools in collaboration with four area housing authorities, and an evaluation of the effectiveness of the tools.

Transportation costs are typically a household's second-largest expense after housing and, on average, account for about one-fifth of household spending. Low-income households are especially burdened by transportation costs, with low-income households spending up to two times as much of their income on transportation than higher-income households (Litman, 2013). Thus, reducing transportation costs is likely to have a disproportionately positive effect on the budgets of low-income households, both because of the share of their budgets it claims and because they have little to no discretionary resources to absorb higher transportation costs without impacting their ability to purchase other life essentials, like food and health care. Location-efficient housing can also provide other benefits to individuals, such as reducing the amount of time spent travelling to regular destinations and enabling active living. Societal benefits include reduced energy consumption and reduced greenhouse gas emissions (Location Efficiency Hub, 2016: http://www.cnt.org/projects/location-efficiency-hub). Thus, a toolkit that helps low-income households find location-efficient housing could positively affect their wellbeing in several ways and provide societal benefits as well.

Over the last decade, efforts have arisen to re-conceptualize housing affordability more holistically as a "combined cost of place" known as location affordability. Location affordability integrates transportation costs associated with living in a particular place with housing costs into a single measure typically defined in terms of a percentage of household income (Hickey, Lubell, Haas \& Morse, 2012). A closely related concept is location efficiency, which is concerned with access to employment opportunities, transit and other locational amenities (Fisher et al., 2009; Hass et al., 2008), and is associated with reduced vehicle use and higher levels of active transportation (Ewing \& Cervero, 2010).

This project was initially conceptualized by the four housing authorities in the Portland, OR, metro region: Home Forward (formerly Housing Authority of Portland), Housing Authority of Clackamas County, Housing Authority of Washington County, and Vancouver Housing Authority. Staff from these agencies collaborated to apply for Regional Transportation Options funding from Metro, the regional planning agency and the designated Regional Transportation Planning Organization. With funding in hand, in spring 2013 they selected a team of researchers from Portland State University's Center for Urban Studies to develop tools that their employees could use to assist HCV participants with considering their transportation needs and options 
when deciding where to live. The researchers were also asked to undertake an evaluation of the efficacy of the tools.

In their Request for Proposals, the housing authorities described the problem to be addressed as follows:

Multiple studies...have shown that the Portland metro region is of a scale to be considered one job market and one housing market...yet many low-income households...make residential choices dictated by housing costs alone, choosing to live in seemingly affordable locations far from employment opportunities and other daily needs - and consequently incur high transportation costs and higher overall household expenses.

The housing authorities sought to address the problem by developing a mobility counseling toolkit that provided program participants with information about transportation costs and tools to find and evaluate the associated transportation costs of potential housing options. The tools needed to be in a format that could be easily integrated into the administrative processes of the four housing authorities, each of which had a different approach to interacting with participants. The housing authorities did not have access to additional resources to assist participants with their housing search, such as staff time for in-depth individualized location/relocation counseling, funding for public transit passes or access to transportation to assist participants with visiting potential housing locations.

The housing authorities established the following desired outcomes for the project:

Knowledge

- Increase program participants' awareness of transportation costs and benefits of locationefficient housing choices.

$\underline{\text { Behavior }}$

- Reduce households’ transportation costs.

- $\quad$ Reduce the share of household trips completed by personal vehicles.

- Increase the share of household trips completed by walking, biking, public transit and carpooling.

- Increase the likelihood that participants would consider proximity and costs of travel to frequent destinations when choosing a new home.

From March 2013 through May 2015, the three-member PSU research team and a Project Steering Committee composed of representatives from each of the four housing authorities collaborated closely to produce the toolkit, train housing authority staff in how to use it, develop and refine the evaluation surveys, and administer and analyze the surveys. This report presents the products developed during this process, evaluates their efficacy and summarizes the lessons learned in the process. 


\subsection{THE HOUSING CHOICE VOUCHER PROGRAM, HOUSING MOBILITY AND CHOICE}

On the surface, the purpose of this project may seem straightforward: to develop and evaluate tools to help HCV participants consider transportation costs when they choose where to live. However, imbedded in this effort are a host of assumptions and theories about housing mobility and the choices available to voucher holders. This brief review of relevant literature explores these topics and their relationship to this study ${ }^{1}$.

HCV program and its predecessor, the Section 8 program, are demand-side interventions in the housing market that boost the resources that households with low incomes have to spend on housing. In theory, HCV participants are able to choose housing in the private market instead of being limited to specific housing developments with supply-side subsidies and restricted rents (such as public housing or housing supported by the Low-Income Housing Tax Credit Program), as long as that housing passes a Housing Quality Standard inspection and has rent that falls within program limits. In reality, evidence suggests that HCV participants, while satisfied with the program overall, experience a number of practical constraints that further impinge upon housing choice. The outcome is that voucher holders often live in neighborhoods that are poorer, more racially segregated, and served by schools with lower standardized test scores than the average neighborhood (Basolo, 2013; Scott et al., 2013; Cunningham \& Droesch, 2005; Devine, Gray, Rubin \& Taghavi, 2003; Pendall, 2000).

Housing mobility programs are intended to address this limitation by expanding the range of neighborhoods that households with low incomes and housing subsidies access. Mobility programs are about helping people find and afford high-opportunity neighborhoods, places with physical and social assets, and environments believed to support household advancement (Scott et al., 2013). A robust array of research and program resources related to mobility and mobility programs can be found on the following website maintained by the HousingMobility.org Partners (Poverty and Race Research Action Council, ACLU of Maryland, The Aspen Institute, Inclusive Communities Project and Housing Choice Partners): http://www.housingmobility.org/

The first mobility program to receive substantial research attention was Gautreaux, a natural experiment that resulted from court-ordered desegregation of Chicago Housing Authority households to suburban neighborhoods with lower concentrations of racial minorities. This was followed by Moving to Opportunity, a HUD-sponsored national demonstration project that used a five-site, quasi-experimental design to analyze the individual and household benefits of moving from high- to low-poverty neighborhoods.

Ultimately, research studies on the outcomes of these and other mobility programs have found mixed results, with the most promising outcomes occurring in participants' sense of safety, adult mental health, and female teenage mental health and life course outcomes. For example, Basolo (2013) found that, while participants in Orange County, CA, were able to move to areas with lower poverty rates and better schools, these conditions did not translate to better outcomes for movers than non-movers. These mixed results led commentators DeFilippis (2013) and

\footnotetext{
${ }^{1}$ This literature review is drawn from a manuscript submitted by the authors in 2015 to Housing Policy Debate for a special issue on location-efficient housing.
} 
Venkatesh (2013) to question the wisdom of attempting to solve social problems with spatial solutions while not addressing underlying structural limitations in housing choice and labor markets that households with low incomes experience.

In contrast to mobility studies dealing with relocation to broadly defined high-opportunity neighborhoods, research addressing location affordability deals with a specific kind of access and mobility: movement to neighborhoods where households are likely to have lower combined housing and transportation costs. It is predicated on the understanding that households will have more resources left over to pay for other life essentials, discretionary spending and savings if they can find a location with lower combined housing and transportation costs. For HCV households, the emphasis is on reducing transportation costs because a Housing Choice Voucher has the effect of moderating the impact of the cost of housing on the share of income that the tenant pays at initial lease-up. Unlike mobility related to accessing high-opportunity neighborhoods or places with lower concentrations of poverty, mobility related to location affordability within the HCV program is concerned with unambiguous, tangible outcomes that have immediate benefits for households: lower transportation costs and a greater share of household income available for other purposes.

It would seem logical, then, that HCV households would choose to locate in neighborhoods with relatively low transportation costs. Research focused on neighborhood preferences suggests that across income levels there is a strong preference for location-efficient housing (Levine \& Frank, 2007). But housing choices, particularly those by HCV participants, often involve complex trade-offs, limited information and price constraints. For example, Clampet-Lundquist (2003) found that the majority of women with low incomes whom she studied based their moves on the maintenance of personal safety networks rather than neighborhood characteristics and factors associated with access to opportunity. Indeed, Skobba and Goetz (2013) dismiss the assumption that people living in poverty make housing decisions in a way that places neighborhood above all other concerns.

The conditions under which decisions about moves are made are also relevant to understanding constraints on choice. Clark (2010) found that a majority of moves by low-income households resulted from push factors such as family union dissolution, evictions, household conflict and overcrowding. In a study of the moves of 47 low-income households in the Minneapolis-Saint Paul region, Skobba and Goetz (2013) found that moves conformed to one of three types: (1) forced moves (participants did not have a choice, and the move was not planned); (2) discretionary moves (participants had control over the move, and it was planned); and (3) a combination of push and pull factors (e.g., the desire to take care of an elderly relative). Forced moves, a majority of all such moves, involved quick and haphazard searches to find somewhere to live. For those who had options, Skobba and Goetz found personal relationships were the primary driving force in the residential choices they made.

Finkel and Buron (2001) studied factors affecting the HCV participant lease-up rates of a sample of 48 larger metropolitan housing authorities. They found that lease-up rates were lower in areas with tight rental housing markets. Jurisdictions with protections for discrimination against households using a HCV as a source of rent payments experienced an improved likelihood of HCV participants leasing a home within the search time allotted. Local program design features 
that had a positive impact on lease-up rates included how HCV orientations were conducted, housing search assistance and outreach to potential landlords.

In summary, the constraints on housing choice that HCV participants experience appear to fall into three interrelated categories. Some appear to be primarily programmatic (imbedded within the design and implementation of the HCV program itself); others are primarily structural (related to the political economy of a housing market in a specific area); and still others appear to be primarily related to the circumstances of individual participants. These three kinds of challenges, and how they relate to this study's participants, are discussed in Section 2 of this report.

\subsection{APPROACH}

This section contains a brief overview of the approach to undertake the two elements of the project, Toolkit Development and Evaluation. More detailed information about the research design and methods can be found in Sections 2 and 3 of this report. Appendix A provides a timeline for the project, which began in Spring 2013 and concluded in Fall 2015, a period of 33 months.

The first steps associated with the toolbox's development involved learning about the experiences of HCV participants who had recently moved, and exploring the main policies, practices and organizational culture surrounding the administration of the HCV program by each of the participating housing authorities. Research methods included interviews with housing authority staff, focus groups with HCV participants and a review of documentary data. Next, existing tools, such as HUD’s My Transportation Cost Calculator and Housing Affordability Index (http://www.locationaffordability.info/) were examined. Questions related to the purpose, content and format of the tools were discussed at length at project Steering Committee meetings, and at meetings with program staff who interact with participants on a regular basis. Particular attention was paid to three concerns: 1) an appreciation of the detailed knowledge that many HCV participants have with transportation options and limitations in their existing neighborhoods; 2) respect for the ability of program participants to make difficult decisions when faced with scarcity; and 3) the need to provide tools that were simple and easy to use. The final toolkit consisted of printed materials and a brief video.

The evaluation involved a pre-test, post-test design with a control group. For the intervention group, pre-test surveys about transportation attitudes and behaviors were administered before they were exposed to the tools or moved, and then the tools were provided. The post-test survey was administered approximately one to two months after their move to capture information about attitudes and behaviors in their new home. The same survey sequence and timing were followed for the control group, but they did not receive the toolkit. Challenges encountered with fully deploying the tools are discussed in subsequent sections of this report. The "change difference" - a comparison of the differences in responses between Survey 1 (pre-test) and Survey 2 (post-test) for the Control Group and the Intervention Group-was examined to determine whether those who had been exposed to the toolkit had different outcomes than those who were not exposed to it. Data collection for the evaluation occurred during 2014 and 2015. 
One of the less conventional aspects of this project is the fact that the same project team participated in the development of the tools and their evaluation. While this dual role permits a more integrated approach to project management, it raises the potential risk of bias in the evaluation. This concern was addressed in several ways. First, the team based the survey on an existing one that had been used and vetted for a previous research project regarding location preferences of movers undertaken by Adkins. Second, the distribution and collection of the anonymous survey was managed by the housing authorities (not the researchers), and researchers asked that all HCV participants who moved during the time period of the study were invited to participate. Third, the questionnaire yielded quantitative data. Fourth, the research team was conscious of the potential for bias and strove to avoid it throughout the project.

Ultimately, this project is a mixed-methods case study about the experiences of HCV participants with finding location-efficient housing in the Portland metro region during the 2014-2015 time period. It utilizes qualitative data about the experiences of program participants seeking housing, and quantitative data about their transportation preferences and behaviors before and after a move. Most importantly, it is a study that occurs within a particular context that includes the policies and practices of four housing authorities on one hand, and the impact of the housing market on the participants' housing choices on the other. This context is relevant to the study's findings. It is to an exploration of this context that this report now moves. 


\subsection{CONTEXT FOR THE STUDY}

The literature indicates that there are three interrelated constraints on housing choice that participants experience: structural (related to the housing market and the availability of housing from which to choose); programmatic (related to the federal HCV program and the ways in which local housing authorities implement it); and individual (related to the circumstances of specific people and households seeking housing). This chapter examines the context in which participants searched for and located housing during the study period by analyzing each of these constraints. Local housing market data and information from interviews with housing authority staff are used to examine structural constraints. The institutional context is explored using information about the HCV program nationally, documentary data provided by the housing authorities and information from key informant interviews with staff. The research team used focus groups to explore the experiences of participants who had recently moved within the region to better understand both personal factors influencing housing choice, and also how institutional and structural factors affected their daily lives, their housing options and the choices that they made.

The initial purposes of this analysis were practical: to develop tools that were crafted to the needs and interests of participants in ways that were useful to them, and to ensure that the tools fit into the existing work flow and processes of the four participating housing authorities. As the project progressed, it became apparent that this initial contextual analysis also served a second purpose: it supported a more robust interpretation of the evaluation's results.

\subsection{THE PORTLAND METRO REGION HOUSING MARKET}

The dynamics of the regional housing market have a strong impact on this project because they affect how much choice voucher holders have in finding a place to live. High demand for rental housing relative to supply typically leads to escalating rents, sometimes higher than what voucher holders can afford. In addition, property owners can set their own screening standards for applicants, which, in some cases, may be difficult for HCV participants to meet. As a result, voucher holders may respond to a tight market by having a greater tendency to take the first acceptable home for which they are approved rather than optimizing their search.

When the housing authorities originally conceived of the project, vacancy rates were high enough to ensure that participants in some areas were likely to have choices about where to live if they moved. Table 2.1 below shows that estimated vacancy rates in the three suburban counties ranged from $5.1 \%$ to $8.2 \%$ in 2010. However, by 2014, the year in which the tools were made available to participants, the vacancy rate for multifamily rental housing had dropped to $1.8 \%$ to $3.1 \%$ in the jurisdictions served by the four housing authorities. A $5 \%$ vacancy rate is often considered to be "full occupancy" because of the impact of unit turnovers between renters. 
Table 2.1: Rental Vacancy Rate Estimates, 2010 - 2014

\begin{tabular}{l|l|l}
\hline County & $\mathbf{2 0 1 0}$ & $\mathbf{2 0 1 4}$ \\
\hline Multnomah County, Oregon & $3.7 \%$ & $1.8 \%$ \\
\hline Clackamas County, Oregon & $7.3 \%$ & $3.1 \%$ \\
\hline Washington County, Oregon & $5.1 \%$ & $2.3 \%$ \\
\hline Clark County, Oregon & $8.2 \%$ & $2.4 \%$ \\
\hline
\end{tabular}

Source: Census Bureau, Comparative Housing Characteristics, 2014 American Community Survey 1 year estimates.

Figure 2.1 compares changes in vacancy rates in sub-areas within the region using data from a locally conducted survey. Although market conditions vary across the region, vacancy rates were below 5\% in most areas at the beginning of the study in spring 2013. A year later, the vacancy rates were close to 3\% in most areas and remained low through spring 2015. In spring 2013, housing authority staff from the three Oregon counties said that rental housing available to voucher holders was in short supply, especially in places with walkable neighborhoods, good transit access and/or good quality schools. However, staff from Vancouver Housing Authority in Clark County, WA, reported an ample supply of rental housing, especially single-family houses for rent in the wake of housing foreclosures resulting from the prior recession. By summer 2014, the situation had changed, and all housing authority staff reported that only a short supply of housing was available to their program participants.

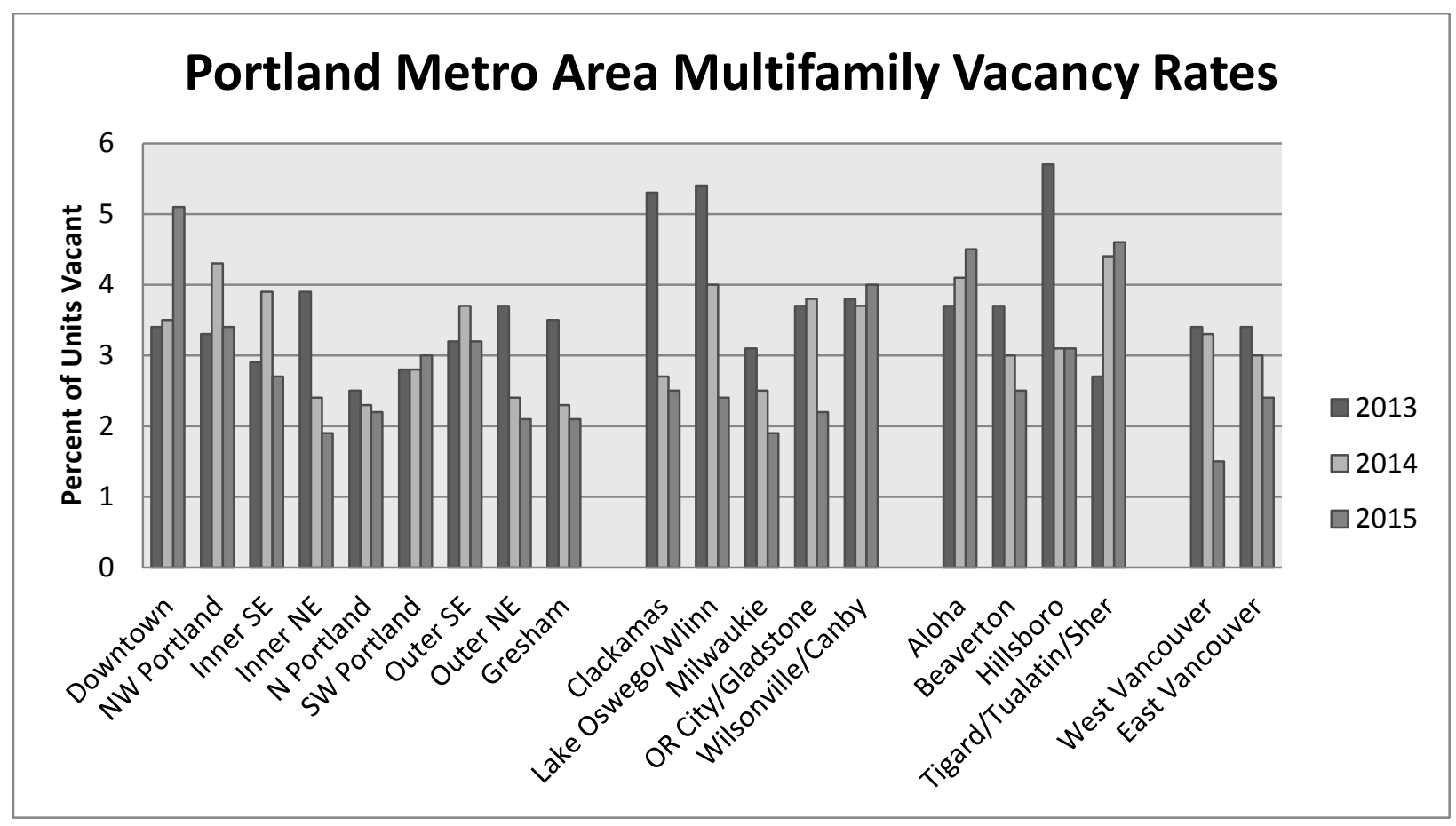

Source: Multifamily NW, as reported in Center for Real Estate Quarterly, Portland State University, Volume 7, No. 2, Spring 2013; Volume 8, No.2, Spring 2014 and Volume 9, No. 2, Spring 2015.

Figure 2.1: Multifamily Vacancy Rate Estimates, 2013-2015 
Low vacancy rates have a double impact on HCV participants seeking housing. First, it means that there are few housing options from which to choose. While this is true for all home-seekers, it has a particularly limiting effect on HCV participants when combined with property owners screening criteria. Until July 2014, property owners in Oregon were able to legally refuse to accept a HCV as a form of rent payment, thus ruling out the possibility of renting to any HCV participant. While Oregon landlord/tenant law changed in July 2014, landlords still set other application screening criteria (e.g., minimum income relative to rent or minimum credit scores) that prevent many participants from qualifying.

Second, low vacancy rates typically drive up rents. When demand exceeds supply, property owners can charge more. This means that a greater share of rental units may move beyond the means of HCV participants to rent.

The impacts of a tight market are reflected in Figures 2.2 through 2.4 below. Figure 2.2 shows that the share of participants who successfully found and leased housing generally decreased from 2011 to 2014-15 for two of three housing authorities, with Vancouver's rate fluctuating between 92 and 99 percent.

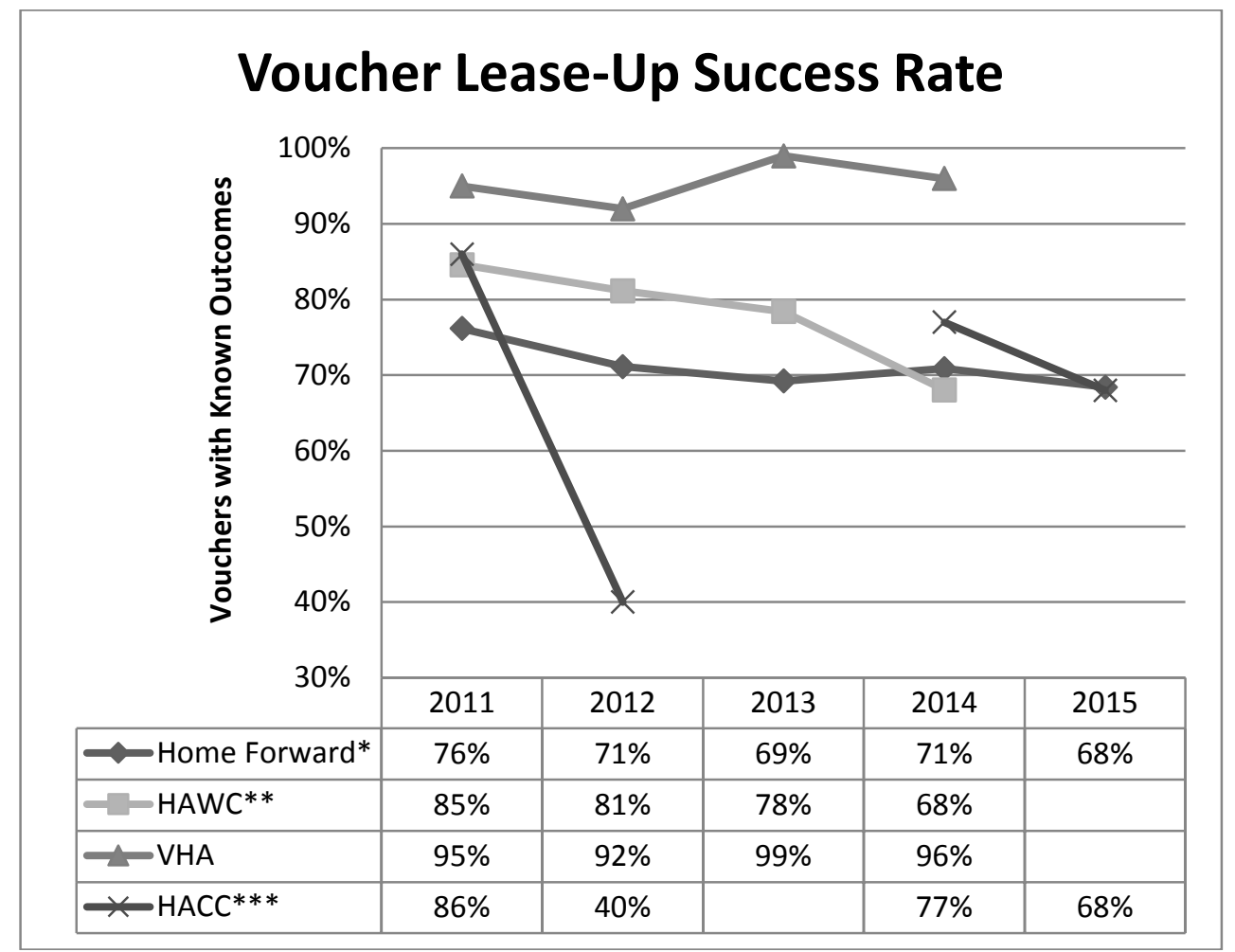

Source: Home Forward, Housing Authority of Washington County and Vancouver Housing Authority, 2015

*Data for Home Forward only reflects outcomes of program participants who moved

**In mid-June 2014, approximately 100 issued vouchers were expired by HAWC due to a funding shortage. This inflates the number of unsuccessful outcomes during 2014 for HAWC

***HACC stopped issuing vouchers due to Sequestration. This may have affected the lease up rates for 2012 and is the reason why no data is provided for 2013.

Figure 2.2: Voucher Lease-up Success Rates, 2011-2015 
Figure 2.3 shows that the length of time that three categories of voucher households- - those moving within the service area, new program participants pulled from the waiting list, and those who "ported in" to Home Forward's service area from a different jurisdiction-increased from 2010 through mid-year 2015.

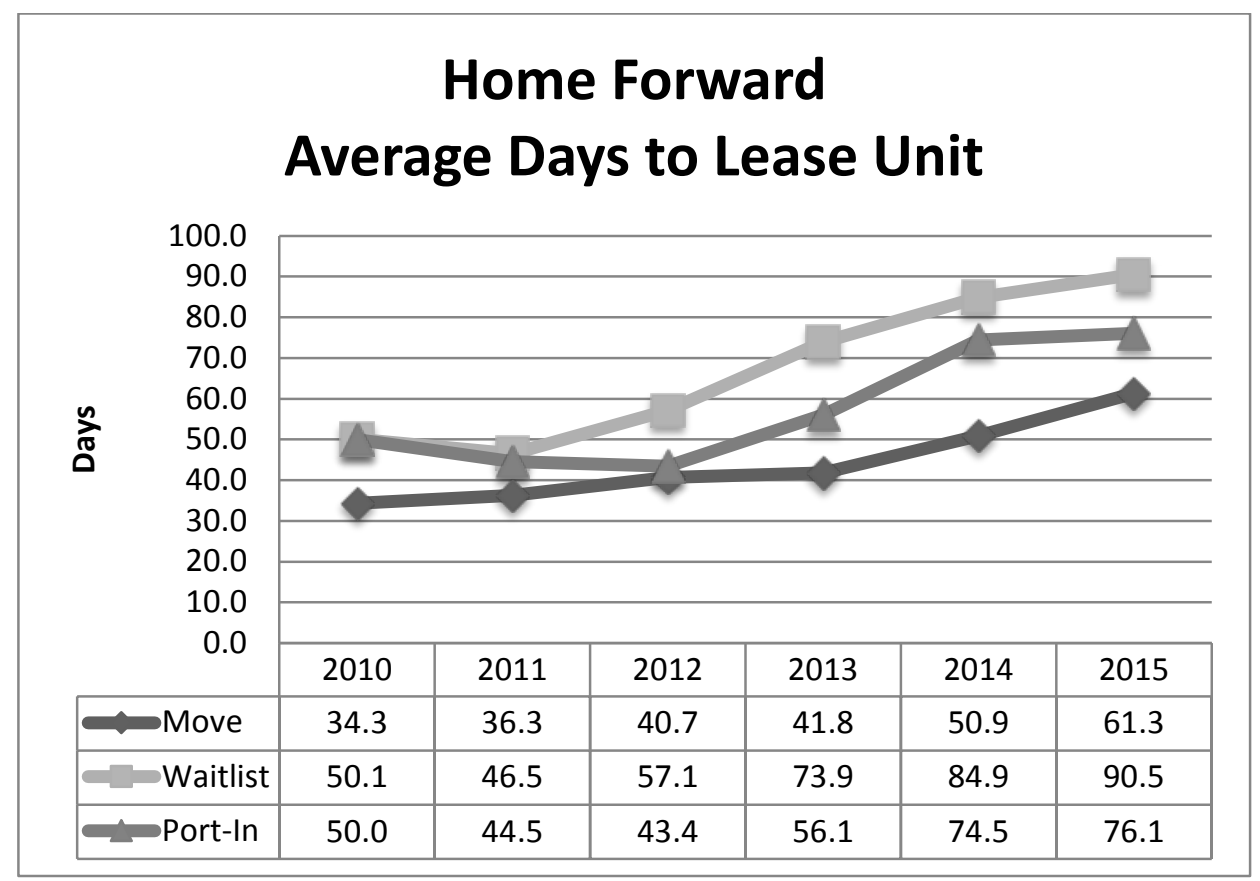

Source: Home Forward, 2015

Figure 2.3: Home Forward, Average Days to Lease Unit, 2010-2015

Finally, Figure 2.4 depicts a similar trend for voucher holders with the Housing Authority of Washington County. The share of program participants who were able to lease their home within 30 days decreased, while those who took 61 days or more increased. 


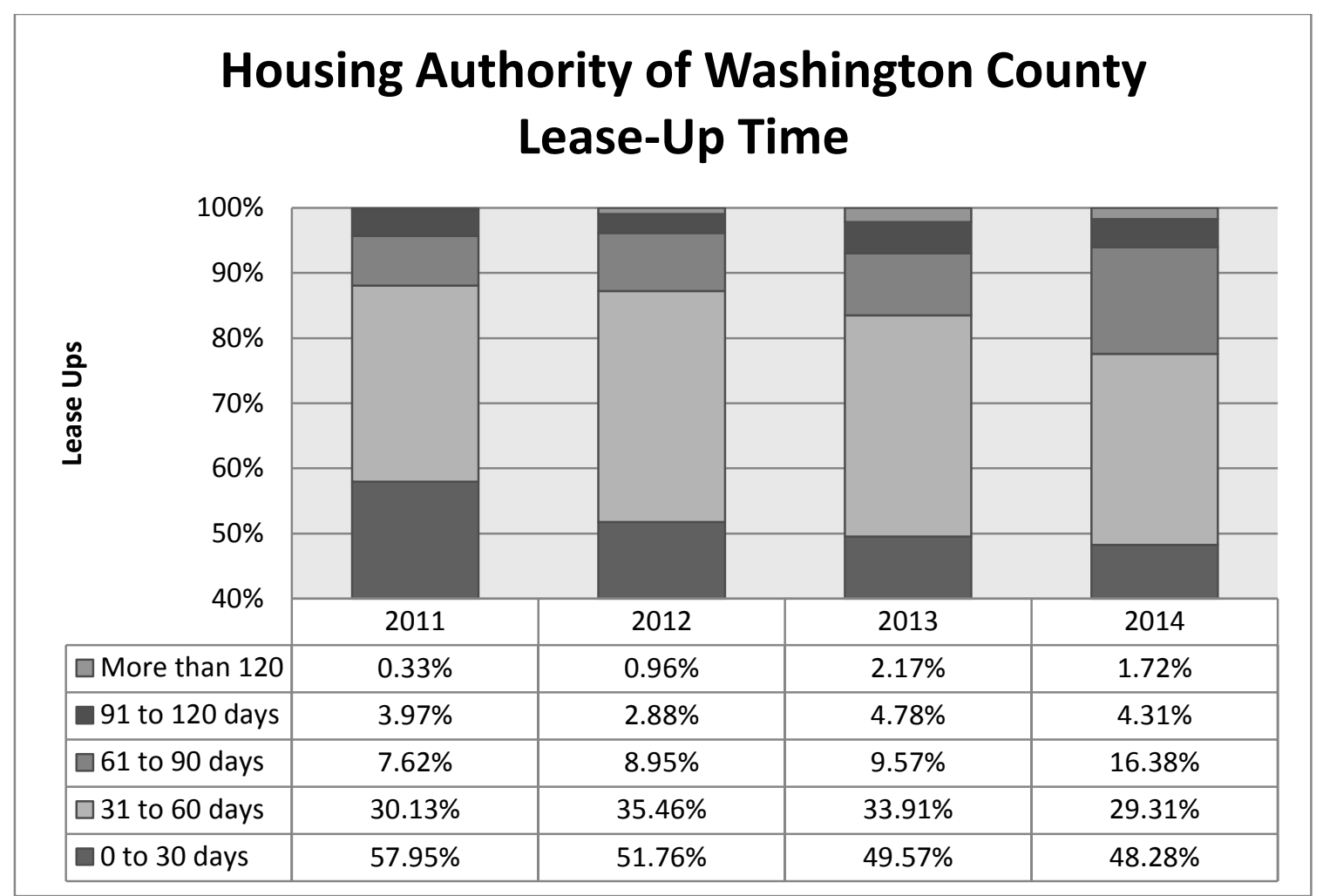

Source: Housing Authority of Washington County, 2015

Figure 2.4: Housing Authority of Washington County Lease-up Time, 2011-2014

During this study period, participants faced severely constrained housing choices. It was difficult for voucher holders to find affordable housing anywhere in the region, but especially in compact, walkable, dense, close-in Portland neighborhoods or in higher-income areas.

\subsection{INSTITUTIONAL CONTEXT}

\subsubsection{The Housing Choice Voucher Program}

The HCV program is currently the largest source of low-cost, subsidized housing in the U.S. Unlike public housing and homes built with Low-Income Housing Tax Credits and other supplyside programs, it does not usually lead to the creation of new housing units ${ }^{2}$. Instead, vouchers provide rent assistance to participating households, who typically have incomes below 50\% of area median, adjusted for household size. Program participants find their own housing in the private or nonprofit housing market. The HCV program is built on the concept of providing location and housing choice instead of restricting participants to particular housing developments.

\footnotetext{
${ }^{2}$ The exception are project-based vouchers, which are assigned to specific projects for designated periods of time and are used to promote the affordability of units while providing a reliable revenue stream for the property owner. Sometimes project-based vouchers are assigned to existing buildings, but in other cases they are used to help finance the creation of new housing units.
} 
The U.S. Department of Housing and Urban Development (HUD, n.d. ${ }^{3}$ ) provides the following description of how the program works:

The housing choice voucher program places the choice of housing in the hands of the individual family. A very low-income family is selected by the Public Housing Authority (PHA) to participate and is encouraged to consider several housing choices to secure the best housing for the family needs. A housing choice voucher participant is advised of the unit size for which it is eligible based on family size and composition.

The housing unit selected by the family must meet an acceptable level of health and safety before the PHA can approve the unit. When the voucher holder finds a unit that it wishes to occupy and reaches an agreement with the landlord over the lease terms, the PHA must inspect the dwelling and determine that the rent requested is reasonable.

The PHA determines a payment standard that is the amount generally needed to rent a moderately-priced dwelling unit in the local housing market and that is used to calculate the amount of housing assistance a family will receive. However the payment standard does not limit and does not affect the amount of rent a landlord may charge or the family may pay. A family which receives a housing voucher can select a unit with a rent that is below or above the payment standard. The housing voucher family must pay $30 \%$ of its monthly adjusted gross income for rent and utilities, and if the unit rent is greater than the payment standard the family is required to pay the additional amount. By law, whenever a family moves to a new unit where the rent exceeds the payment standard, the family may not pay more than 40 percent of its adjusted monthly income for rent ${ }^{4}$.

The PHA calculates the maximum amount of housing assistance allowable. The maximum housing assistance is generally the lesser of the payment standard minus 30\% of the family's monthly adjusted income or the gross rent for the unit minus $30 \%$ of monthly adjusted income.

For this project, housing authority staff helped explain how the program works and shared insights on the micro-incentives and disincentives that program rules create for program participants and their choice of housing. These are explored below.

\subsubsection{Four Housing Authorities in the Portland Metro Region}

Four housing authorities in the Portland region initiated this project: Home Forward, which serves Multnomah County, including the city of Portland; the Housing Authority of Clackamas County; Washington County Housing Authority; and Vancouver Housing Authority, which serves Clark County, WA. Home Forward and Vancouver Housing Authority are Moving to

\footnotetext{
${ }^{3}$ See

http://portal.hud.gov/hudportal/HUD?src=/program_offices/public_indian_housing/programs/hcv/about/fact_sheet for additional information.

${ }^{4}$ Moving to Work housing authorities can set a standard different than the $30-40 \%$ indicated above. For example, Home Forward HCV participants may pay up to $70 \%$ of income for housing costs.
} 
Work PHAs. HUD established the Moving to Work (MTW) demonstration program to provide opportunities for housing authorities to create locally designed strategies that achieve financial efficiency, promote employment self-sufficiency and increase housing choices. In return, MTW PHAs are exempted from many federal public housing and HCV regulations, and get more flexibility with how they use their federal funds. Table 2.2 below profiles the Housing Choice Voucher Program of the four Portland metro housing authorities.

Table 2.2: Profile of Housing Voucher Programs in Portland Metropolitan Area 2012

\begin{tabular}{l|l|l|l|l}
\hline Characteristic & Home Forward & $\begin{array}{l}\text { Housing } \\
\text { Authority of } \\
\text { Washington } \\
\text { County }\end{array}$ & $\begin{array}{l}\text { Vancouver } \\
\text { Housing } \\
\text { Authority }\end{array}$ & $\begin{array}{l}\text { Housing } \\
\text { Authority of } \\
\text { Clackamas } \\
\text { County }\end{array}$ \\
\hline Total contracted vouchers & 8,159 & 2,635 & 2,313 & 1,623 \\
\hline $\begin{array}{l}\text { Share of households (HH) who } \\
\text { moved in past year }\end{array}$ & $7 \%$ & $7 \%$ & $6 \%$ & $6 \%$ \\
\hline $\begin{array}{l}\text { Ave \# of months since HH moved } \\
\text { in }\end{array}$ & 91 & 91 & 77 & 83 \\
\hline $\begin{array}{l}\text { Ave HH contribution to rent and } \\
\text { utilities per month }\end{array}$ & $\$ 345$ & $\$ 320$ & $\$ 337$ & $\$ 347$ \\
\hline $\begin{array}{l}\text { Share of HH where wages are } \\
\text { major source of income }\end{array}$ & $18 \%$ & $16 \%$ & $19 \%$ & $21 \%$ \\
\hline $\begin{array}{l}\text { Percentage of local median HH } \\
\text { income }\end{array}$ & $18 \%$ & $21 \%$ & $21 \%$ & $20 \%$ \\
\hline $\begin{array}{l}\text { Share of HH who have extremely } \\
\text { low income }\end{array}$ & $87 \%$ & $83 \%$ & $83 \%$ & $83 \%$ \\
\hline $\begin{array}{l}\text { Share of HH who are people of } \\
\text { color (minorities) }\end{array}$ & $48 \%$ & $31 \%$ & $22 \%$ & $14 \%$ \\
\hline $\begin{array}{l}\text { Share of HH who are female- } \\
\text { headed }\end{array}$ & $70 \%$ & $74 \%$ & $74 \%$ & $80 \%$ \\
\hline $\begin{array}{l}\text { Share of HH who are female head } \\
\text { with children }\end{array}$ & $35 \%$ & $34 \%$ & $31 \%$ & $39 \%$ \\
\hline $\begin{array}{l}\text { Share of HH age 61 and younger } \\
\text { with disabled head of HH or spouse }\end{array}$ & $40 \%$ & $54 \%$ & $54 \%$ & $43 \%$ \\
\hline $\begin{array}{l}\text { Share of HH age 62 and older with } \\
\text { disabled head of HH or spouse }\end{array}$ & $72 \%$ & $69 \%$ & $86 \%$ & $57 \%$ \\
\hline $\begin{array}{l}\text { Share of HH with head of HH age } \\
62 \text { and older }\end{array}$ & $21 \%$ & $22 \%$ & $32 \%$ & $22 \%$ \\
\hline $\begin{array}{l}\text { Share of HH with head of HH age } \\
85 \text { and older }\end{array}$ & $1 \%$ & $1 \%$ & $3 \%$ & \\
\hline Source US Depan & & \\
\hline
\end{tabular}

Source: US Department of Housing and Urban Development, Picture of Subsidized Households (2012)

Interviews with the housing authorities were conducted to gain information about how each currently administers the HCV program, so that the mobility tools could be constructed to be context-sensitive and built upon current practices and processes. The interviews lasted two to three hours, and were conducted onsite with key stakeholder staff at each of the four housing authorities in May 2013 by Primary Investigator Andrée Tremoulet and Arlie Adkins. Staff also provided written program materials to assist with the analysis.

Interview participants were provided with a list of topics to be discussed and asked to collect relevant written material prior to the meeting (Appendix B-1). The research team took notes, collected written information and developed a summary of each interview. The research team 
reviewed the material, identified six key themes or topic areas, and noted variations among the housing authorities with respect to these themes. The research team then considered how these findings might affect the development and deployment of the mobility tools and the evaluation of their effectiveness. These recommendations were reviewed with the Steering Committee, and the research design and toolkit concepts were refined based on this information.

The six principal themes are as follows:

- Potential Sources of Program Participants for Mobility Tool Project

- Current Housing Opportunities

- Opportunity-Rich, Location-Efficient Housing

- Participant Choices Around Moving

- Process for Moves

- Relevant Housing Authority Policies

Appendix B-2 presents a summary of these themes in table form. Each theme is discussed below.

\subsubsection{Potential Sources of Mobility Program Participants}

In recent years, federal allocations to housing authorities nationally have declined, resulting in increased pressure and larger caseloads for staff. In 2013, sequestration at the federal level led to further changes in local programs and staffing levels. One of the direct effects of sequestration was that three of the four housing authorities stopped issuing vouchers to new participants from their waiting lists when existing vouchers were returned by households leaving the program (wait list pulls). This significantly impacted the design of the Mobility Counseling Toolkit Project, as originally the tools were to be provided to new participants during the orientation, when they were learning how to navigate the program and find housing.

The other group of participants who potentially could use the tools consisted of current HCV participants who were moving from their existing home to a new one (transfers or moves). In 2012, the housing authorities reported there were approximately 1,500 HCV households who moved within the region. While housing authority staff expected fewer moves in 2013 than in 2012 due to a tight housing market, movers were found to represent a potential population who could participate in this project in lieu of the planned population. While movers are more experienced with navigating the rules of the program than wait list pulls or other new participants, the external challenges and constraints in finding housing were seen as being similar to those experienced by new voucher holders.

\subsubsection{Views on Housing Opportunities for HCV Participants Movers in 2013}

As previously indicated, the rental housing market in 2013 was beginning to become very competitive, with vacancy rates falling below $5 \%$ in most areas. Housing authority staff noted that some areas of the region-especially in older, walkable neighborhoods well-served by transit and with a diversity of land uses-were especially difficult for HCV participants to access. 
Home Forward staff indicated that, in Multnomah County, many voucher holders lived east of I205. They reported that it was hard for participants to find housing in close-in Portland neighborhoods. The most popular places for families with vouchers were reported to be along frequent bus and MAX lines in Gresham and other cities in east Multnomah County. Access to services and transit makes downtown Portland a desirable place for people with disabilities and older adults, and there are several senior and disabled subsidized high-rise projects in the area, along with high-cost housing.

Housing Authority of Clackamas County staff said that approximately $40 \%$ of voucher holders lived in one city-Milwaukie-because it offered good schools and services; however, it was not a major source of employment. Oregon City and Gladstone were also said to be popular. Wilsonville, a major source of jobs for the county, had an increase in households utilizing vouchers in 2012. Approximately 15\% to $20 \%$ of Clackamas County HCV participants lived in apartment complexes financed in part through the Low-Income Housing Tax Credit program.

In Washington County, a combination of low vacancy rates and high rents was said to make finding housing difficult. A large share of voucher holders lived in areas near light rail.

Vancouver Housing Authority indicated that the supply of housing available to voucher holders was adequate in Clark County. Their participants usually could find housing and often had choices about where to live. As mentioned previously, an oversupply of single-family, detached housing was built in Clark County during the housing boom, and some of those units entered the rental housing market.

After a year, voucher holders can move from housing in the geographical area covered by their housing authority to the service area of another housing authority. This is called porting ${ }^{5}$. The term port-ins refers to voucher holders who move into a housing authority's service area, and the term port-outs refers to voucher holders moving out of a housing authority's service area ${ }^{6}$. A higher ratio of port-ins to port-outs represents a net inflow of voucher holders. It is interesting to note that Vancouver Housing Authority and Housing Authority of Washington County have higher ratios of port-ins to port-outs. While it is not known what underlying conditions actually gave rise to this outcome, it is worth noting that Washington County is perceived by housing authority staff as being a place with employment opportunities and lower-cost housing than inner-Portland neighborhoods. Clark County is perceived as being a place with more abundant housing in an affordable price range, and where even single-family homes are within reach of some voucher holders.

In summary, housing authority staff reported that it was very difficult for HCV participants to find affordable, close-in housing in Portland, or in higher-income areas like Lake Oswego or West Linn at the beginning of this project. As it progressed, the housing market became more constrained throughout the region.

\footnotetext{
${ }^{5}$ Port-ins and port-outs are not included in the estimate of 1,500 moves in the region in one year.

${ }^{6}$ Home Forward and the Housing Authority of Clackamas County have an agreement in which voucher holders may choose to live in the service area of either housing authority and follow the rules of that housing authority; this does not count as porting.
} 


\subsubsection{Opportunity-Rich, Location-Efficient Housing}

Given that a goal of this project is to assist voucher holders with choosing housing that minimizes transportation costs, the research team explored the concept of opportunity-rich, location-efficient housing with staff at each of the participating housing authorities.

Home Forward staff indicated that the most location-efficient housing for older adults and disabled individuals needing services was likely found in downtown Portland and in nearby, close-in neighborhoods. For families and working adults, the most location-efficient, resourcerich housing was likely found in low-poverty areas in inner NW, NE and SE neighborhoods. Accordingly, Home Forward had adopted a multiple-tier, payment standard approach that provided households who were able to find housing in designated higher-cost, lower-poverty areas with a larger subsidy. But the majority of voucher holders lived outside these designated areas. Staff said that the principal barriers preventing participants from living in the designated areas were high rents, the lack of available rental housing and landlords' ability to refuse applicants with a voucher (a state policy which changed in Oregon later during the project period).

The Housing Authority of Clackamas County developed Opportunity Maps to analyze which areas provide access to a quality environment and services needed by participants. The maps use a "heat map" approach to depicting areas of low to high educational, economic, health care, transportation opportunity and neighborhood quality ${ }^{7}$. The areas with highest overall access to opportunity were found in neighborhoods in Milwaukie, the unincorporated place of Clackamas (near Clackamas Town Center), Oregon City and Lake Oswego. The Housing Authority of Clackamas County adopted a two-tier payment standard to help households afford housing in the cities of Lake Oswego and West Linn, with higher payment standards for these cities. Staff reported that the shortage of affordable rental housing in these two cities posed a significant barrier. Staff also indicated that convenient transit service was not uniformly available throughout the county, and that many people owned cars to get around.

Washington County also developed Opportunity Maps ${ }^{8}$. These maps show access to public transportation, services, a healthy environment and quality schools. There is a single payment standard for Washington County. The Housing Authority of Washington County staff indicated that the most opportunity-rich, location-efficient housing is likely found near MAX stops, the Sunset Corridor and bus routes.

Vancouver Housing Authority staff indicated that it was difficult to identify places in Clark County that were both opportunity-rich and well-served by transit. Higher-income neighborhoods tended to be exclusively residential and lack convenient access to key services like grocery stores that people need on a regular basis. They noted that the county health department had begun a process of mapping the social determinants of health that is based on concepts similar to Opportunity Maps.

\footnotetext{
${ }^{7}$ See http://www.clackamas.us/housingauthority/opportunitymaps.html.

${ }^{8}$ See http://www.co.washington.or.us/CommunityDevelopment/Planning/consolidated-plan-2010-2015-opportunitymaps.cfm.
} 
Thus, development patterns and transit access varies significantly across the four-county area, giving rise to different landscapes of opportunity. Additionally, what constitutes opportunityrich, location-efficient housing varies from one individual to the next, depending on a range of factors including his/her network of needed goods and services, stage in life, ability/mobility, and network of friends and family.

Given this variability among counties and individuals, this project does not attempt to operationalize a generalized concept of “access to opportunity” or "location efficiency." Instead, it focuses on an individualized approach-one that is customized to the needs and wants of the individual and household. Thus, an ideal tool to include in the toolkit is one that enables each participant to identify geographic areas in which to search for housing based on destinations that he or she visits regularly, instead of a tool that promotes searches in pre-determined opportunityrich or location-efficient areas. In other words, this project is based on a concept of "personally efficient housing locations," rather than on more generic concepts of location-efficient or opportunity-rich neighborhoods.

\subsubsection{Participant Choices about Moving}

At all four housing authorities, staff indicated that participants move either by choice or because they are forced to move because of a discontinuation of their lease (eviction or no cause termination). Reasons why participants move include a desire to find a better or less expensive unit, a change in their household size, a job change, or problems with the landlord. According to staff from all four housing authorities, most voluntary movers have identified where they want to move (the complex and/or the unit) before they contact the housing authority to begin the process of changing location. Many of those moving involuntarily will not have chosen a place before contacting the housing authority, but are likely to be anxious to find a new place and feel that they cannot afford to be selective about housing. Some involuntary movers have negative rental histories, poor credit or other barriers to finding a new place to live.

Staff from all four housing authorities conducted a survey of movers for approximately two and half weeks in July 2013 to find out how many households were moving voluntarily, and how many had not selected a place to live when they initiated contact with the housing authority about moving. Approximately 36\% of the 110 households surveyed were voluntary movers who were undecided about where they wanted to live when they first contacted the housing authority for assistance. These are the kinds of participants for whom a location-efficient housing toolkit would be most useful. The table below shows the results of this informal survey.

Table 2.3: HCV Participants’ Reasons for Moving

\begin{tabular}{l|l|l|l}
\hline Public Housing Authority & All Movers & $\begin{array}{l}\text { Tenant Gave Notice } \\
\text { and Was Undecided } \\
\text { About New Destination }\end{array}$ & \begin{tabular}{c}
$\%$ \\
\hline Housing Authority of Clackamas County
\end{tabular} \\
\hline Vancouver Housing Authority & 11 & 2 & $18 \%$ \\
\hline Home Forward & 5 & 1 & $20 \%$ \\
\hline Housing Authority of Washington County & 57 & 22 & $39 \%$ \\
\hline Total & 37 & 15 & $41 \%$ \\
\hline
\end{tabular}

Source: Convenience Sample of Movers. Data collected by Portland area housing authorities, 2013 
Three of the four housing authorities indicated that they maintained listings of private housing for rent with landlords who have indicated that they will accept HCV participants. Clackamas County and Home Forward updated their listings weekly. Both posted their listings online and made printed copies available in their office. Washington County listings were updated in "real time" because landlords were able to update their own listings; they were available online and in hard copy in the office. Vancouver Housing Authority did not maintain a list of units but instead referred participants to Gosection8.com, a national listing service available to landlords. All housing authorities provided links to third-party listing services (e.g., craigslist.com) online and/or in printed materials.

Thus, from these interviews we learned of two potential concerns that affect how movers are likely to be to receiving information about finding location-efficient housing. The first concern is that many movers may be moving not out of choice, and thus may be concerned about their ability to find another place to live. Housing authority staff indicated that these movers were likely to take the first place they could find rather than shopping around. The second concern is that many of those who do move by choice may already have a place in mind when they contact the housing authority and are exposed to the tools. This information allowed the research team to include questions in the survey to identify participants who move voluntarily and without a particular destination in mind when they begin the search process.

\subsubsection{Process for Moves}

The U.S. Department of Housing and Urban Development (HUD) permits each housing authority to develop its own procedures for working with participants who are moving, as long as HUD requirements about notifications, certifications, timelines and related matters are met. Thus, each of the four housing authorities developed distinctly different pathways with differing amounts and types of staff contact for their participants to traverse. Home Forward and Vancouver Housing Authority have been designated Moving to Work (MTW) agencies, which provides them with additional flexibility in program design and budgeting.

Home Forward and Housing Authority of Washington County have the most one-on-one participant contact with movers. After participants complete a transfer packet and return it to Home Forward, staff schedule a meeting during which a new maximum rent estimate and other materials are provided. This meeting usually lasts 30 to 60 minutes, depending on the number of other issues that need to be addressed, and a packet of information to assist participants with moving is provided at that time. Follow-up communication typically occurs by phone or e-mail. In Washington County, participants bring in a copy of the signed 30-day notice that they have given their landlord and meet with their case worker, who prepares paperwork. Washington County does not have a formal package of materials that are provided at this time, but instead works with participants on an individual basis.

The Housing Authority of Clackamas County conducts a two-hour class for movers who have given their landlord a 30-day notice. The class occurs two to three times per month, depending on demand. Class size can range from two to 20 participants. Participants receive an extensive package of information, including information to help them estimate the approximate maximum monthly rent. Participants are required to submit new income verification information after the 
meeting, and additional paperwork is exchanged via mail or through drop-off/pick-up at the office.

At Vancouver Housing Authority, most of the contact happens over the phone, via mail or via the Internet. Face-to-face contact is not required. The participant initiates contact and searches for housing. No new income verification is required. The rent estimate letter is mailed with the landlord notice form. Once the paperwork is returned from the new landlord and the unit is inspected, a voucher can be issued within a few days.

Thus, from these interviews we learned about the importance of having a toolbox that can be deployed in several different ways: through materials provided in one-on-one meetings, during group meetings, and via the Internet or mail. While comprehensive information was not available on the share of participants with access to the Internet, staff did observe that many participants now go online via their own cell phones or those of younger family members or friends. This was reinforced by a survey conducted by the Housing Authority of Clackamas County in 2012 that found that 45\% of the 392 public housing or HCV participants who responded had “a computer and/or regular access to the Internet” (Clackamas County, 2012).

We also learned that participants are on their own in terms of their housing search. Housing authorities do not have staff time to assist individuals with the process of looking for housing, making contacts with landlords, completing applications or making the final choice. Participants are provided with resources and navigate the process themselves. Housing authority staff provide information about the approximate value of their voucher, the approval process and potential available units. We did learn that a number of the more vulnerable participants may also be served by "partner agencies," including social service providers who handle participants' case management services. Some of these case managers may have more time to spend with participants and could potentially help them get through the housing selection process. Thus, these partner agencies represent an important potential user of the toolbox.

\subsubsection{Relevant Housing Authority Policies}

While many aspects of the HCV program are tightly prescribed by regulations or guidance from the U.S. Department of Housing and Urban Development (HUD), in other instances local housing authorities have some latitude in how they implement the program. As mentioned above, Home Forward and the Vancouver Housing Authority have additional latitude because they have been designated as Moving to Work (MTW) agencies by HUD. Below is a brief list of notable differences among the four agencies at the inception of this study in 2013 and potential implications for the program.

- $\quad$ Payment Standards: As mentioned previously, Home Forward had three different payment standards for studio, one-bedroom and two-bedroom units in high-rent areas and Clackamas County had two. The purpose of having multiple payment standards is to enable voucher holders to afford to live in designated higher-cost areas that have lower poverty rates and/or higher concentrations of community assets ${ }^{9}$.

\footnotetext{
${ }^{9}$ As of December 2015, Home Forward had nine payment standard areas based on zip codes.
} 
- Maximum Share of Income that Participant Can Pay for Rent and Utilities: Unlike the other three agencies, which cap the participant's share of housing costs at $40 \%$ of gross income, Home Forward allows participants to pay as much as $70 \%$ of income on housing costs.

- Overlapping Payments to Landlords: Only one agency, Vancouver Housing Authority, will begin assistance in a new unit before the previous unit's lease has expired. This is very advantageous to the renter, who must otherwise time the beginning of the rental period of the new home to begin precisely when the other one ends or face the possibility of making up the difference from personal savings or a loan. Home Forward issues vouchers before participants leave the previous unit, but does not provide subsidy for the new unit until the day after a unit passes inspection, the day the lease starts, or the day after the move-out day, whichever is latest.

- Lease-up Time Period: The standard lease-up period is 60 days, with extensions provided primarily as a reasonable accommodation. Both the Housing Authority of Washington County and the Housing Authority of Clackamas County followed this standard at the beginning of the study period. Home Forward approved extensions up to 120 days at the beginning of the study period, and provided additional extensions only as a reasonable accommodation for up to 180 days. In April 2014, Home Forward began issuing HCVs with an initial lease-up period of 120 days due to the tight housing market. Home Forward participants face the tightest rental market, and may have a very difficult time finding a place to live. At the beginning of the study period, Vancouver Housing Authority automatically extended the lease-up period to 90 days, and provided 120 to 180 days as a reasonable accommodation.

- Imputed Income: In July 2013, Vancouver Housing Authority began implementing a new imputed income policy as a way to provide a further financial incentive to find work for those participants who were able to do so. The assistance amount is based on an imputed income of $\$ 9,000$ annually per workable household member or the household's actual income, whichever is higher. This minimum imputed income approximates the amount these participants could make working 20 hours per week at minimum wage, and increases the share of housing costs that some participants are required to pay.

\subsubsection{Conclusions about Policies and Practices}

These in-depth interviews were very useful in fine-tuning and, in some cases, identifying potential changes to the proposed toolbox development and evaluation design. Below is a summary of the principal ways that this information affected the project:

- The principal group of housing authority participants to be studied was HCV holders who move from one home to another. Later during the study period, when sequestration ended and some housing authorities began to invite people off their waiting list to participate in the program, a smaller group of new participants, principally from Home Forward, was added to ensure that there were enough study participants.

- To fit seamlessly into existing programs, the toolkit must be adaptable to different institutional contexts.

- The landscape and effective elements of location-efficient, resource-rich housing is different from one county to the next. A home that is location-efficient for one person may not be location- efficient for another, based on the places that household members 
travel to on a regular basis and the modes of transportation that are available. Tools that enable participants to identify housing locations uniquely appropriate to each household should be included in the toolkit.

- The toolkit should provide two kinds of content: messages that support behavioral change and information that aids in decision making. Thus, the toolkit should include both messaging pieces delivered in several kinds of media and technical tools that generate new, individualized information about personally efficient housing locations.

- The questionnaires should capture information about changes in location efficiency and affordability as experienced by individual households.

- The institutional context; the relative tightness of the county housing market (which influences the degree of choice voucher holders have); whether a participant is moving voluntarily or involuntarily; and how firm of a decision the participant has made about future housing are factors that impact the toolkit's effectiveness.

- This research did not occur in a controlled experimental environment. Instead, it occurs in a dynamic one. Changes are likely to happen in housing authority policies and procedures, state law, federal appropriations and the housing market, which will affect the outcomes. Indeed, we subsequently found that such changes did happen. For example, in July 2014 a new Oregon state law went into effect which made it illegal for landlords to refuse applications of HCV participants solely because a source of their income was a HCV. Washington did not enact a similar law. The housing market continued to tighten throughout the study area, and some of the housing authorities responded with increased lease-up times, new payment standard schemes and other program changes to help increase the likelihood that their participants would be able to secure housing. Congress approved a budget, and some housing authorities (most notably Home Forward) were able to offer vouchers to households on their waiting list ("wait list pulls"). We discuss potential implications of these changes in the Conclusions section of this report.

- When undertaking research and evaluation of an intervention, choices often need to be made about whether to tightly control the variables affecting the outcome of the evaluation (a more precise evaluation and firm conclusion), or whether to instead allow variation and "fit-to-circumstances" (a more robust intervention). If the evaluation is of the efficacy of a new drug or medical procedure, the potential negative consequences of reaching an erroneous conclusion due to the lack of tight controls are potentially lifethreatening; thus, researchers follow tight protocols. Following converse logic, an argument can be made in favor of less rigid protocols (more variation among housing authorities) and a more flexible, adaptable intervention on this project because the negative consequences of exposing participants to tools that may or may not be helpful to them are minor. Thus, the research team on this project developed a toolbox of flexible, adaptable tools that could be deployed in a number of different ways.

The final, overall insight gained from these interviews is that the process of finding housing and navigating the voucher process is a complicated one. Housing authorities are unable to provide extensive staff time to help individuals; they are on their own when it comes to finding housing. However, participants are provided with a lot of information intended to help them. It is possible that the amount of information and paperwork could be nearly overwhelming. Furthermore, the 
down side of not finding housing within the allotted time frame could be severe; a participant could lose access to the voucher, which may result in homelessness.

This is the context in which the location-efficient housing toolbox was introduced. This context is explored further in the following section, which examines the experiences of HCV participants in finding housing in the region.

\subsection{EXPERIENCES OF HCV PARTICIPANT MOVERS IN THE REGION}

\subsubsection{Focus Group Design, Methods and Analytical Approach}

To better understand the experience of HCV participants looking for housing in the Portland metro area, in summer 2013 we conducted six focus groups involving 17 HCV participants who had moved within the last year. Our focus group research questions were as follows:

- Do some participants prioritize living in location-efficient and/or location-affordable housing?

- What kinds of barriers do they experience in searching for housing?

- What do these barriers tell us about constraints accessing location-efficient or locationaffordable housing in this context?

- What do participants think about the usefulness of two existing online tools: the Transportation Cost Calculator (TCC), developed by HUD and U.S. DOT, and Walk Score Apartment Finder (WSAF), provided by a private for-profit business?

Participants were recruited by housing authority staff, as they had the greatest rapport with potential participants. The instructions and recruitment materials provided to the housing authorities can be found in Appendix B-3. In selecting whom to invite from among those who had moved within the last 12 months, we asked housing authority staff to "include people from a variety of backgrounds so that we can get the broadest possible understanding of the experiences of voucher holders in your community.” Each housing authority invited a dozen or more participants for each focus group they sponsored. All focus groups were confidential; housing authority staff did not know who ultimately attended, and they were only provided with summary results. As an incentive to encourage participation, participants were told that a drawing for a \$25 gift certificate to a popular local grocery/variety store would be conducted among participants at each focus group.

The sample of 17 individuals from 16 households and four housing authorities included participants with different racial/cultural backgrounds, life stages, family compositions and abilities/disabilities. All had incomes at or below 50\% of area median income, adjusted for household size, as determined by HUD. Some had moved voluntarily, others had moved involuntarily (unit sold or foreclosed), and others had experienced a combination of push and pull factors. The results of these focus groups should be regarded as exploratory and tentative, as we were not able to recruit a sufficient number of participants to conclude that we had reached saturation on any of the key topics. Nevertheless, they were extremely useful in helping to ground the tools in the actual needs and experiences of program participants. 
The focus groups were facilitated by study staff and followed a semi-structured design. Participants were prompted with questions to tell their stories-what caused their move; how they looked for places; the obstacles, assistance and surprises they encountered; and why they ended up with the home that they did. The focus group protocol and consent form can be found in Appendix B-4 and B-5, respectively.

Focus groups were audio recorded, transcribed and thematically coded. The primary topics related to the prompts: cause/purpose of move, search process, barriers, assists, reasons for final choice and satisfaction with new home. We then used an inductive method to identify clusters of related ideas within each topic. Finally, the findings from each focus group were compared and contrasted. We found that, in general, similar themes emerged among all the groups.

\subsubsection{Analysis and Findings from Focus Groups}

This analysis addresses findings related to the first three focus group research questions. Findings regarding the remaining question, which is related to the relevance of specific tools, is addressed in Chapter 3 of this report.

Participants moved due to a variety of reasons, some voluntary and some involuntary. Some were looking for a "better" place, which had different meanings for different people, including more peaceful, more welcoming to families with young children, safer, in better condition, or more affordable. Others moved due to non-renewal of lease, foreclosure of the home, or redevelopment plans by the landlord. Although voucher holders sometimes are forced to move because of an actual or impeding eviction, none of the focus group participants were required to move for this reason. It took voucher holders anywhere from two weeks to seven months to find a new home.

While one might expect those moving due to push factors would experience the most anxiety about finding a place to live, in fact, all participants indicated that they felt that they were under a lot of pressure, in part because participants were required to give notice to their current landlord before a new voucher could be issued. If they didn't find a place, they faced the possibility of doubling up, living in a hotel or being without a home. One single, working mom and her six children said that they stayed in Motel 6 for a week and a half before being able to move into their new place. An older woman described her experience this way:

For the first time, I got anxiety. I didn't know what anxiety was. I had never had it. My heart was pounding. I called my daughter. I had to go stay overnight with her. I was crying because it was scary. You have to be out of a place and you don't have a place to move to. You're going, "What am I going to do?"

Thus, our tentative focus groups findings are consistent with Skobba and Goetz's conclusion that the search process often ends up colored by anxiety and being improvisational. Furthermore, we found evidence suggesting that residents under pressure tended to rely on the skills and resources that they are most comfortable using to find housing. For example, one person who didn't want to use his son's Internet access (i.e., a less familiar approach) said he found a phone book and 
methodically called over 200 rental companies, asking if they accepted Section 8 vouchers. Others used lists provided by the housing authorities. Those who had access to the Internet and felt comfortable with using it found that Craigslist, GoSection8 and Zillow were helpful. Others drove around and looked for rental housing in places where they wanted to live. Many networked with friends and associates. Some of these search methods prompted participants to focus on geographic areas (e.g., driving around, newspaper listings, some online listings), while others did not (e.g., calling rental agencies in alphabetical order). Thus, in contrast to Skobba and Goetz, we find evidence suggesting that the improvisational nature of the search process does not necessarily rule out geography being a factor in how residents look for housing.

Some participants were primarily looking for housing based on the unit's characteristics (such as the presence of a washer and dryer or its accessibility features), while a number of others focused their search on a particular geographic area. Still others felt so pressed by the urgency of finding a place that they felt that they could not be choosey, and they looked at anything available to renters who use housing vouchers as a form of payment that was within their price range and unit size.

There were several different factors driving a location-based search. Some looked in specific areas that they found to be safe, familiar, or close to people who were part of their personal network. Some participants initially excluded areas that had a reputation for being unsafe, represented places where participants thought that they would feel unwelcome, or otherwise made them uncomfortable. Thus, we deduce that being concerned about place is not inconsistent with Clampet-Lundquist's (2003) finding that the driving force behind finding a new place is the maintenance of personal safety networks. We discovered that personal safety could be related to particular people or institutions situated in specific geographies or, conversely, avoidance of other areas that felt unsafe.

Two participants looked for locations specifically to reduce travel time, including the woman quoted below. She said that her move reduced her travel time to work by bus from 45 minutes to 25 minutes:

[In my search process,]I was thinking about the commute to work. Then, like I said, there is a local church, I am $7^{\text {th }}$ Day Adventist, so the local church is walking distance. I grew up at the church, so that made it convenient for me. As far as the stores, a trip to the store is one bus ride to Safeway in St. Johns...As far as school, it is convenient for my son... The school bus picks them up three blocks from home...I knew it would be easier [in the new home than in the former home] if I had to go to my doctor's office. Everything was closer in.

This example offers insights into a concept one might call "personally efficient housing locations.” These are locations near specific destinations that an individual visits regularly. A personally efficient housing location that reduces travel time for Person A might not do the same for Person B, given the different constellation of destinations frequented by each individual. Some destinations may be interchangeable (e.g., one reasonably priced grocery store might work as well as another), but others may be less so (e.g., one's doctor's office or one's mother's home). This concept of personally efficient housing locations contrasts with the academic 
approach to location efficiency, which is associated with characteristics of the built environment and not dependent upon individuals’ or households’ actual travel patterns.

But what about wanting to live in places where the built environment supported location efficiency in general as well as personally efficient housing locations? Consider the experience of a focus group participant who moved from a place in a suburban area dominated by residential subdivisions and commercial strips to a place in the downtown area of that same suburban community. Here's how she described the benefits of that suburban to suburban move:

I really like where I moved. It's downtown, so I am kind of out in the community a little bit more. It was kind of a happy hole where I was [before I moved]. Now I am getting out, being a little more social, and enjoying the place. I grew up in [downtown], so I am enjoying [being back downtown].

Thus, although housing in location-efficient neighborhoods is not likely to be at the top of the list of concerns for all participants when they move, we did find evidence that some experienced benefits from living in such areas. Others actively searched for personally efficient housing locations near places they frequented on a regular basis, suggesting a different way of thinking about location efficiency and affordability as concepts determined by personal networks located in space.

Survey group participants reported many different kinds of barriers that limited their choice of housing locations. The most frequently mentioned barriers were primarily market related: the lack of landlords' willingness to accept HCVs as a form of rental payment (not required by state law in Oregon at the time of the focus groups but later enacted into law effective July 1, 2014), and the difficulty of finding housing that they could afford, even with a voucher. Additional market-related barriers include the lack of accessible units, the lack of affordable units that were safe, and the lack of affordable units that were livable and in good enough condition to pass the required housing inspection. The cost of housing in especially desirable areas affected participants' access to place.

Quite a few participants cited the cost of applications and credit checks to be a problem, as well as a lack of resources to cover moving expenses and the cost of deposits for the new home. These obstacles fall at the intersection of individual, public policy (lack of supplemental resources), and market (discretionary landlord practices) barriers.

Barriers that stemmed primarily from public policy and program issues included the lack of time to find housing; the need for participants to give notice in their current location before they could obtain a new voucher or other statement assuring prospective landlords of their participation in the program; and confusion about program processes. While not specifically mentioned, the lack of assistance with finding housing was another likely policy/program implementation barrier.

Individual barriers related to participants' skills with conducting a housing search have been discussed above. Other individual barriers that surfaced were related to the applicant's rental history, lack of savings and lack of income. Sometimes they simply got discouraged. Individual barriers might affect a renter's ability to access location-efficient neighborhoods. 
In conclusion, the focus groups yielded the following insights that helped inform the toolbox's development:

- The anxiety-driven search process may have been improvisational and chaotic, but a combination of factors resulted in some degree of prioritization by place for at least some participants. So, place does matter, at least in some instances. Thus, it makes sense to provide HCV participants with tools that help them search by location.

- How place matters during the search process, and its relevance to location efficiency and affordability, is less clear. While some voucher holders found that they benefitted from moving to location-efficient neighborhoods, what seemed even more relevant to the actual search process were places nested in an individualized network of frequent destinations. This suggests that tools that help participants identify personally efficient housing locations might be especially useful.

- A potentially important obstacle that inhibits the ability of voucher holders to live in location-efficient and affordable neighborhoods appears be the marketrelated barrier of the cost of housing in those areas. If they cannot afford the rent, then other kinds of assistance or policies will not succeed in helping HCV participants access those areas. Unfortunately, our toolkit does not assist with addressing this substantial barrier. 


\subsection{TOOLKIT DEVELOPMENT}

\subsubsection{Development of the Toolkit Framework}

The toolkit framework was developed in collaboration with representatives from all four housing authorities. Since the scope of our study is broad in terms of geography, economic conditions and policies, we involved as many different people and viewpoints as our time allowed.

The principal processes used in the development of the toolkit were as follows:

- Literature review of housing mobility assistance programs, transportation needs and costs of low-income households, and location-efficient housing for low-income households.

- Onsite interviews with staff from four housing authorities to learn how programs are administered.

- Focus groups with voucher holders to learn how they find housing currently and the challenges they experience during this process.

- Best practices research on successful transportation messaging campaigns.

- A search for other localized tools that we could use as models, and other national tools that we could adopt for use in Portland.

\subsubsection{Focus Group Testing}

Two online components of the toolkit were introduced and tested during the six focus group sessions with HCV participants held during fall 2013. We wanted to expose two locationefficiency and affordability online applications to our target population in an open environment. The two online tools presented were My Transportation Cost Calculator website and Walk Score Apartment Finder website. Each are described below.

\subsubsection{Potential Online Tools}

The Transportation Cost Calculator (TCC) is an application developed in collaboration with the U.S. Department of Housing and Urban Development and the U.S. Department of Transportation. The main purpose of the TCC is to allow users to calculate their unique monthly transportation and housing costs based upon a household's economic profile, vehicle miles travelled, and vehicle profile (MPG, monthly VMT, gas prices). After a household inputs their unique parameters, estimates for three monthly costs are displayed: housing, transportation and total housing plus transportation. Users can compare the costs associated with multiple home addresses. Additionally, households are also shown their costs compared to the Location Affordability Index, which is a modeled estimate of how much an average household with similar attributes would be spending in that location.

Walk Score Apartment Finder (WSAF) is an online application that is provided by a private forprofit organization. Unlike the TCC, which is travel-cost oriented, WSAF provides information 
on travel time. WSAF allows users to enter specific addresses or places, and their intended mode of travel and ideal length of travel. After these parameters are inputted, a map is displayed with a highlighted area of all the places they can reach by their specified mode and travel duration, what we refer to as a "travel zone." The visual presentation of the travel shed allows the user to easily and quickly see the areas and destinations that are accessible to them. Additionally, users are able to generate travel sheds for multiple places, providing the user with potentially overlapping travel sheds. From the visualization of the travel zone, it becomes quite clear which areas are the most efficient to reside in. It should be mentioned that while the WSAF is intended to facilitate finding an apartment, we found its greatest utility coming from the visual display of the travel zone, as the apartments provided did not represent the entire supply of available rental units.

\subsubsection{Online Tool Feedback}

In general, feedback from our presentation of the online tools was positive and encouraging. Participants quickly understood the utility of the online tools and expressed that they could potentially benefit their housing search experience. That being said, it was clear that there were limitations with using online tools that could not be easily overcome.

For our presentation of the TCC we asked for address and destination suggestions from our participants to best replicate their actual situation. It was surprising for participants to see an estimate of their travel costs, as they typically are paid incrementally over time, and not like rent, which is paid in a lump sum.

We received positive feedback from some participants regarding the TCC, as indicated by these comments:

- "Being that the cost of gas is so expensive, I think I would try to stay centrally located, where I go to my church, my family stays in the same area, and that kind of thing."

- "(You can) see how much extra it would cost if you move further, or if you lived further out from your job or closer in. You (can) save quite a bit of money.”

However, participants voiced plenty of concerns about the usability of the TCC. Some of these points addressed the amount of effort needed to calibrate the TCC. Participants are required to enter a substantial amount of data in order for the TCC to produce customized results. Lastly, it was noted by participants that the TCC was geared toward automobile users and did not greatly benefit those reliant upon public transit.

For our presentation of the WSAF, we received the following kinds of comments:

- "It helps narrow it down. It's a great idea. I wish I knew about this... I would have used it."

- "This is interesting because you calculate your time where you want to go and be home before dark... This is great."

- "I think it is awesome. It lets you calculate (distance to) parks and stuff where you need to be basically."

Overall, participants appeared to be more impressed with the visual display provided by the WSAF than with the cost information provided by the TCC. 
Here is a small collection of the positive feedback we received from the online tools as a whole:

- "...if I did not have a vehicle and I wanted to walk to the store to get my groceries or maybe as I get older, I can see why I would use it.”

- " "...it gives you options of how far you can go and how long it is to get you there."

- " "It could give you a familiar feel of the area you're in."

- “To me, I don’t really care how long it takes me to get to work as long as my children are living in a good area and good schools.”

Lastly, it became apparent during our presentation of the online tools that they may ultimately not be accessible to a substantial portion of our target population. For example, the following comments were made during our sessions:

- "You have to be computer savvy."

- "Our computer is not set up. We do not have Internet at our house set up yet."

- "I believe human contact is the only way to get things done."

- “When you're looking for a place, your mind doesn’t think to go on the map and look through all that. You're just trying to look for a place. I would consider something like that (...) when I have time to look and I'm not stress (emergency) moving.”

Having online components in our toolkit exposed us to the potential of not reaching portions of our population. Due to our limited sample, we cannot speculate whether these comments represent a large portion of our target population of voucher holders. However, it is possible that many HCV participants may access online tools through smartphones or with assistance from friends or family, though we cannot determine exactly how many participants lack access to the Internet or are unable or unwilling to use these types of applications.

\subsubsection{Housing Authority Feedback}

After completing our focus group sessions with HCV participants, we presented our emerging toolkit to staff from all four housing authorities at meetings held at Home Forward and VHA. The presentations were held to inform staff about the Location- Efficient Housing Toolkit Project, as well as get their feedback on potential elements of the toolkit. These presentations served as a forum in which staff members could voice their concerns, questions and comments regarding the project and toolkit. Additionally, involving housing authority staff at this point in the project provided an opportunity to gain invaluable firsthand knowledge about the needs and desires of program participants, as well as sharing appropriate ways to communicate or message the toolkit to this population.

\subsubsection{Presentation Details}

The presentations were open to staff members from all four housing authorities and lasted between 90 minutes and two hours. Staff from Home Forward, Washington County and Clackamas County attended Presentation 1, and VHA staff attended Presentation 2. An introduction to the Portland State University (PSU) research team was provided to the staff members before going into the details of the project. The project's purpose, design and implementation (toolbox) were outlined to the groups. During the VHA presentation, a 
discussion on messaging took place before the toolkit pieces were unveiled. After this, the two online tools (WSAF \& TCC) were introduced. A brief walk-through of each tool was demonstrated, followed by a group discussion regarding each tool. Lastly, there was an opportunity to bring up any closing thoughts on the toolkit.

\subsubsection{Feedback from Presentation 1}

The major themes of the feedback are as follows:

- Participants need to find a place to live quickly.

- WSAF needs a Section 8 filter.

- Tremendous concern regarding wasting participants’ time.

- Toolkit may only be appropriate for a small percentage of participants.

- Mobility counselors may not have sufficient time to administer toolkit.

Participants need to find a place to live quickly.

Participants face many obstacles during their search process, the most pertinent being the ability to find landlords who accept HCVs. Case managers felt it would be counterproductive to offer them anything that was not tied into helping them find available housing that accepts HCVs. Lastly, there were a couple of voices who mentioned that transportation is not important at all to their participants.

WSAF needs a Section 8 filter.

A majority of housing authority staff members agreed that the WSAF was a great application, but questioned the utility of its current functionality. Without the ability for participants to filter out housing that does not accept Section 8, participants would become frustrated with the application and stop using it. There was consensus that WSAF may become just another "dead end” for participants. There was widespread agreement that if WSAF had a Section 8 filter, it would be a "game changer."

Tremendous concern regarding wasting participants' time.

Case managers voiced concern about sending participants on "wild goose chases," which they believed WSAF might become to them. There was fear that WSAF may give participants "false hope” and not help in finding a new home. TCC would also be a waste of time if participants did not own or drive a vehicle.

Toolkit may only be appropriate for a small percentage of participants. Case managers questioned the usefulness of the toolkit if it could only provide assistance for a small fraction of participants. Staff may be resistant to introducing these tools if they do not work for the majority of their participants.

Mobility counselors may not have sufficient time to administer toolkit. Especially with TCC, the amount of time necessary to administer the tools in the toolkit would be troubling. It was suggested that the toolkit take the form of a handout or "takeaway." These printouts, describing the toolkit and how to use it, could then be made available near public computers available at the housing authorities. TCC would be too cumbersome to use during 
face-to-face meetings. TCC would be useful if participants provided necessary information prior to the meeting.

\subsubsection{Feedback from Presentation 2}

The major themes of the feedback are as follows:

- Messaging

o Beneficial to provide an online video accessible to participants.

o Provide static customizable maps for transit access.

o Messages should provide comparable information based upon location choices.

o "Savings" should be presented in various units of measurement.

o "We know you have challenges; don't forget you have choices"

- MTCC is too complicated and instead should provide the "bottom line."

- WSAF would be a useful addition to the search process.

\section{Messaging}

Providing tools participants can access at their leisure was mentioned to be essential. Online videos, customizable maps and mail-able items were suggested as ways to reach participants outside of the housing authority offices. Additionally, messages that highlight the question, "What's in it for me?" are thought to be important. Relatable accounts, such as "Tracy moved to a walkable neighborhood and now saves \$200 a month in transportation costs!” also received positive reactions. Finally, given that many of our tools require user inputs, it was recommended that a section of our messaging include "Things to think about first." This would serve as the time in which the participants could gather the items or information needed to conduct a location-efficient housing search.

TCC is too complicated and instead should provide the "bottom line."

There was concern that participants may get "lost in the details" when navigating the TCC tool. Instead, it was recommended that a more generable output was presented using information from TCC. We should get to the "bottom line;" that is, tell them that they will save money by living in a location-efficient home, without having them be burdened by a large amount of inputs.

WSAF would be a useful addition to the search process.

The response was that this would be a useful tool when participants were planning a move. It was thought that this should be the first tool that is presented to the participant. Also, it was expressed that the WSAF would allow people to gauge whether their daily needs could be met at alternate locations, when compared to where they currently live. The only caveat mentioned regarding the WSAF was that it does not presently have data provided by C-TRAN.

\subsubsection{Conclusions Regarding Housing Authority Feedback}

The feedback received from the two presentations brought forth a broad range of perspectives regarding the project and toolkit. Overall, the various attitudes and opinions concerning the potential toolkit items may ultimately affect project outcomes. 


\section{Two main takeaways}

- Constructive ideas about messaging were heard. Tools that participants can access on their own; fictional representative participant personas; and a customizable worksheet or maps were deemed very important.

- Some housing authority staff may be resistant to introducing the toolkit. Consequently, this may affect the outcome of the project.

\subsubsection{Messaging Pieces}

Two messaging products were developed for the toolkit: 1) a pamphlet that contained key messaging components on including transportation costs when considering housing choices; and 2) a six-minute video that provided a narrative and visual presentation of the key messaging themes. Both products were conceptualized and produced by the research team and housing authority Steering Committee through an iterative process. Housing authority staff helped to ensure that these products presented ideas clearly and in simple language that was meaningful to program participants.

These products focused on the following messages:

- When you choose a place to live, you're choosing more than a safe, affordable space for you and your family. You're also choosing how you will get around, and how much time and money you will spend getting around.

- In our area, transportation costs about $30 \%$ of what families with housing assistance earn each month. For many, that's about as much as your housing costs.

- Unlike housing costs, transportation costs can sneak up on you. Most people know how much they pay for rent because it's paid all at once. But most people don't realize how much they spend on transportation, as the costs are paid gradually. Gas, bus passes, car repairs and insurance all add up.

- What can you do about transportation costs?

o Think of the places where you go often. Then identify an area where you could get to your regular destinations in a reasonable amount of time and at a reasonable cost. This is your travel zone. Start your search for housing there.

o Compare not just places, but also commutes.

o Think about other ways to travel. Consider whether transit, biking or walking, instead of driving, is reasonable.

- You may have challenges with finding a place to live, but a housing voucher expands your options. Consider your transportation options and costs before you make a move.

\subsubsection{Elements of the Toolkit}

The final toolkit involves elements from various sources of information relevant to our topic. The information gathered from the housing authorities; extensive research literature; consultation seminars with housing authority staff; project Steering Committee meetings; focus group sessions with voucher holders; and email correspondence was collated and analyzed. Global themes soon emerged to form the framework of the toolkit. The resultant toolkit included: 
- A messaging pamphlet. Website addresses were provided for Walk Score Apartment Finder, Padmapper and Google Maps.

- A messaging video that also demonstrated how Walk Score Apartment Finder could be used.

- A Walk Score written guide that helps movers navigate and utilize the Walk Score Apartment Finder online tool.

- A "house finding" checklist that integrates transportation options and costs into the topics movers should consider when looking for a new home.

- A transportation and housing cost comparison worksheet.

- Sample introductory website text that housing authorities could customize and use for introducing the toolkit.

Copies of these tools and a link to the video are provided in Appendices C-1 through C-6.

\subsection{INTEGRATION OF TOOLS}

In March-May 2014, the final toolkit was introduced to housing authority staff with direct contact with participants (e.g., case managers and front office staff) through meetings at each of the four housing authorities. The housing authorities were given flexibility to integrate the toolkit in ways that were consistent with their standing procedures. The following is a brief description of how each housing authority provided the toolkit to their participants.

- Clackamas County: Toolkit provided during bi-weekly group meeting for movers. Video was presented during this meeting. Toolkit handouts were integrated into existing packet given to prospective movers.

- Home Forward: Staff provided toolkit during standardized one-on-one meetings with current participants who intended to move.

- Washington County: Prospective movers met with housing authority staff on an individual basis, at which time the toolkit was presented.

- Vancouver: Toolkit was mailed to prospective movers once their move notice was received.

Additionally, each housing authority provided its participants with directions on how to access the toolkit's online components. 


\subsection{EVALUATION}

\subsection{EVALUATION DESIGN}

This study uses a pre-test, post-test with control group research design to evaluate the effectiveness of the toolkit (also referred to as the "intervention"). This evaluation design was specified in the Request for Proposals issued by the housing authorities.

This design is most effective in research settings with a relatively high degree of control over the research environment, or where researchers can statistically control for external influences or internal variations. As has been indicated previously, this research took place in a context where major external factors, such as changes in the housing market, policies and procedures, as well as internal factors, such as case manager interest and potential participants' willingness to participate, may have had a major impact on both the composition of the sample groups and the evaluation outcomes. In most cases, we have not been able to control for these factors through changes in the research design or through statistical controls. Instead, we have noted them and described potential effects on the evaluation results.

The assessment instrument consists of two written surveys (a two-wave survey design) completed by the participants before they moved and after they moved, called Survey 1 and Survey 2, respectively. The Control Group consisted of HCV participants who were not exposed to the mobility toolkit; the toolkit was still under development when they elected to participate in the study. The Intervention Group completed Survey 1 before being exposed to the mobility toolkit. Both groups completed Survey 2 after moving. While Survey 2 was the same for both groups, modifications in Survey 1 were made for the Intervention Group to ensure that they had not seen the toolkit before completing Survey 1. Copies of the surveys can be found in Appendices D-1 through D-3.

The surveys were designed to help determine whether participants' knowledge and behavior with respect to transportation costs and factors affecting housing choices changed as a result of exposure to the toolkit. Our intention at the outset was to compare the changes in the answers for the Intervention Group (between Survey 1 and Survey 2) to the corresponding changes for the Control Group in these areas:

Knowledge

- Awareness of transportation costs

- Awareness of benefits of location-efficient housing

Behavior

- Household transportation costs

- Share of routine trips completed by personal vehicle

- Share of routine trips completed by walking, biking and public transit 
The surveys also included questions about the factors that participants considered in looking for a new home.

\subsection{SURVEY DEVELOPMENT}

\subsubsection{Theoretical Background}

The development of the survey was influenced by the Theory of Planned Behavior postulated by Icek Ajzen to predict whether an individual would have the intention of undertaking a specific behavior, such as participating in an exercise program (Ajzen, 1985). It is a widely used psychological theory and has often been used in transportation research (Adkins, 2014). In this model, depicted in Figure 4.1 below, three principal interacting factors affect intention:

- Attitudes/beliefs: One's evaluation (favorable to unfavorable) of the behavior and its outcome.

- Norms: Whether people important to the individual perform the behavior and whether they think the individual should perform it.

- Perceived behavioral control: Perceived presence/absence of factors that may hinder or help ensure performance of behavior.

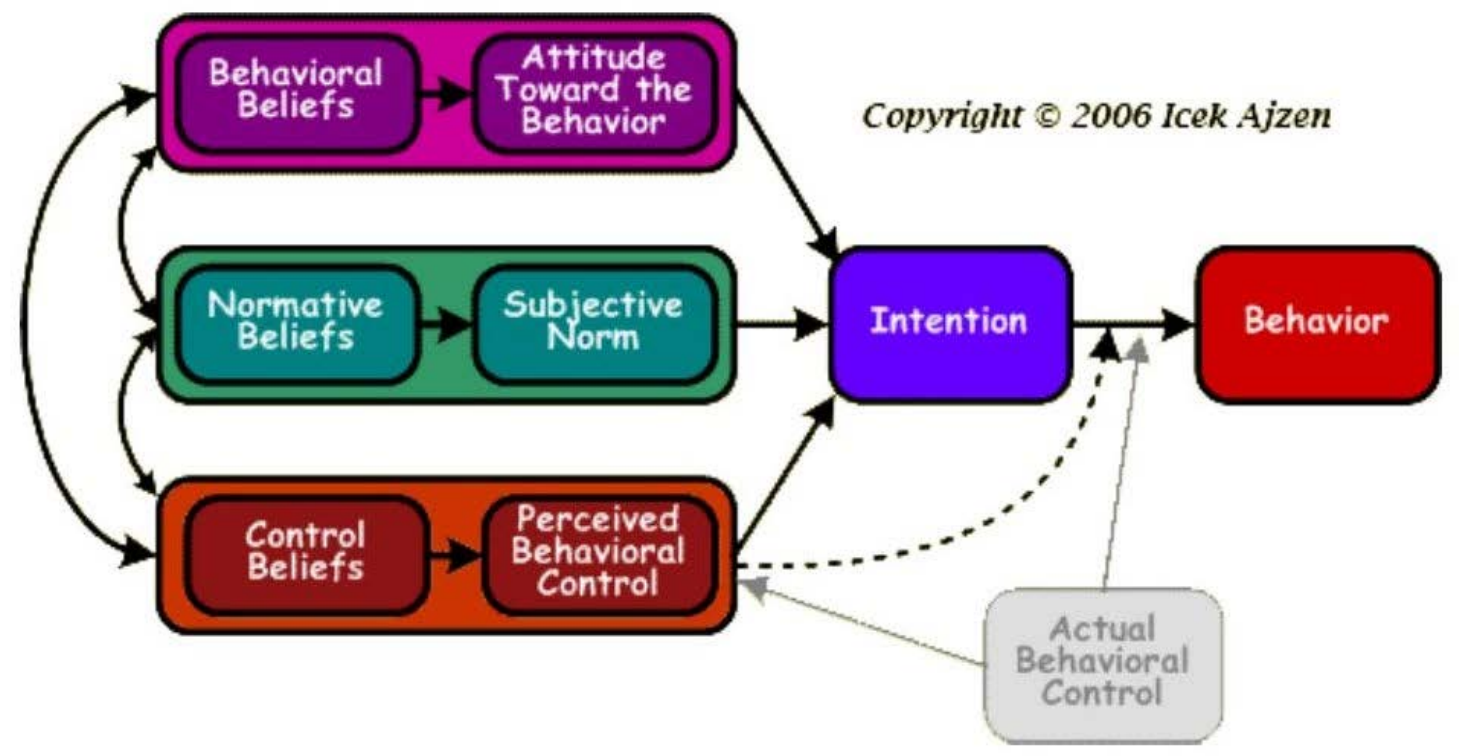

Source: Boston University School of Public Health http://sphweb.bumc.bu.edu/otlt/MPH-Modules/SB/SB721-Models/SB721-Models3.html

Figure 4.1: Theory of Planned Behavior

The logic of the surveys and the content of individual items were influenced by the dissertation research of Arlie Adkins, a research team member. Adkins (2014) developed a two-wave survey that was administered to new movers in six U.S. cities to examine how this group made choices 
about active transportation modes while adapting to a new home and neighborhood. Adkins patterned his survey on research in other fields built around the Theory of Planned Behavior.

Adkins (2014) found that the built environment played a key role in determining whether movers walked more as a transportation mode, and that both social norms and perceived behavioral control had a mediating effect on this outcome. Apropos to this study, Adkins also found that that low-income movers who prioritized moving to a walkable place were about half as likely as higher-income movers to actually be able to realize that intention.

\subsubsection{Question Development and Refinement}

Key survey questions for this study were based on questions developed by Adkins (2014). Housing authority representatives contributed substantially to the survey design, and provided feedback to help improve the language and phrasing so that it would make sense to HCV participants. One limitation in this project was that the survey and tools were only available in English, thus excluding those with limited English proficiency from this study. The written survey and tools also exclude the visually impaired and others not able to independently complete a written survey.

Survey 1 included questions related to the following areas:

- Current behavior: Current transportation modes for frequent destinations and current mode split.

- Norms: Friends who get around by walking, by public transportation, by cycling or without a car.

- Perceived behavioral control: Belief that one could find a home that would support a mode shift to more walking, a decrease in transportation costs or improved access to good public transportation.

- Intention: Intended changes in transportation behavior (mode shift) as a result of a move.

Survey 1 was field tested and further refinements were made before it was administered to study participants.

The team chose to streamline Survey 2 and focus on transportation behaviors in the new home. Survey 2 also asked directly about the usefulness and importance of various resources in the home search, including the tools in the toolkit developed in Phase 1 of this project.

The survey questions analyzed as part of this evaluation are listed below.

\section{Evaluation Questions}

- Intention (Survey 1): When you think about your new home, how much do you intend to walk, drive, use transit and bike for transportation purposes compared to your current home?

- $\quad$ Perceived Behavioral Control (Surveys 1 \& 2)

o It is easy to walk to a bus stop or light rail station from my home. (Agree or Disagree)

o My neighborhood is a good place for walking. (Agree or Disagree) 
- Behavior (Surveys 1 \& 2): Survey $1=$ former home. Survey $2=$ new home

0 There are many places I go within easy walking distance of my home. (Agree or Disagree)

o In the last week, how much of your daily travel was by each of the following? (Walk/Transit/Car/Bicycle)

- Behavior Change (Survey 2): In your new home, how much do you walk, drive, use transit and bike for transportation purposes compared to your former home?

- Anticipated and actual factors influencing choice of new home (Surveys 1 \& 2): How important are each of the following to you in choosing your new home?

o See Appendix D-1, Question 9, for complete list of items.

- Tool familiarity (Survey 2): How familiar are you with each of the following tools?

o List of places for rent from my housing authority

o Online map, like Google Maps or Yahoo Maps

o Transportation Cost Worksheet from my housing authority

o Walk Score Apartment Finder

o Craigslist.org

o GoSection8.com

o Check It Out checklist from my housing authority

o My housing authority's video on housing \& transportation costs

o Transpo-rent.org [an imaginary website included to test accuracy of responses]

o Transportation Toolkit for Movers from my housing authority

- Tool importance (Survey 2): How important were each of the following tools in your search for housing?

o See list above

- Housing and Transportation Cost Change (Survey 2): Now that you've moved, how have your costs for the following things changed?

o Housing costs (rent, utilities, etc.)

o Transportation costs (gas, bus tickets, etc.)

o Housing \& transportation costs combined

- Satisfaction with Choice (Survey 2): All things considered, which home do you prefer to live in?

Surveys 1 and 2 also included descriptive questions to enable insights into the demographic and other characteristics of our population. These are listed below.

Descriptive Questions

- How certain are you of where you want to live when you move?

- Why are you moving?

- Are you Male or Female?

- In what year were you born?

- Do you currently have a valid driver's license?

- Do you have access to a car on most days?

- Do you have access to a bicycle on most days?

- Do you consider yourself either Hispanic or Latino/a?

- What is your race/ethnicity? 
- Are you currently employed in a job outside your home?

- What is your annual household income?

- Do you have a physical limitation that prevents you from walking?

- Can you comfortably ride a bicycle?

- Do you use a wheel chair or scooter regularly?

- Have you received a toolkit from your housing authority to help you consider your daily costs when choosing a new home?

\subsection{SURVEY ADMINISTRATION}

\subsubsection{Survey Distribution}

Appendix A, Project Timeline, provides a visual representation of the schedule for survey distribution. The key components are as follows:

- Control Group Survey 1 was distributed by housing authorities from December 2013 through March 2014. The toolkit was not available during this period.

- Control Group Survey 2 was distributed to the participants who completed Control Group Survey 1 and completed a successful move. The distribution of this survey concluded in March 2015.

- Intervention Group Survey 1 was distributed by housing authorities beginning April 1, 2014. To ensure that participants completed Survey 1 before they saw the toolkit, toolkit access was provided only to participants who completed Intervention Group Survey 1, and then only through a restricted website. Recruitment of Intervention Group participants and distribution of Survey 1 continued through December 2014 for Home Forward. The recruitment period for the Intervention Group for HAWC, HACC and VHA continued through February 2015, to increase the number of participants from these smaller housing authorities. Restricted access to the toolkit ended in March 2015, after survey distribution ended for Control Group Survey 2 and Intervention Group Survey 1. Housing authorities could provide open access to the toolkit via their website beginning April 2015.

- Intervention Group Survey 2 was distributed to participants who completed Intervention Group Survey 1 and who had moved. The distribution of IGS2 concluded July 15, 2015.

Informed consent was obtained by providing participants with a project information sheet (see Appendix E) with a copy of Survey 1. In addition to providing information, it also indicated that a participant provided consent by completing the survey. Participants who returned both surveys were offered a $\$ 10$ gift card to Fred Meyer in recognition of their time and effort.

The method of survey distribution varied with each housing authority. The completed surveys were sent to the PSU research team with only an identifying number. The research team never had access to the personal information of participants. 


\subsubsection{Survey Cleaning and Entry}

We received surveys from 339 participants. Only data for participants who fully completed both Survey 1 and 2 were entered for this stage of the study. Some participants were dropped from our study due to inaccurate group classification. In total, we had 125 fully completed pairs of surveys from our target population. Surveys were manually entered into a statistical software application.

\subsection{SAMPLE CHARACTERISTICS AND SUBSETS}

The following descriptive analysis contains data collected from the Control and Intervention groups. The primary goals in this analysis are to provide a descriptive profile of the sampled populations and to test the effectiveness of the intervention.

Comparing available participant characteristics (Table 4.1) to the characteristics of the general HCV participants in the Portland metropolitan area in 2012 (HUD, 2012) shows that the evaluation participants tend to be younger, on average, than HCV participants in the Portland metro overall, and that the percent of households with children is higher ${ }^{10}$. Additionally, there are fewer people of color in the evaluation than reported in the Portland metro HCV population. These differences suggest that a nonresponse bias may affect the results of the evaluation.

The Control Group had a more representative distribution of participants across the Portland metro area than the Intervention Group. In the Control Group, Home Forward accounted for 55\% of the participants, while in the Intervention Group they accounted for $90 \%$ of the population.

Table 4.1: Sample Descriptive Statistics

\begin{tabular}{l|l|l|l|l}
\hline \multirow{2}{*}{ Participant Characteristics } & \multirow{2}{*}{ Control } & Intervention & \multirow{2}{*}{ All Groups } \\
\cline { 3 - 5 } & & Tools Yes & Tools No & \\
\hline$N^{*}$ & 40 & 39 & 46 & 125 \\
\hline Percent Female & $85 \%$ & $80 \%$ & $70 \%$ & $78 \%$ \\
\hline Percent Aged 62 and Older & $10 \%$ & $13 \%$ & $15 \%$ & $13 \%$ \\
\hline Percent Hispanic or Latino/a & $55 \%$ & $36 \%$ & $50 \%$ & $47 \%$ \\
\hline Percent People of Color & $8 \%$ & $3 \%$ & $7 \%$ & $6 \%$ \\
\hline Percent People with Disabilities & $36 \%$ & $39 \%$ & $24 \%$ & $32 \%$ \\
\hline Percent Employed & $40 \%$ & $33 \%$ & $46 \%$ & $40 \%$ \\
\hline Percent HH Income $<10,000$ & $31 \%$ & $26 \%$ & $11 \%$ & $22 \%$ \\
\hline
\end{tabular}

*N may vary in subsequent tables owing to missing values on some variables

The Intervention Group consisted of two different sub-populations: one indicating that they did not remember receiving a mobility toolkit ${ }^{11}$ (Int No) and one indicating that they did receive a

\footnotetext{
10 The true population for this project is HCV participants who moved during the study period. However, descriptive data are not available for this population and the data concerning all HCV participants presented in Table 2.2 is used for comparison purposes instead.

${ }^{11}$ For this group, two possibilities exist: They did not receive the toolkit, or they did receive the toolkit but did not remember seeing it. While it would be interesting and relevant to know whether the lack of memorability stemmed from the design and presentation of the toolkit (i.e., it "got lost in the paperwork" associated with moves), or whether it simply was not provided, we do not have a way to determine, on a case by case basis, which occurred.
} 
transportation toolkit from their respective housing authority (Int Yes). Identification of these two groups was possible through the following survey question:

"Before you moved, did you receive information or a Transportation Toolkit from your housing authority to help you consider everyday transportation costs in choosing your new home?”

Upon further inspection, we found that the Int No Group provided a better comparison group for analysis purposes than the actual Control Group, based on the following factors:

- Study involvement for Int No Group was contemporaneous with the Int Yes Group, while Control Group data was collected a few months to a year prior. This meant that the Int Yes and Int No Groups experienced similar external conditions, including the same housing market, and they were subject to the same housing policies. In contrast, the Control Group experienced a looser housing market and, in some cases, different lease-up periods and other rules. These differences, especially the tightening housing market, could affect the evaluation outcomes.

- As previously noted, Home Forward serves the city of Portland and east Multnomah County, while the other housing authorities serve the outlying counties (Clackamas, Washington and Clark counties) ${ }^{12}$. The differences in the built environment between Portland and the more rural and suburban cities in the other cities may influence the travel behaviors, travel costs and housing options of the participants in the evaluation. These differences could affect project outcomes.

Thus, the statistical analysis and evaluation that follows is conducted using the Int No Group (instead of the Control Group) as a basis for comparison for the Int Yes Group.

\subsection{RESULTS}

The following section explains what we found in our comparison of transportation preferences, transportation costs and toolkit use between the Int Yes and Int No Groups.

\subsubsection{Analytical Findings}

Overall, our analysis was not able to find many statistically significant differences between the intervention groups with the variables we tested in our models. However, our results did show that participants who remember receiving the toolkit (Int Yes) found it easier to walk to transit after moving compared to participants who do not recall receiving the toolkit (Int No). Additionally, participants who remember receiving the toolkit indicated that their housing costs decreased while the other group indicated that their housing costs increased, as indicated in Table 4.2 below.

Thus, for the purpose of this analysis, we treat the effect on the mover as being the same: the toolkit did not cognitively exist for them, and thus it could not have an effect on their attitudes or behaviors.

${ }^{12}$ Home Forward officially serves all of Multnomah County, including the cities of Portland, Wood Village, Fairview, Troutdale and Gresham. 
Table 4.2: Perceived Behavioral Control, Walking and Transit Access

Thinking about your current home and neighborhood, to what extent do you agree with each statement? 1: Strongly agree; 2: Agree; 3: Disagree; 4: Strongly disagree

\begin{tabular}{|c|c|c|c|c|c|c|}
\hline Variable & $\begin{array}{l}\text { Groups } \\
\text { Compared* }\end{array}$ & Pre-Move & Post-Move & Diff & $\begin{array}{l}\text { Mean } \\
\text { Diff }\end{array}$ & Sig. \\
\hline \multirow{2}{*}{$\begin{array}{l}\text { There are many places I go } \\
\text { within easy walking distance of } \\
\text { my home. }\end{array}$} & Int No & 2.89 & 3.02 & 0.13 & \multirow[b]{2}{*}{0.00} & \multirow[b]{2}{*}{0.85} \\
\hline & Int Yes & 3.05 & 3.18 & 0.13 & & \\
\hline \multirow{2}{*}{$\begin{array}{l}\text { It is easy to walk to a bus stop or } \\
\text { light rail station from my home. }\end{array}$} & Int No & 3.43 & 3.20 & -0.23 & \multirow{2}{*}{-0.44} & \multirow{2}{*}{0.08} \\
\hline & Int Yes & 3.21 & 3.42 & 0.21 & & \\
\hline \multirow{2}{*}{$\begin{array}{l}\text { My neighborhood is a good } \\
\text { place for walking. }\end{array}$} & Int No & 2.67 & 2.91 & 0.24 & \multirow{2}{*}{-0.25} & \multirow{2}{*}{0.39} \\
\hline & Int Yes & 2.67 & 3.16 & 0.49 & & \\
\hline
\end{tabular}

*Int No (N=46); Int Yes (N=39); Bold = $p<.1$

Table 4.3: Changes in Housing and Transportation Costs

Now that you've moved, how have your costs for the following things changed?

1: Decreased; 2: About the same; 3: Increased

\begin{tabular}{|c|c|c|c|c|}
\hline Variable & Intervention* & Mean & Mean Diff & Sig. \\
\hline \multirow{2}{*}{ Housing costs } & Int No & 2.16 & \multirow{2}{*}{-0.32} & \multirow{2}{*}{0.10} \\
\hline & Int Yes & 1.84 & & \\
\hline \multirow{2}{*}{ Transportation costs } & Int No & 2.10 & \multirow{2}{*}{0.02} & \multirow{2}{*}{0.89} \\
\hline & Int Yes & 2.12 & & \\
\hline \multirow{2}{*}{ Housing/Transportation costs combined } & Int No & 2.17 & \multirow{2}{*}{-0.08} & \multirow{2}{*}{0.70} \\
\hline & Int Yes & 2.09 & & \\
\hline
\end{tabular}

*Int No (N=46); Int Yes (N=39); Bold $=p<.1$

To what degree are these differences explained by exposure to the toolkit? Our analysis of familiarity and importance of the toolkit components, presented in Tables 4.4 and 4.5, reveals distinct differences between those who recall receiving the toolkit and those who do not.

Participants who do recall the toolkit indicate that they are, understandably, more familiar with each component of the toolkit than those who do not recall receiving it. Additionally, participants who recall the toolkit found each component of it more important in their search for housing than those who do not recall receiving the toolkit. Both of these findings are positive and demonstrate that, for some participants, the toolkit was successfully administered to the participant by their housing authority.

Furthermore, all toolkit pieces were rated as being moderately important during the housing search for the group that remembered seeing the toolkit. Unfortunately, even for participants who remembered receiving the toolkit, the components do not rank high in familiarity or importance when compared to the more traditional tools available to HCV movers. However, it should be mentioned that no tool provided on the survey, whether it be in the toolkit or a more traditional type, rated higher than a 2.9 in importance on the scale of 1-4. This could be an indication that our survey's list of potential tools failed to include tools that are actually used during the search process for this population. Or, the overall medium strength ratings could be an indication that the search for housing is extremely difficult for this population, and that no single tool available could remedy this situation. 
Table 4.4: Familiarity with Tools

How familiar are you with each of the following tools?

$1=$ Not at all familiar; 2 = Mod familiar; $3=$ Very familiar; $4=$ Extremely familiar

\begin{tabular}{l|l|l|l|l}
\hline \multirow{2}{*}{ Tool } & \multicolumn{2}{|l|}{ Intervention* } & \multirow{2}{*}{ Mean Diff } & \multirow{2}{*}{ Sig. } \\
\cline { 2 - 4 } & Tools No & Tools Yes & & \\
\hline List of place for rent from my housing authority & 2.41 & 2.46 & 0.05 & 0.72 \\
\hline Craigslist.org & 2.36 & 2.39 & 0.04 & 0.83 \\
\hline Online map, like Google Maps or Yahoo Maps & 2.22 & 2.10 & -0.12 & 0.51 \\
\hline GoSection8.com & 1.75 & 1.97 & 0.22 & 0.23 \\
\hline \#Walk Score Apartment Finder & 1.50 & 1.82 & 0.32 & $\mathbf{0 . 0 5}$ \\
\hline \#Check It Out checklist from my housing authority & 1.45 & 1.81 & 0.36 & $\mathbf{0 . 0 3}$ \\
\hline $\begin{array}{l}\text { \#Transportation Cost Worksheet from my housing } \\
\text { authority }\end{array}$ & 1.47 & 1.79 & 0.33 & $\mathbf{0 . 0 4}$ \\
\hline $\begin{array}{l}\text { \#My housing authority's video on housing \& } \\
\text { transportation costs }\end{array}$ & 1.20 & 1.71 & 0.51 & $\mathbf{0 . 0 0}$ \\
\hline $\begin{array}{l}\text { \#Transportation Toolkit for movers from my housing } \\
\text { authority }\end{array}$ & 1.20 & 1.50 & 0.30 & $\mathbf{0 . 0 2}$ \\
\hline
\end{tabular}

\#Part of Toolkit; *Int No (N=46); Int Yes (N=39); Bold $=p<.1$

Table 4.5: Importance of Tools

How important was each tool in your search for your new home?

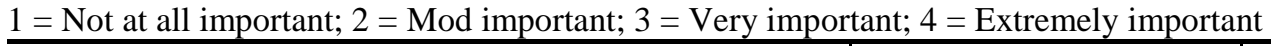

\begin{tabular}{l|l|l|l|l}
\hline \multirow{2}{*}{ Tool } & \multicolumn{2}{|l|}{ Intervention* } & \multirow{2}{*}{ Mean Diff } & \multirow{2}{*}{ Sig. } \\
\cline { 2 - 4 } & Tools No & Tools Yes & & \\
\hline List of place for rent from my housing authority & 2.40 & 2.87 & 0.47 & 0.05 \\
\hline Craigslist.org & 2.49 & 2.86 & 0.37 & 0.18 \\
\hline Meeting with my housing authority representative & 2.44 & 2.79 & 0.35 & 0.20 \\
\hline Suggestions from friends or family & 2.53 & 2.53 & -0.01 & 0.97 \\
\hline GoSection8.com & 2.09 & 2.44 & 0.36 & 0.16 \\
\hline Online map, like Google Maps or Yahoo Maps & 2.20 & 2.38 & 0.18 & 0.46 \\
\hline \#Check It Out checklist from my housing authority & 1.63 & 2.22 & 0.60 & $\mathbf{0 . 0 1}$ \\
\hline $\begin{array}{l}\text { \#Transportation Cost Worksheet from my housing } \\
\text { authority }\end{array}$ & 1.52 & 2.09 & 0.56 & $\mathbf{0 . 0 1}$ \\
\hline \#Walk Score Apartment Finder & 1.65 & 2.00 & 0.35 & $\mathbf{0 . 1 0}$ \\
\hline $\begin{array}{l}\text { \#Transportation Toolkit for movers from my housing } \\
\text { authority }\end{array}$ & 1.45 & 1.97 & 0.52 & $\mathbf{0 . 0 1}$ \\
\hline $\begin{array}{l}\text { \#My housing authority's video on housing \& } \\
\text { transportation costs }\end{array}$ & 1.57 & 1.92 & 0.35 & $\mathbf{0 . 0 7}$ \\
\hline
\end{tabular}

\#Part of Toolkit; *Int No (N=46); Int Yes $(\mathrm{N}=39)$; Bold $=p<.1$

\subsubsection{Additional Findings}

A broader analysis of the dataset led to additional discoveries concerning the population. Most of these findings do not directly test the effect of the toolkit, but instead provide a deeper understanding of the population's preferences and behaviors, as well as guidance on factors that may improve future iterations of the toolkit.

Table 4.6 examines the pre- and post-move importance of a wide range of items during the process of choosing of a new home. Topping the list are those related to safety or characteristics of the unit. In regard to transportation items, it is encouraging to notice that Low Transportation 
Costs, Good Public Transportation, Easy Access to Medical and Social Services, and Sidewalks rate relatively high in level of importance. Conversely, the transportation items related to Freeway Access, Walking Distance to Schools, Places to Eat in Walking Distance, and Access to Bike Routes are all ranked quite low in importance for this population. The changes between pre-move and post-move responses, while statistically significant in several instances, do not appear to reflect major attitudinal shifts.

Table 4.6: Factors Influencing Choice of Home

How important were each of the following to you in choosing your new home?

1 = Not at all important; 2 = Mod important; 3 = Very important; 4 = Extremely important

\begin{tabular}{|c|c|c|c|c|}
\hline \multirow{2}{*}{ Variable } & \multicolumn{2}{|l|}{ All Groups } & \multirow{2}{*}{ Difference } & \multirow{2}{*}{ Sig. } \\
\hline & Pre-Move & Post-Move & & \\
\hline Neighborhood feels safe & 3.7 & 3.5 & -0.15 & 0.06 \\
\hline Property and unit well-maintained & 3.6 & 3.4 & -0.20 & 0.01 \\
\hline Helpful property manager & 3.5 & 3.4 & -0.11 & 0.15 \\
\hline Cheaper rent and utilities & 3.4 & 3.2 & -0.16 & 0.11 \\
\hline *Low transportation costs & 3.1 & 2.9 & -0.18 & 0.04 \\
\hline *Good public transportation & 3.0 & 2.9 & -0.15 & 0.11 \\
\hline *Easy access to medical and social services & 3.0 & 2.9 & -0.18 & 0.05 \\
\hline *Sidewalks throughout the neighborhood & 3.0 & 2.8 & -0.16 & 0.12 \\
\hline A place where I fit in & 3.0 & 2.8 & -0.26 & 0.01 \\
\hline Biggest unit for the money & 2.8 & 2.7 & -0.05 & 0.63 \\
\hline *Shopping areas within walking distance & 3.0 & 2.7 & -0.27 & $\mathbf{0 . 0 1}$ \\
\hline Good schools & 2.8 & 2.7 & -0.13 & 0.16 \\
\hline$*$ Parks and open space nearby & 2.7 & 2.6 & -0.10 & 0.34 \\
\hline I know the area & 2.8 & 2.6 & -0.23 & $\mathbf{0 . 0 1}$ \\
\hline Private yard & 2.7 & 2.6 & -0.09 & 0.32 \\
\hline Near family or friends & 2.6 & 2.6 & -0.03 & 0.81 \\
\hline Children's play areas & 2.4 & 2.3 & -0.06 & 0.56 \\
\hline *Easy access to a freeway & 2.2 & 2.2 & 0.02 & 0.87 \\
\hline$*$ Walking distance to schools & 2.2 & 2.1 & -0.12 & 0.25 \\
\hline *Places to eat in walking distance & 2.4 & 2.1 & -0.27 & 0.01 \\
\hline$*$ Access to bike routes & 2.0 & 1.7 & -0.23 & 0.04 \\
\hline
\end{tabular}

*Transportation related indicators; $\mathrm{N}=120$; Bold $=p<.1$

Before participants moved, we asked them if they intended to drive, walk, or use public transit more or less after moving. After moving, we asked them about their actual transportation behavior-whether they drove, walked, or used public transit more or less since they moved. Participants both believed that they would walk more in their new home and said that they actually did walk more after they had moved (See Table 4.7). However, participants said that their car and transit use generally stayed the same after moving. We then decided to see whether participants' transportation mode share changed from when they lived in their pre-move home to when they lived in their post-move home (See Table 4.8). Overall, the only mode of transportation that significantly changed after moving to a new home was transit use, which decreased. 
Table 4.7: Transportation Mode After Moving: Intention and Behavior

How much do you intend to walk, drive, and use transit after moving? (Pre-move)

How much do you walk, drive, and use transit compared to before moving? (Post-move)

$0=$ Decrease a lot; $2=$ Stay the same; $4=$ Increase a lot

\begin{tabular}{l|l|l|l|l}
\hline \multirow{2}{*}{ Variable } & All Groups & \multirow{2}{*}{ Difference } & \multirow{2}{*}{ Sig. } \\
\cline { 2 - 5 } & Pre-Move & Post-Move & & 0.32 \\
\hline Walking & 2.44 & 2.31 & -0.13 & 0.16 \\
\hline Transit & 2.20 & 1.99 & -0.22 & 0.14 \\
\hline Car & 1.77 & 1.99 & 0.22 & 0.22 \\
\hline
\end{tabular}

$\mathrm{N}=115 ;$ Bold $=p<.1$

Table 4.8: Transportation Mode Share Shift: Pre-Move Home and Post-Move Home

How much of your daily travel is by each of the following?

$0=$ None; 1 = A small amount; 2 = About half; $3=$ Most; $4=$ All

\begin{tabular}{l|l|l|l|l}
\hline \multirow{2}{*}{ Variable } & All Groups & \multirow{2}{*}{ Difference } & \multirow{2}{*}{ Sig. } \\
\cline { 2 - 5 } & Pre-Move & Post-Move & & 0.29 \\
\hline Walking & 1.38 & 1.51 & 0.14 & -0.22 \\
\hline Transit & 1.28 & 1.06 & 0.09 & 0.48 \\
\hline Car & 1.91 & 2.00 & 0.09 & 0.08 \\
\hline
\end{tabular}

$\mathrm{N}=115 ;$ Bold $=p<.1$ 


\subsection{DISCUSSION AND RECOMMENDATIONS}

\subsection{CONCLUSION}

The evaluation did not detect many significant differences between the outcomes of those who said that they remembered seeing the toolkit and those who did not. Those that were significant are as follows:

- Better access to transit in new home: Those who remembered seeing the toolkit moved to places which they found to have easier access to public transit stops by walking, while those who didn't remember the toolkit moved to places they found to have more difficult access.

- Lower housing costs: Those who remembered seeing the toolkit said that their housing costs decreased as a result of their move, while those who did not remember seeing the toolkit said that their housing costs increased. Both groups said that their transportation costs increased, and the difference between them was not significant.

It is not known whether those who remembered the toolkit moved to places with better public transit access intentionally, or whether it was an unplanned outcome of their move. And, while it is fortunate that people who remembered the toolkit found less expensive housing, reducing housing costs was not one of the goals of the toolkit; instead, it focused on ways to reduce transportation costs.

Thus, the evaluation resulted in little evidence to indicate that the toolkit can help the population of HCV participants, in general, move to housing with lower transportation costs in a very tight housing market. However, the toolkit might have greater relevance to HCV participants facing a move under different market conditions, when they have more choice about where to live. The toolkit most likely proved useful to some HCV participants (but not enough to show up statistically) during the very tight housing market. The toolkit may be more effective if it were introduced in a different manner, and if time were available to provide more staff assistance with researching housing options. Finally, the study overall produced interesting new information about how HCV participants make housing choices and the kinds of challenges they experience. Each of these topics is discussed in the sections below.

\subsubsection{Discussion}

This project took place in a time period of rapidly rising rents and low vacancy rates, especially for housing in desirable "walkable" neighborhoods. The scarcity of affordable rental housing was so severe by fall 2015 that the City of Portland declared a "Housing State of Emergency,” an unprecedented action for this community. Under these conditions, many HCV participants who needed to move found that their housing options were severely constrained, and thus may have been less choosey about where they moved and more likely to take one of the first places that accepted their application. Stated simply, if location-efficient housing within the right price range is not available, then the toolkit will be of little assistance. It is possible that, had the 
project occurred in a less constrained housing market, the toolkit may have been more impactful and the outcomes of the evaluation been different.

The type of evaluation used in this study parallels those used to test whether new drugs are effective for an identified population. The research question for this study was similar-does the toolkit work for the population of HCV participants seeking new housing? However, it would have been possible to reframe the central question into a series of questions, as follows:

- Was the toolkit useful to anyone?

- For whom was it useful? (shared characteristics)

o How was it useful?

0 What elements of it were useful?

- For whom was it not useful? (shared characteristics)

o Why was it not useful?

o Are there ways to change it or how it is provided to make it useful?

In retrospect, a revised research design might produce a more robust consideration of these questions. Instead of comparing outcomes of an Intervention Group to those of a Control Group, it could involve administering a brief survey before participants saw the toolkit and again after they moved, and then following up with telephone interviews or focus groups to obtain detailed, context-specific answers to the qualitative questions about why the toolkit was or was not useful.

This type of research design may be more suited to the dynamic nature of the setting for this project. This evaluation did not occur in a controlled, clinical setting. Instead, it involved use of the toolkit by already overburdened housing authority staff, some of whom questioned the usefulness of the project. It involved working in a busy environment-one with rising rents and administrative processes that changed to try to keep up with the market. Context matters, and while changes in the context have been documented in this study, we found no way to control for the changes statistically. Thus, the statistical analysis alone does not fully take into account the impacts of the dynamic setting. An approach that included a larger qualitative component could provide data to support an analysis that better explains and incorporates the impacts of the dynamic setting.

One of the limitations of this project is that it involved a single intervention-the provision of information and tools about location-efficient housing and the importance of considering transportation costs in the new home when looking for a place to live-and not systemic changes. Specifically, the project did not involve a comprehensive review of local housing authority administrative processes and policies, and the development and implementation of a suite of recommendations for changes to support location-efficient housing choices. The housing authorities did not have access to additional resources to implement such changes or to provide new resources to HCV participants. It is possible that additional interventions, such as the provision of subsidized or sliding-scale transit passes for recent movers or a reduction in the size of caseloads so that staff could work more intensively with participants in finding and securing location-efficient housing, in combination with the introduction of a new set of tools, could have resulted in stronger outcomes. 


\subsubsection{Key Findings}

This study generated information about HCV participants, their home search process and transportation-related behaviors, which may be useful to both the participating housing authorities and also researchers interested in the intersection of housing, transportation and behaviors of households with low incomes. Highlights include:

- Moving is both a vulnerable and pivotal life event for HCV participants. Because they have so much to lose if they do not find a new place to live, it is a highly stressful time. Failing to find a new home within the time limit could result in the loss of their housing voucher. If they lose their voucher, they face the possibility of doubling up with another household, living in substandard housing or even homelessness. On the other hand, moving to a better place can have a positive impact on health, well-being and access to opportunity.

- Moving is expensive. Focus group participants indicated that they had problems with recouping security deposits, and thus lacked resources for new security deposits for their new home. In addition, the cost of applications and background checks, utility hook-up fees and actual moving day expenses contributed to the high price of moving.

- In a tight rental market, most HCV participants who move do not do so by choice. Furthermore, we found that many of those moving of their own volition had already lined up new housing before they contacted the housing authority. A survey of movers conducted in July 2013 found that only 36\% — 40 of 110 movers-had given notice to their landlords voluntarily and were undecided about where they might move. Thus, one of the challenges for a toolkit intended to support location-efficient housing choices is finding a way to provide it to HCV participants when they are first considering a potential move.

- In everyday life, it is relatively easy to track monthly housing costs, but not transportation costs. This could obscure the importance and impact of location-efficient housing. Rent and utilities are each paid all at once. In contrast, most transportation costs (both time and money) are paid out throughout the month, in small increments, unless one purchases a monthly transit pass. Costs for gas, paying a neighbor for a ride and vehicle repair, for example, can add up to a substantial portion of household income, but be less tangible and visible than housing costs because they accrue over time. This “invisibility” of transportation costs can obscure the importance of finding a housing location that minimizes them.

- Even in a tight rental market, some prioritization of place occurs for some participants. The search method - for example, looking for a place to live by driving or walking around or using an online search tool that requires entry of a neighborhood or zip codemay prompt HCV participants to prioritize by place.

- While some HCV participants found that they benefitted from location-efficient neighborhoods, what seemed even more relevant were housing options nested in an individualized network of frequent destinations. Some destinations could not be replaced easily - for example, one's sister's home or one's place of work - while others, like a grocery store or pharmacy, could be replaced. Thus, tools which allow participants to identify housing options in an individualized "travel zone" (commuting area) may be particularly valuable. 
- HCV participants indicated that the most important factors in choosing a new home were feeling safe in the neighborhood, a well-maintained property and unit, a helpful property manager, and less expensive rent and utilities. Transportation-related considerations formed a second tier of factors and included low transportation costs, good public transportation, easy access to medical and social services, and the presence of sidewalks in the neighborhood.

\subsubsection{Additional Findings}

In addition, we would like to offer the following ideas for the housing authorities to consider:

- Each housing authority has a slightly different way of administering the HCV program. During Steering Committee meetings, representatives of the housing authorities had opportunities to learn from each other. Practices used by one housing authority were sometimes of interest to another. If this kind of informal information sharing among the region's housing authority staff does not already occur, it might be useful to consider it. For example, HAWC's method of enabling landlords to independently update their own entries on a live, online list of vacancies available on the HAWC website may be something that other housing authorities may wish to consider.

- An unexpected outcome of the HCV focus groups was that participants made the group session an opportunity to learn from each other. They shared their strategies for looking for housing and sources of assistance. In some cases, participants stayed after the focus group had formally ended to continue these discussions. Housing authorities may wish to consider including peer learning opportunities in their orientation sessions, such as a panel of recent movers or videotaped "testimonials."

\subsection{RECOMMENDATIONS}

The central messages of the toolkit remain relevant, and will become more so as the rental housing market improves. Thus, we encourage housing authorities to continue to incorporate the tools in their work with movers. The central messages are:

- When you choose a place to live, you're choosing more than a safe, affordable space for you and your family. You're also choosing how you will get around, and how much time and money you will spend getting around.

- In our area, transportation costs about 30\% of what families with housing assistance earn each month. For many, that's about as much as your housing costs.

- Unlike housing costs, transportation costs can sneak up on you. Most people know how much they pay for rent because it's paid all at once. But most people don't realize how much they spend on transportation, as the costs are paid gradually. Costs like gas, bus passes, car repairs and insurance all add up.

- What can you do about transportation costs?

o Think of the places where you go often. Then identify an area where you could get to your regular destinations in a reasonable amount of time and at a reasonable cost. This is your travel zone. Start your search for housing there.

o Compare not just places, but also commutes. 
o Think about other ways to travel. Consider whether transit, biking or walking, instead of driving, is reasonable.

- You may have challenges with finding a place to live, but a housing voucher expands your choices. Consider your transportation options and costs before you make a move.

Walk Score Apartment Finder, the online tool that can help HCV participants identify their travel zone and search for available rentals in that area, is updated by the owner on a regular basis. However, if Walk Score is discontinued or superseded by a different search engine with more relevant features, the toolkit would require significant revision. As long as Walk Score Apartment Finder remains useful, the video and checklist will not be out of date.

We encourage the housing authorities to continue providing access to the toolkit on their websites. The cost—in time and money—of doing so is relatively low, and the tools may be helpful to some HCV participants. We also encourage the housing authorities to continue to provide printed copies of the brochure, with links to the website where the complete toolkit can be found, in the informational packages of movers and wait list pulls who intend to move to different housing. Finally, we encourage the housing authorities to share the toolkit with service providers who work with HCV participants, as some may have smaller caseloads and more time to provide one-on-one assistance with finding a new home.

\subsection{TECHNOLOGY TRANSFER}

The last element of this project is to share the information and tools resulting from this project with local social service agency staff who can use them to assist their clients and with housing and transportation researchers who concerned with location-efficient housing for HCV participants.

The following tech transfer activities are being planned for January-March 2016:

- Presentations at meetings of local human service agencies in the Portland metro area to share the tools. Up to four presentations will be made, typically at a regular meeting of agency participants in a county's Continuum of Care network that serves homeless individuals and households.

- Webinar presentation for human service providers in the Portland region.

- Webinar presentation for a national audience of transportation and housing researchers and professionals. The focus will be on the research findings.

In addition, this project has resulted in the submission of a manuscript to the peer-reviewed journal Housing Policy Debate for a special issue on location efficiency. In response to feedback from reviewers, a revised manuscript was submitted in October 2015, and we await further word about its status. 


\subsection{REFERENCES}

Adkins, Arlie. "Determinants of Recent Mover Non-Work Travel Mode Choice.” Dissertations and Theses, August 13, 2014. http://pdxscholar.library.pdx.edu/open_access_etds/1919.

Ajzen, Icek. "From Intentions to Actions: A Theory of Planned Behavior.” In Action Control, edited by PD Dr Julius Kuhl and Dr Jürgen Beckmann, 11-39. SSSP Springer Series in Social Psychology. Springer Berlin Heidelberg, 1985. http://link.springer.com/chapter/10.1007/978-3642-69746-3_2.

Basolo, Victoria. "Examining Mobility Outcomes in the Housing Choice Voucher Program: Neighborhood Poverty, Employment, and Public School Quality.” Cityscape 15, no. 2 (January 1, 2013): 135-53.

Clampet-Lundquist, Susan. "Finding and Keeping Affordable Housing: Analyzing the Experiences of Single-Mother Families in North Philadelphia.” Journal of Sociology and Social Welfare 30, no. 4 (2003): 123-40.

Clark, Sherri. "Housing Instability: Toward a Better Understanding of Frequent Residential Mobility among America’s Urban Poor.” Washington, DC: Center for Housing Policy, 2010. http://www.nhc.org/media/files/LawsonClark_analysis_for_child_mobility.pdf.

Cunningham, Mary K, and Audrey Droesch. “Neighborhood Quality and Racial Segregation.” Washington, DC: Urban Institute, 2005. http://www.urban.org/publications/411248.html.

DeFilippis, James. “Commentary: On Spatial Solutions to Social Problems.” Cityscape 15, no. 2 (January 1, 2013): 69-72.

Devine, R, L Gray, and L Tahiti. "Housing Choice Voucher Location Patterns: Implications For Participant And Neighborhood Welfare.” Washington, DC: US Department of Housing and Urban Development, 2003. http://www.huduser.org/Publications/pdf/Location_Paper.pdf.

Ewing, Reid, and Robert Cervero. “Travel and the Built Environment.” Journal of the American Planning Association 76, no. 3 (2010): 265-94. doi:10.1080/01944361003766766.

Finkel, Meryl, and Larry Buron. "Study on Section 8 Voucher Success Rates. Volume I. Quantitative Study of Success Rates in Metropolitan Areas,” 2001.

http://www.huduser.org/portal/publications/pubasst/sec8success.html.

Fisher, Lynn M., Henry O. Pollakowski, and Jeffrey Zabel. “Amenity-Based Housing Affordability Indexes.” Real Estate Economics 37, no. 4 (December 1, 2009): 705-46. doi:10.1111/j.15406229.2009.00261.x. 
Haas, Peter, Carrie Makarewicz, Albert Benedict, and Scott Bernstein. "Estimating Transportation Costs by Characteristics of Neighborhood and Household.” Transportation Research Record: Journal of the Transportation Research Board 2077 (December 1, 2008): 62-70. doi:10.3141/2077-09.

Hickey, Robert, Jeffrey Lubell, Peter Haas, and Stephanie Morse. "Losing Ground: The Struggle of Moderate-Income Households to Afford the Rising Costs of Housing and Transportation.” Center for Housing Policy \& Center for Neighborhood Technology, October 2012. http://www.nhc.org/media/files/LosingGround_10_2012.pdf.

Levine, Jonathan, and Lawrence D. Frank. "Transportation and Land-Use Preferences and Residents' Neighborhood Choices: The Sufficiency of Compact Development in the Atlanta Region.” Transportation 34, no. 2 (November 2, 2006): 255-74. doi:10.1007/s11116-006-9104-6.

Litman, Todd. "Transportation Affordability: Evaluation and Improvement Strategies.” Victoria, Canada: Victoria Transport Policy Institute, 2013. http://www.vtpi.org/affordability.pdf.

Pendall, Rolf. "Why Voucher and Certificate Users Live in Distressed Neighborhoods.” Housing Policy Debate 11, no. 4 (January 1, 2000): 881-910. doi:10.1080/10511482.2000.9521391.

Scott, Molly, Mary Cunningham, Jennifer Biess, J O’Neil, P Tegeler, E Gayles, and B Sard. "Expanding Choice: Practical Strategies for Building a Successful Housing Mobility Program." Text. Urban Institute, February 15, 2013. http://www.urban.org/publications/412745.html.

Skobba, Kimberly, and Edward G. Goetz. "Mobility Decisions of Very Low-Income Households." Cityscape 15, no. 2 (January 1, 2013): 155-71.

Venkatesh, Sudhir. "Commentary: Acknowledging the Structural Features of Choice.” Cityscape 15, no. 2 (January 1, 2013): 211-14. 


\section{APPENDIX A}

\section{PROJECT TIMELINE}

\begin{tabular}{|c|c|c|c|c|c|c|c|c|c|c|c|c|}
\hline \multicolumn{13}{|c|}{2013} \\
\hline & Jan & Feb & Mar & Apr & May & June & July & Aug & Sept & Oct & Nov & Dec \\
\hline \multicolumn{13}{|c|}{ Phase 1: Tools } \\
\hline \multicolumn{13}{|c|}{ Best Practices Review } \\
\hline \multicolumn{13}{|c|}{ PHA Interviews } \\
\hline \multicolumn{13}{|c|}{$\begin{array}{l}\text { Participant Focus } \\
\text { Groups }\end{array}$} \\
\hline \multicolumn{13}{|c|}{ Tool Develop \& Train } \\
\hline \multicolumn{13}{|c|}{ Tool Deployment } \\
\hline \multicolumn{13}{|c|}{ Phase 2: Evaluation } \\
\hline \multicolumn{13}{|c|}{ Survey Development } \\
\hline \multicolumn{13}{|c|}{ Control Survey 1} \\
\hline \multicolumn{13}{|c|}{ Control Survey 2} \\
\hline \multicolumn{13}{|c|}{ Intervention Survey 1} \\
\hline \multicolumn{13}{|c|}{ Intervention Survey 2} \\
\hline \multicolumn{13}{|c|}{$\begin{array}{l}\text { Data Entry \& } \\
\text { Cleaning }\end{array}$} \\
\hline \multicolumn{13}{|l|}{ Analysis } \\
\hline Report & & & & & & & & & & & & \\
\hline
\end{tabular}

\begin{tabular}{|c|c|c|c|c|c|c|c|c|c|c|c|c|}
\hline \multicolumn{13}{|c|}{2014} \\
\hline & Jan & Feb & Mar & Apr & May & June & July & Aug & Sept & Oct & Nov & Dec \\
\hline \multicolumn{13}{|c|}{ Phase 1: Tools } \\
\hline \multicolumn{13}{|c|}{ Best Practices Review } \\
\hline \multicolumn{13}{|c|}{ PHA Interviews } \\
\hline \multicolumn{13}{|c|}{$\begin{array}{l}\text { Participant Focus } \\
\text { Groups }\end{array}$} \\
\hline \multicolumn{13}{|c|}{ Tool Develop \& Train } \\
\hline \multicolumn{13}{|c|}{ Tool Deployment } \\
\hline \multicolumn{13}{|c|}{ Phase 2: Evaluation } \\
\hline \multicolumn{13}{|c|}{ Survey Development } \\
\hline \multicolumn{13}{|c|}{ Control Survey 1} \\
\hline \multicolumn{13}{|c|}{ Control Survey 2} \\
\hline \multicolumn{13}{|c|}{ Intervention Survey 1} \\
\hline \multicolumn{13}{|c|}{ Intervention Survey 2} \\
\hline \multicolumn{13}{|c|}{$\begin{array}{l}\text { Data Entry \& } \\
\text { Cleaning }\end{array}$} \\
\hline \multicolumn{13}{|c|}{ Analysis } \\
\hline Report & & & & & & & & & & & & \\
\hline
\end{tabular}




\begin{tabular}{|c|c|c|c|c|c|c|c|c|c|c|c|c|}
\hline \multicolumn{13}{|c|}{2015} \\
\hline & Jan & Feb & Mar & Apr & May & June & July & Aug & Sept & Oct & Nov & Dec \\
\hline \multicolumn{13}{|c|}{ Phase 1: Tools } \\
\hline \multicolumn{13}{|c|}{ Best Practices Review } \\
\hline \multicolumn{13}{|c|}{ PHA Interviews } \\
\hline \multicolumn{13}{|c|}{$\begin{array}{l}\text { Participant Focus } \\
\text { Groups }\end{array}$} \\
\hline \multicolumn{13}{|c|}{ Tool Develop \& Train } \\
\hline \multicolumn{13}{|c|}{ Tool Deployment } \\
\hline \multicolumn{13}{|c|}{ Phase 2: Evaluation } \\
\hline \multicolumn{13}{|c|}{ Survey Development } \\
\hline \multicolumn{13}{|c|}{ Control Survey 1} \\
\hline \multicolumn{13}{|c|}{ Control Survey 2} \\
\hline \multicolumn{13}{|c|}{ Intervention Survey 1} \\
\hline \multicolumn{13}{|c|}{ Intervention Survey 2} \\
\hline \multicolumn{13}{|c|}{$\begin{array}{l}\text { Data Entry \& } \\
\text { Cleaning }\end{array}$} \\
\hline \multicolumn{13}{|l|}{ Analysis } \\
\hline Report & & & & & & & & & & & & \\
\hline
\end{tabular}

\section{Key Dates}

- Project Period: April 1, 2013 through December 31, 2015

- Tool Deployment: April 1, 2014. Tools made public in April 2015.

- Recruitment Period for Control Group: December 2013 through March 2014 (Survey 1); Survey 2 distribution concluded in March 2015.

- Recruitment Period for Intervention Group: April 2014 through December 2014 for Home Forward (Survey 1); April 2014 through February 2015, HAWC, HACC and VHA (Survey 1). Survey 2 distribution concluded July 15, 2015. 


\section{APPENDIX B-1 \\ PROTOCOLS FOR HOUSING AUTHORITY STAFF INTERVIEWS}

Purpose: To gain information about how each PHA administers the Housing Choice Voucher program and the assistance provided to participants currently, so that mobility tools will build upon current practices and processes.

Suggestions for Participants: supervisor, someone who works with participants, data person. Sequential meetings possible.

\section{Dates}

Tuesday, May 21, 2013 9:30 - 12 noon: Housing Authority of Clackamas County

- Mary-Rain O’Meara

- Toni Carter, Section 8 Housing Services Manager

- Debbie Greene, Eligibility Specialist

- Address: 13930 S. Gain Street, Oregon City, OR

Wednesday, May 22, 2013 1:30 PM to 4:00 PM: Home Forward

- Rebecca Nesbit

- Myriam Demezas

- Address: 135 SW Ash, Portland OR 97204

Wednesday, May 29, 2013 9:30 to 12 noon: Vancouver Housing Authority

- Sasha Nichelson, Director of Voucher Programs

- Misty Collard, Voucher Specialist II

- Jan Wichert, Director Resident and Employee Services

- Address: 2500 Main Street, Vancouver, WA 98660

Friday, May 31, 2013 9:30 to 12 noon: Housing Authority of Washington County

- Kim Armstrong

- Melanie Fletcher

- Address: 111 NE Lincoln Street, Hillsboro, OR 97124

Preparation: Please review the topics below and gather any written materials that might be useful to the consulting team.

Topics to be Discussed: The list below provides a jumping off-point for our discussion. We are happy to add additional ones that you recommend.

General Orientation to your program 
- Scope and scale of your voucher program-types of vouchers, programs, etc.

- Staff structure and roles for your voucher program

Trigger Points for Mobility Project Participants

- "Sources" of potential participants

- Estimated number of participants in each

- Special characteristics, if any

- Demographic information about participants and wait list candidates---profile

Step-by-Step Description of Process from Intake/Orientation to Post-Move Support

- From participant's point of view, steps in the process

o PHA interactions with participants — nature, extent, timing, etc.

o Copies of materials

- Variations for people entering from specific trigger points

- How do participants find housing currently? Do you maintain listings?

Local Policies

- Lease-up period

- Payment standards for landlords (any variations)

- Occupancy/subsidy standards for residents

- Landlord recruitment, support, inducements

- Portability

- Housing Quality Standards administration—initial inspections, self-certifications for minor repairs

- Impacts of sequestration

- Others?

Location-Efficient Housing Availability

- Housing market—availability of units, rents, etc.

- Where do most of your voucher households access housing currently? (Map? List by CT/BG? Addresses??)

- How do you define location-efficient housing?

- Where do you think the most location-efficient housing can be found?

- Barriers to accessing location-efficient housing

Barriers to using alternative transportation modes currently

Ideas About Learning Method Options

- Based on your experience, what methods are effective?

- Individual vs. group

- In person vs. on one's own

- Phone vs. mail

- Languages

- Literacy

- Web access/computer literacy of your participants 
Data

- Unique number identifier for each participant?

- What demographic data do you collect about participants?

- In process, what do you track currently about each participant's participation in program activities?

Participant Focus groups_-advice

- Topics

- Incentives

- Location

Anything else you would like to tell us about internal or external factors affecting your voucher program? 


\section{APPENDIX B-2}

PHA POLICIES AND PROCEDURES

\begin{tabular}{|c|c|c|c|c|}
\hline \multicolumn{5}{|c|}{$\begin{array}{l}\text { Summary of Findings from Interviews with Housing Authority Staff About Housing Choice Voucher } \\
\text { Program }\end{array}$} \\
\hline & Home Forward & $\begin{array}{l}\text { Housing Authority of } \\
\text { Clackamas County }\end{array}$ & $\begin{array}{l}\text { Housing Authority of } \\
\text { Washington County }\end{array}$ & $\begin{array}{c}\text { Vancouver Housing } \\
\text { Authority }\end{array}$ \\
\hline \multicolumn{5}{|c|}{ Potential Sources of Mobility Program Participants } \\
\hline $\begin{array}{l}\text { Transfers (annually)-- } \\
\text { Also called "moves" }\end{array}$ & $\begin{array}{l}789 \text { (fewer anticipated } \\
\text { this coming year) }\end{array}$ & $\begin{array}{l}220 \text { (last year was } 108 \text {, } \\
\text { which was lower than } \\
\text { normal) }\end{array}$ & 231 & 262 \\
\hline Port-Ins (annually) & 161 & 25 & 157 & 121 \\
\hline $\begin{array}{l}\text { Waiting List Pulls } \\
\text { (annually) }\end{array}$ & $\begin{array}{l}\text { None-Sequestration } \\
\text { Impacts }\end{array}$ & $\begin{array}{l}\text { None-Sequestration } \\
\text { Impacts }\end{array}$ & 5 & $\begin{array}{l}\text { None-Sequestration } \\
\text { Impacts }\end{array}$ \\
\hline Conclusion & \multicolumn{4}{|c|}{ Focus on transfers for research. } \\
\hline \multicolumn{5}{|c|}{ Rental Housing Market Conditions--How Easy Is It to Find Housing? } \\
\hline $\begin{array}{l}\text { Vacancy Rates Spring } \\
2013 \\
\text { Multi-family listings } \\
\text { only } \\
\text { Source: MMHA, as reported in } \\
\text { Center for Real Estate Quarterly, } \\
\text { Vol. 7, No.2, Spring } 2013\end{array}$ & $\begin{array}{l}\text { 3.9\% Inner/Central NE } \\
\text { 3.7\% Outer NE } \\
\text { 3.5\% Gresham area } \\
\text { 3.4\% Downtown PDX } \\
\text { 3.3\% NW PDX } \\
\text { 2.9\% Inner \& Central } \\
\text { SE } \\
\text { 2.8\% Outer SE } \\
\text { 2.5\% North Portland }\end{array}$ & $\begin{array}{l}\text { 5.4\% Lake } \\
\text { Oswego/West Linn } \\
3.8 \% \\
\text { Wilsonville/Canby } \\
\text { 3.7\% Oregon } \\
\text { City/Glad-stone } \\
\text { 3.1\% Milwaukie }\end{array}$ & $\begin{array}{l}\text { 5.7\% Hillsboro } \\
3.7 \% \text { Aloha } \\
3.7 \% \text { Beaverton } \\
2.7 \% \\
\text { Tigard/Tualatin/Sher- } \\
\text { wood }\end{array}$ & $\begin{array}{l}\text { 3.4\% East Vancouver } \\
\text { 3.4\% West Vancouver } \\
\text { Note: Does not include } \\
\text { single-family rentals, a } \\
\text { major source of housing } \\
\text { for voucher-holders in } \\
\text { Clark County }\end{array}$ \\
\hline PHA Staff Observations & $\begin{array}{l}\text { Very tight rental market, } \\
\text { especially for voucher- } \\
\text { holders. Hard to find } \\
\text { housing in close-in } \\
\text { Portland neighborhoods. } \\
\text { Most popular places for } \\
\text { families are along }\end{array}$ & $\begin{array}{l}\text { About } 40 \% \text { of voucher } \\
\text { holders live in } \\
\text { Milwaukie, and Oregon } \\
\text { city and Gladstone are } \\
\text { also popular. } \\
\text { Wilsonville had } \\
\text { significant gains in the }\end{array}$ & $\begin{array}{l}\text { Low vacancy rates and } \\
\text { high rents can make } \\
\text { locating appropriate } \\
\text { housing in Washington } \\
\text { county challenging }\end{array}$ & $\begin{array}{l}\text { Rental market not seen } \\
\text { as much of a problem in } \\
\text { Clark County. Clients } \\
\text { can find housing, often } \\
\text { have choices, including } \\
\text { some rentals of single- } \\
\text { family detached homes. }\end{array}$ \\
\hline
\end{tabular}




\begin{tabular}{|c|c|c|c|c|}
\hline & $\begin{array}{l}\text { frequent bus and MAX } \\
\text { lines in outer east } \\
\text { Multnomah County and } \\
\text { Gresham, other cities in } \\
\text { east. Access to services } \\
\text { \& transit makes } \\
\text { downtown desirable } \\
\text { location for some } \\
\text { elderly \& disabled. }\end{array}$ & $\begin{array}{l}\text { number of voucher } \\
\text { holders last year. } \\
\text { Approximately } 15 \% \text { to } \\
\text { 20\% live in tax credit } \\
\text { properties. }\end{array}$ & & \\
\hline $\begin{array}{l}\text { Annual Port-In / Port- } \\
\text { Out Ratio (excluding } \\
\text { exchanges between HF } \\
\text { \& HACC) }\end{array}$ & $\begin{array}{l}\text { Approximately } 161 / 144 \\
=1.12 \text { Port-ins exceed } \\
\text { port-outs }\end{array}$ & $\begin{array}{l}\text { Approximately } 76 / 66= \\
1.15 \text { Port-ins exceed } \\
\text { port-outs. }\end{array}$ & $\begin{array}{l}\text { Approximately } 157 / 66= \\
2.38 \text { Port-ins exceed } \\
\text { port-outs }\end{array}$ & $\begin{array}{l}\text { Approximately } 121 / 34 \\
=3.56 \text { Port-ins exceed } \\
\text { port-outs }\end{array}$ \\
\hline $\begin{array}{l}\text { Current voucher } \\
\text { utilization rate }\end{array}$ & $99 \%$ & $\begin{array}{l}\text { Dropping due to } \\
\text { Sequestration, was at } \\
99 \% \text { now dropping to } \\
95 \%\end{array}$ & Close to $100 \%$ & $92 \%$ \\
\hline Conclusion & \multicolumn{4}{|c|}{$\begin{array}{l}\text { Market conditions vary across the region, but vacancy rate appears to be below } 5 \% \text { almost everywhere. } \\
\text { Very difficult to find affordable close-in housing in Portland or rental housing in high opportunity areas } \\
\text { like Lake Oswego or West Linn. Clark County staff indicated that there are more affordable housing } \\
\text { opportunities (including single-family detached housing) in Clark County. }\end{array}$} \\
\hline \multicolumn{5}{|c|}{ Opportunity-Rich, Location-Efficient Housing } \\
\hline Where is it? & $\begin{array}{l}\text { For some } \\
\text { disabled/elderly needing } \\
\text { services: downtown } \\
\text { Portland. } \\
\text { For families_-see maps. } \\
\text { Higher rents and low- } \\
\text { poverty areas. }\end{array}$ & $\begin{array}{l}\text { Milwaukie-schools, } \\
\text { hospital, services, but } \\
\text { little employment. } \\
\text { Wilsonville-better } \\
\text { employment } \\
\text { opportunities. } \\
\text { Mass transit not easily } \\
\text { accessible throughout } \\
\text { county. Car ownership } \\
\text { lower among voucher } \\
\text { holders than among }\end{array}$ & $\begin{array}{l}\text { Along MAX route, near } \\
\text { public transportation, } \\
\text { near Sunset corridor. }\end{array}$ & $\begin{array}{l}\text { Very difficult to } \\
\text { identify places that are } \\
\text { opportunity-rich and } \\
\text { have good transit. } \\
\text { High-income places } \\
\text { often lack access to key } \\
\text { services (like grocery } \\
\text { stores) that people need. }\end{array}$ \\
\hline
\end{tabular}




\begin{tabular}{|c|c|c|c|c|}
\hline & & $\begin{array}{l}\text { Public Housing } \\
\text { residents. }\end{array}$ & & \\
\hline Barriers to accessing it & Cost, availability & $\begin{array}{l}\text { Shortage of affordable } \\
\text { rental housing in Lake } \\
\text { Oswego and West Linn. } \\
\text { Also, staff indicated } \\
\text { that some clients do not } \\
\text { move there because } \\
\text { they do not feel } \\
\text { comfortable there. }\end{array}$ & High rents, low vacancy & $\begin{array}{l}\text { Not sure where it is or if } \\
\text { it exists. New report on } \\
\text { social determinants of } \\
\text { health may be useful. }\end{array}$ \\
\hline Conclusion & \multicolumn{4}{|c|}{$\begin{array}{l}\text { The concept of what constitutes opportunity-rich housing and location-efficient housing varies quite a bit } \\
\text { from PHA to PHA. Among the four counties, there are distinctly different urban forms and transit } \\
\text { opportunities. } \\
\text { Recommendation: Should discuss these issues further at a future Steering Committee meeting to get } \\
\text { clearer understanding of project goals and what is realistic, given this varied landscape. }\end{array}$} \\
\hline \multicolumn{5}{|c|}{ Client Choices Around Moving } \\
\hline Why do they move? & $\begin{array}{l}\text { If voluntary, usually } \\
\text { because they want a } \\
\text { better unit, better } \\
\text { neighborhood, and/or } \\
\text { more affordable } \\
\text { situation. If involuntary, } \\
\text { because landlord issues } \\
\text { a No Cause or For } \\
\text { Cause Termination } \\
\text { notice or has proceeded } \\
\text { with the eviction } \\
\text { process. }\end{array}$ & $\begin{array}{l}\text { Voluntary movers move } \\
\text { to find cheaper housing } \\
\text { or because their family } \\
\text { size or job location } \\
\text { changes. }\end{array}$ & $\begin{array}{l}\text { Half or more are moving } \\
\text { of their own volition. } \\
\text { Opening of a new tax } \\
\text { credit projects near } \\
\text { transit often prompts } \\
\text { moves. }\end{array}$ & $\begin{array}{l}\text { Household size change. } \\
\text { To avoid trouble with } \\
\text { landlord. }\end{array}$ \\
\hline $\begin{array}{l}\text { When do they choose } \\
\text { housing? }\end{array}$ & $\begin{array}{l}\text { Voluntary moves-most } \\
\text { have place in mind. } \\
\text { Fewer clients coming in } \\
\text { without place in mind. }\end{array}$ & $\begin{array}{l}\text { Usually have housing } \\
\text { chosen before } \\
\text { orientation session. } \\
\text { Clients nervous about } \\
\text { initiating the process }\end{array}$ & $\begin{array}{l}\text { Most voluntary movers } \\
\text { have a unit in mind } \\
\text { when they move. }\end{array}$ & $\begin{array}{l}\text { Most clients find a } \\
\text { place to rent before } \\
\text { contacting the } \\
\text { Vancouver Housing } \\
\text { Authority. }\end{array}$ \\
\hline
\end{tabular}




\begin{tabular}{|c|c|c|c|c|}
\hline & $\begin{array}{l}\text { Evictions/terminations } \\
\text { of tenancy-most do not } \\
\text { have place in mind, but } \\
\text { they are anxious to find } \\
\text { housing, and some may } \\
\text { have negative rental } \\
\text { history }\end{array}$ & $\begin{array}{l}\text { and giving 30-day } \\
\text { notice to landlord } \\
\text { without having another } \\
\text { place chosen. }\end{array}$ & & \\
\hline $\begin{array}{l}\text { How much assistance } \\
\text { does PHA provide in } \\
\text { locating housing? }\end{array}$ & $\begin{array}{l}\text { Information about } \\
\text { independent listing } \\
\text { services, PHA- } \\
\text { maintained listings. }\end{array}$ & $\begin{array}{l}\text { PHA-maintained } \\
\text { listings-staff call } \\
\text { landlords weekly and } \\
\text { update listings weekly; } \\
\text { posted online. Also, } \\
\text { information provided } \\
\text { about independent } \\
\text { third-party listing } \\
\text { services in packet and } \\
\text { online. }\end{array}$ & $\begin{array}{l}\text { PHA-maintained listings } \\
\text { on website and available } \\
\text { hard copy in lobby. } \\
\text { Note: Landlords are } \\
\text { able to update their own } \\
\text { listings online in } \\
\text { Washington County- } \\
\text { thus online version } \\
\text { continually updated. } \\
\text { Also links on website to } \\
\text { third-party sites }\end{array}$ & $\begin{array}{l}\text { Referred to } \\
\text { Section8.com or } \\
\text { craigslist.com. VHA } \\
\text { does not maintain list. }\end{array}$ \\
\hline Conclusion & \multicolumn{4}{|c|}{$\begin{array}{l}\text { Significant concern: In general, most voluntary movers have already chosen where they want to move } \\
\text { before they make first contact (by phone) with PHA staff. Involuntary movers--those with evictions or } \\
\text { issues with rental history-face a very short time frame to find housing and may take first place that will } \\
\text { accept them (limited choice further minimized). } \\
\text { Best Practice Opportunity: Washington County has automated its online listings so that landlords can } \\
\text { update availability online. }\end{array}$} \\
\hline \multicolumn{5}{|c|}{ Process for Transfers and Port-Ins } \\
\hline Transfers--Step-by-step & $\begin{array}{l}\text { 1. Client initiates } \\
\text { contact, usually by } \\
\text { phone. Or landlord } \\
\text { submits copy of } \\
\text { Notice to Vacate } \\
\text { issued to their } \\
\text { tenant. }\end{array}$ & $\begin{array}{l}\text { 1. Client initiates } \\
\text { contact, usually by } \\
\text { phone. } \\
\text { 2. Voluntary movers } \\
\text { issues 30-day notice } \\
\text { to landlord. } \\
\text { 3. Clients provide } \\
\text { copy of 30-day }\end{array}$ & $\begin{array}{l}\text { 1. Client initiates } \\
\text { contact, usually by } \\
\text { phone. } \\
\text { 2. Client comes in with } \\
\text { copy of } 30 \text { day } \\
\text { notice to meet with } \\
\text { case worker, who } \\
\text { prepares move }\end{array}$ & $\begin{array}{l}\text { 1. Client initiates } \\
\text { contact, usually by } \\
\text { phone. } \\
\text { 2. Clients try to find } \\
\text { housing on } \\
\text { Section8.com or } \\
\text { craigslist.com }\end{array}$ \\
\hline
\end{tabular}




\begin{tabular}{|c|c|c|c|c|}
\hline & $\begin{array}{l}\text { 2. PHA sends transfer } \\
\text { packet, which } \\
\text { includes income } \\
\text { certification } \\
\text { information, 30-day } \\
\text { notice of intent to } \\
\text { vacate. } \\
\text { 3. When packet is } \\
\text { complete, PHA staff } \\
\text { schedules meeting } \\
\text { with participant. } \\
\text { 4. Individual meeting, } \\
\text { 30 minutes to } 1 \\
\text { hour. Extensive } \\
\text { handouts, specific } \\
\text { forms, etc. Housing } \\
\text { voucher is signed at } \\
\text { meeting and 60-day } \\
\text { clock begins. }\end{array}$ & $\begin{array}{l}\text { notice or } \\
\text { termination of } \\
\text { tenancy notice to } \\
\text { HACC, and then } \\
\text { they can sign up for } \\
\text { class. } \\
\text { 4. } 2 \text { - } 3 \text { classes held } \\
\text { per month, with 3- } \\
20 \text { clients. Very } \\
\text { organized } \\
\text { information } \\
\text { package-includes } \\
\text { resources as well as } \\
\text { required forms. Two } \\
\text { hours. Clients } \\
\text { required to submit } \\
\text { new income } \\
\text { certification } \\
\text { information. } \\
\text { 5aterials exchanged } \\
\text { via mail or drop-off. }\end{array}$ & $\begin{array}{l}\text { paperwork. No } \\
\text { moving packet. } \\
\text { 3. New income } \\
\text { verification occurs at } \\
\text { move-must fill out } \\
\text { paperwork. } \\
\text { Note: Port-ins also } \\
\text { attend a briefing to } \\
\text { familiarize them with } \\
\text { HAWC processes and } \\
\text { procedures. }\end{array}$ & $\begin{array}{l}\text { 3. VHA prepares a } \\
\text { rent estimate letter. } \\
\text { No new income } \\
\text { verification } \\
\text { required. } \\
\text { 4. Rent estimate letter } \\
\text { mailed with } \\
\text { landlord notice } \\
\text { form. } \\
\text { 5. When they return } \\
\text { paperwork from } \\
\text { new landlord, } \\
\text { voucher can be } \\
\text { issued in a few } \\
\text { days. }\end{array}$ \\
\hline $\begin{array}{l}\text { Transfers--Staff-client } \\
\text { contact }\end{array}$ & $\begin{array}{l}\text { One-on-one meeting } \\
\text { (about } 30-60 \text { minutes) } \\
\text { and communications by } \\
\text { phone and mail. }\end{array}$ & Two hour small class. & $\begin{array}{l}\text { Individual meeting and } \\
\text { communications by } \\
\text { phone and e-mail as } \\
\text { needed. }\end{array}$ & No in-person contact. \\
\hline Port-Ins & $\begin{array}{l}\text { Go to general } \\
\text { orientation for new } \\
\text { voucher-holders }\end{array}$ & Did not discuss. & Invited to a briefing. & Not discussed \\
\hline Conclusion & $\begin{array}{l}\text { - Significant varia } \\
\text { for transfers (mo } \\
\text { PHAs difficult. } \\
\text { - } \quad \text { May be very dif }\end{array}$ & $\begin{array}{l}\text { s among housing autho } \\
\text { may make a single, un } \\
\text { t to randomly assign cl }\end{array}$ & $\begin{array}{l}\text { ties in procedures and le } \\
\text { ied approach to incorpor } \\
\text { nts to a control group }\end{array}$ & $\begin{array}{l}\text { ature of client contact } \\
\text { vouchers across all }\end{array}$ \\
\hline
\end{tabular}




\begin{tabular}{|c|c|c|c|c|}
\hline Moving to Work PHA & Yes & No & No & Yes \\
\hline Payment Standards & $\begin{array}{l}3 \text { for Multnomah } \\
\text { County- (1 \& } 2 \text { BR } \\
\text { only) } \\
2 \text { for Clackamas County }\end{array}$ & $\begin{array}{l}2 \text { for Clackamas County } \\
3 \text { for Multnomah } \\
\text { County- } \\
\text { (1 \& } 2 \text { BR only) }\end{array}$ & $\begin{array}{l}\text { Single payment standard } \\
\text { for county. }\end{array}$ & $\begin{array}{l}\text { Single payment } \\
\text { standard for county. }\end{array}$ \\
\hline Occupancy Standards & $\begin{array}{l}\text { No adjustments for age } \\
\text { or sex }\end{array}$ & $\begin{array}{l}\text { Changing to No } \\
\text { adjustments for age or } \\
\text { sex }\end{array}$ & $\begin{array}{l}\text { Adjustments for age and } \\
\text { sex of children (more } \\
\text { generous) }\end{array}$ & $\begin{array}{l}\text { No adjustments for age } \\
\text { or sex }\end{array}$ \\
\hline $\begin{array}{l}\text { Share of income for } \\
\text { housing \& utilities }\end{array}$ & $30 \%$ to $70 \%$ & $30 \%$ to $40 \%$ & Did not record answer. & $30 \%$ to $40 \%$ \\
\hline $\begin{array}{l}\text { Can vouchers overlap } \\
\text { during moves? }\end{array}$ & $\begin{array}{l}\text { No - payment in new } \\
\text { place begins: day after } \\
\text { unit passes inspection, } \\
\text { day lease is signed, or } \\
\text { day after move out date } \\
\text { of previous place, } \\
\text { whichever is later. }\end{array}$ & No & No & Yes \\
\hline Lease-up time period & $\begin{array}{l}60+30+30-\text { given } \\
\text { current market, may } \\
\text { grant extensions beyond } \\
120 \text { days }\end{array}$ & 60 days. & $\begin{array}{l}60 \text { days. Extensions can } \\
\text { be requested but not } \\
\text { automatically provided. }\end{array}$ & $\begin{array}{l}60 \text { days, automatically } \\
\text { extended to } 90.120- \\
180 \text { as a reasonable } \\
\text { accommodation. }\end{array}$ \\
\hline $\begin{array}{l}\text { Information provided to } \\
\text { residents about housing }\end{array}$ & $\begin{array}{l}\text { Maintains listings of } \\
\text { available units, updated } \\
\text { weekly }\end{array}$ & $\begin{array}{l}\text { Maintains listings of } \\
\text { available housing, } \\
\text { updated weekly. Staff } \\
\text { updates by calling } \\
\text { landlords weekly. }\end{array}$ & $\begin{array}{l}\text { Maintains listings of } \\
\text { available housing, } \\
\text { updated at least weekly. } \\
\text { Landlords can update } \\
\text { online }\end{array}$ & $\begin{array}{l}\text { Does not maintain } \\
\text { listings of available } \\
\text { housing. Refers people } \\
\text { to Section8.com or } \\
\text { craigslist.com }\end{array}$ \\
\hline Outreach to landlords & $\begin{array}{l}\text { Mostly led by clients } \\
\text { Brochure describes } \\
\text { incentives: } \\
\text { - Multiple payment } \\
\text { standards }\end{array}$ & $\begin{array}{l}\text { Mass mailing to Lake } \\
\text { Oswego and West Linn } \\
\text { landlords when they } \\
\text { began two payment } \\
\text { standards. Biannual } \\
\text { workshops; Fair } \\
\text { Housing is popular }\end{array}$ & $\begin{array}{l}\text { Quarterly landlord } \\
\text { forums. Some (Fair } \\
\text { Housing Training) very } \\
\text { well-attended. }\end{array}$ & None discussed. \\
\hline
\end{tabular}




\begin{tabular}{|c|c|c|c|c|}
\hline & $\begin{array}{ll}\text { - } & \text { \$100 incentive } \\
& \text { payment per unit for } \\
& \text { low poverty areas } \\
\text { - } & \text { Guarantee fund for } \\
& \text { repairs } \\
\text { - } & \text { 6-month initial lease } \\
\text { - } & \text { Direct deposit of } \\
& \text { payment } \\
\end{array}$ & $\begin{array}{l}\text { topic. Occasional } \\
\text { mailings }\end{array}$ & & \\
\hline $\begin{array}{l}\text { Other relevant } \\
\text { policy/organizational } \\
\text { issues }\end{array}$ & 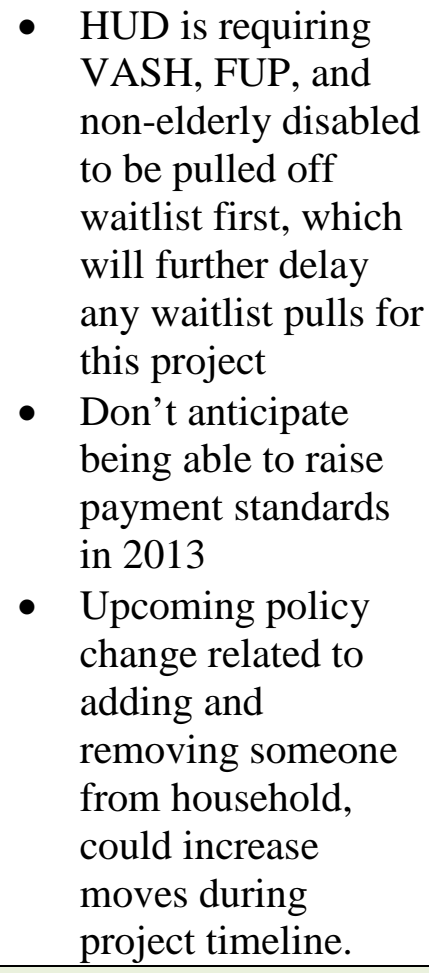 & $\begin{array}{l}\text { Board of County } \\
\text { Commissioners has } \\
\text { established committee } \\
\text { to study future of } \\
\text { HACC. Independent } \\
\text { institutional audit } \\
\text { underway. } \\
\text { Due to budget cuts, } \\
\text { culture shift away from } \\
\text { providing personalized } \\
\text { assistance to clients to } \\
\text { more self-help with } \\
\text { guidance. }\end{array}$ & $\begin{array}{l}\text { Managing sequestration } \\
\text { impacts by carefully } \\
\text { issuing new vouchers as } \\
\text { appropriate. }\end{array}$ & $\begin{array}{l}\text { New imputed income } \\
\text { policy ( } \$ 9,000 / \text { year }) \\
\text { for work-able clients } \\
\text { goes into effect June } 1 . \\
\text { May dampen number of } \\
\text { port-ins. } \\
\text { Emphasis is on choice } \\
\text { in Housing Choice } \\
\text { vouchers; oriented } \\
\text { toward self-help by } \\
\text { clients. }\end{array}$ \\
\hline Conclusion & & & & \\
\hline
\end{tabular}




\section{APPENDIX B-3}

\section{INSTRUCTIONS TO HOUSING AUTHORITIES REGARDING RECRUITMENT OF FOCUS GROUP PARTICIPANTS}

Purpose: The purpose of the focus groups is to learn about how voucher holders find their housing (both what they do and the factors that they consider) and to explore what kinds of information and assistance would be helpful to facilitate moves to higher-opportunity areas.

Proposed dates: July 29 - August 1 and August 5-6. Please schedule when most convenient for participants, evenings included.

Design of Focus Groups: Home Forward: One general population focus group, one special population focus group. Clackamas, Clark and Washington Counties: one focus group each. Possibly one additional focus group which may be conducted in another language by a volunteer trained by your PSU team. $5-6$ focus groups total.

Location and Length: The focus groups will last for two hours or less (15 minutes allowed for participants arriving late, etc., then about 90 minutes of discussion). They will occur at places designated by the PHAs. We will need to have internet access and access to a projector, laptop, and wall or space to project on so that we can preview some of the potential tools with the participants. The sites should be convenient to participants and have a quiet room with a table and enough chairs for everyone to sit. Light refreshments will be provided by PSU team. We will need to access and set up the room about 30 minutes prior to the start of the focus groups.

Participants: Current voucher holders who have moved within the last 12 months, including new participants who moved as a result of obtaining a voucher.

In selecting whom to invite, consider two (often contradictory) factors:

- Focus groups work best if people feel comfortable with the others who are participating. In general, this is most likely to occur if the participants do not know each other but feel that the other people in the room are similar to themselves in some way that enables them to open up.

- It will be helpful to include people from a variety of backgrounds so that we get the broadest possible understanding of the experiences of voucher holders in your community.

Each focus group should have approximately eight participants, so you will need to recruit about 12 or more people to ensure that enough will show up the day of the event.

Recruitment: PHAs to recruit participants. You may send out a letter and/or contact by phone- see attached texts for sample content. We strongly suggest calling people the day before or day of the event to remind them about it. 
Confidentiality: The focus groups will be confidential. The PSU research team does not need to know the full name of anyone participating in the focus groups. During the focus groups themselves, we will request that the participants not share information that participants provide during the focus group with others---a "what is said in the room stays in the room" ground rule. While it may be helpful for PHA staff to greet participants, PHA staff should not plan to sit in on the focus groups, as the absence of PHA staff may help create an environment where the participants will be forthcoming with critical or sensitive information useful to the project.

The PSU team will audio-record and transcribe the focus groups and produce a summary report that will present key findings, noting broad patterns of convergence and divergence among the groups. The PSU team will provide the summary report, but not the recordings or transcripts, to the PHA staff.

In the very unlikely event that a suspected instance of child abuse surfaces during the focus groups, PSU staff is required to report it. PSU will first notify the relevant PHA Steering Committee member and then the appropriate authorities. PSU staff will not report instances of potential violations of PHA policies or illegal activities (other than child abuse) that surface during the focus groups. We do not anticipate that this kind of information will be shared by the participants. 


\section{Sample Script for Housing Authority Staff to Recruit Focus Group Participants}

Hi, [participant]. This is [PHA staff] calling from the [agency name].

I’m calling to invite you to group discussion. We are working with some researchers from Portland State University to help us study how voucher holders look for and find their homes. So we are inviting people like you, who have moved in the last year, to participate. We want to learn from your experience and strengthen our services. It's completely voluntary. Whether or not you choose to participate will not affect your voucher or anything here at the housing authority. Is this something that might interest you?

So, here are the details-

[Date, time and location]

As a way of thanking you for your time, we'll provide [supper-some sandwiches or whatever is decided]. And at the end of the group meeting-we are aiming for about eight to twelve people - there will be a raffle for a $\$ 25$ gift certificate, and someone who participated will get to take it home that night.

One more thing - every effort will be made to protect your confidentiality. As staff, we will not be in the room during the discussion, just the PSU researchers-and the PSU researchers will ask all participants to honor the "what is said in the room stays in the room" rule. The PSU researchers won't know your full name, just your first name. In their report, the PSU researchers will focus on what the group says as a whole. We're interested in what we can learn from the information that comes from the group as a whole, not what individuals say.

[Confirm interest and whether any kind of child care or language assistance is needed.]

Do you have any questions?

Okay, so we have you down for participating in the group discussion on [repeat date, time and location]. We'll give you a follow-up phone call a day or two before to remind you.

Thanks for helping out. 


\title{
Sample Letter for Recruiting Focus Group Members
}

\author{
[Housing Authority Letterhead]
}

Dear xx:

We are writing to invite you to participate in a group discussion about the experience of finding a new place to live. We are working with some researchers from Portland State University to study how people with housing vouchers look for and find their homes. So we are inviting people like you, who have moved in the last year, to participate. We want to learn from your experience and strengthen our services. Your participation is completely voluntary.

The group discussion will take place on [date] and [time] at [location] and last for approximately two hours. There will be about 6- 12 people participating in the discussion, and it will be led by Dr. Andrée Tremoulet from Portland State University. We will provide some sandwiches and beverages at the beginning of the meeting to help keep you going strong. As a way of saying thank you for your participation, at the end of the discussion there will be a drawing for a \$25 gift certificate.

As staff, we will not be in room during the discussion, just the PSU researchers - and the PSU researchers will ask all participants to honor the "what is said in the room stays in the room" rule. The PSU researchers won't know your full name, just your first name, and their report will focus on what the group said as a whole. If they do include information about particular experiences, they will change details to try to keep the identity of the people involved confidential. We're interested in what we can learn from the information that comes from the group as a whole, not what individuals say.

I will contact you in the next week to find out if you are interested and can attend. Whether or not you choose to participate is up to you, and your choice will not affect your benefits or status with us. We hope you will consider this opportunity to help us improve our services.

Sincerely,

[Housing authority staff person] 


\title{
APPENDIX B-4
}

\section{FOCUS GROUP GUIDE}

\author{
As they walk in: \\ - Welcome \\ - First name on name tag \\ - Help yourself to food \\ - Informed consent
}

\section{Opening}

Thank you for coming. I'm Andree Tremoulet, and I'm a researcher at PSU, and this is Ryan Dann, a graduate student in urban studies who is working with me on this project. Appreciate your taking time.

Before we get started, I wanted to tell you about this study, explain the consent form, and also get agreement on some ground rules.

The four housing authorities in our region are interested in exploring some tools that might provide people who have housing vouchers with some additional information about things to consider when they choose a place to live, so they can make the best possible choice, given all the challenges you face.

There are two parts to today's meeting-listening to your experiences with finding a place to live, and then testing out one of our potential tools and getting your feedback. We're interested in learning from you-what you've been through, what you think about the potential tool-so we can develop a better toolbox that really works for people.

When you came in, we gave you a form that says "Consent Form for Participants in Research Study." It explains that we will treat all information from today's meeting as being confidential. While we will write up a report, that report will not identify who participated or what specific individuals said. The PHAs won't be able to listen to the recording or read the notes we take. Is everyone okay with my recording this, so we don't have to take so many notes?

By signing this form, you are agreeing to participate in an audio-recorded focus group, with the understanding that you can withdraw at any time, if you want to. Does anyone have any questions about the form? Sign one and return it to us; keep one for yourself if you want. [Collect copies.]

Ground Rules

- What is said in the room, stays in the room

- Speak up when you have something to contribute. You don't have to wait for me to call on you.

- One person should speak at a time. No side conversations.

- Let others speak and listen to what they have to say without interrupting them. 
- Be courteous. Expressing disagreement is fine. Just disagree with what was said, and do not make your comments personal.

Let's get started.

Warm Up Questions

- One of the things that everyone here has in common is that you have moved in the last year or so. Could you introduce yourself by saying your first name, whether you like where you live now or where you used to live better, and what you like about the place you prefer?

How New Home Was Chosen

- We'd like you think back to when you moved to your current home. Please tell us the steps you went through to find it.

o How many places did you consider? Call? Visit? Apply to?

o Why did you choose the one that you did?

- What impacted your choice of where you moved to?

o Did you know someone else who lived there?

o Convenience of location/easy to get to the things you need to get to on a regular basis?

o Was it your first choice? [If not, what were you looking for? If it was, did it have what you were looking for?]

o Features of the unit

o Price

- When you were looking, were you primarily looking for a place in a particular area, or were you looking for a particular kind of unit in a lot of different neighborhoods?

o Before you contacted the housing authority about moving, did you already know the place you wanted to move? [Prompts-The exact housing complex, the general neighborhood, the part of the city?]

- People move for a lot of different reasons - sometimes by choice, and sometimes because they have to. It would help us put what we are hearing about your experiences in context if we knew why you moved. So, what put the wheels in motion on your move?

- What kinds of challenges did you experience in finding and securing a new place to live? How did you solve them?

Sources of Information/Factors Considered

This next group of questions has to do with the information you used in finding a place to move

- What sources of information did you turn to to find a place to live? [Follow upWhat were the best sources?]

- What kind of information did you receive from the housing authority? [Follow up--Did any of it help in finding a place to live?]

- I'd like you to consider if there was anything you wish you had known before you moved, but didn't. What was that? [Prompt-What advice would you give to someone who is looking for a new place to live?]

- When you chose where to live, how much did you consider the costs of getting around-transportation costs? How did it factor in to your decision-making? 


\section{Elicitation Questions}

- What are the plusses of considering transportation needs, costs and options when you choose a place to live?

- What things make it easy for you to factor in transportation needs, options and costs in choosing a place to live?

- What things make it hard for you to factor in transportation needs, options and costs in choosing a place to live?

- What kinds of things would help you overcome any barriers to factoring in transportation when choosing a place to live?

Formats for Information

We have been asked to come up with some tools to give people the information that they need to choose a good place to live. We understand that you do not have unlimited choices here, and that it costs money and time to submit applications for housing. We'd like to show you one of the tools (we're showing different ones to different groups) and get your feedback on what you like and don't like about them, and what you think is useful.

- What do you like? What don't you like?

- What is hard about using it? How can we make it easier to use?

- Would you use it? Why or why not?

- When is the best time to get information like this?

- What advice do you have for us about developing tools to help people consider their transportation needs and costs when they move?

Concluding Question

Anything else you would like to tell us about what you think might help people make good choices?

Drawing for gift certificate 


\title{
APPENDIX B-5
}

\section{APPROVED HUMAN SUBJECTS CONSENT FORM TEXT}

\author{
[Center for Urban Studies Letterhead] \\ Consent Form for Participation in Research Study \\ Mobility Information Program
}

You are invited to participate in a research study conducted by Dr. Andrée Tremoulet from Portland State University's Center for Urban Studies. We have been asked to study how people who have vouchers choose their housing. We have also been asked to develop some tools for Housing Authorities so that they can provide future voucher holders with good information about their housing and transportation options and trade-offs and to then evaluate the effectiveness of those tools.

We are inviting you to participate because you have a housing voucher and you have moved in the last year. We think you can help us understand the choices and pressures you experienced so that we can develop tools to help other voucher holders in the future.

If you decide to participate, you will be asked to take part in a 90-minute group discussion about what it was like to move and what kinds of assistance would have been helpful to have.

Your participation in this discussion will be treated as confidentially as possible by the researchers. Our report will focus on what we learned from the group as a whole. If we include information about particular experiences, we will change details to try to keep the identity of the people involved confidential. While we cannot guarantee confidentiality, we are asking all of the participants to follow the rule, "What is said in the room stays in the room." We have informed the Housing Authority that, should potential breaches in Housing Authority policies arise during the discussion, we, as researchers, will not share that information with them.

With your permission, we would like to audio-record the group discussion so that we don't have to take so many written notes. The only people who will listen to the recording or read the notes will be the researchers and our associates. No one from the Housing Authority will be allowed to listen to the recording or read the transcript. The recordings and transcripts will be stored in a secure place at PSU and be erased three years after the completion of the research.

The main risk in participating is the inconvenience associated with taking approximately two hours of your time to share information about your experience.

Your participation is voluntary. Your decision about participating will not affect your housing benefits (or any other benefits) or your relationship with the Housing Authority or with Portland 
State University. You may withdraw at any time. You may also skip responding to any of the questions that you do not want to answer.

As a way of thanking you for your time, we have provided food and beverages. At the end of the discussion, we will have a drawing among participants for a $\$ 25$ gift certificate. PSU requires that we remind the winner that he or she will be responsible for any taxes assessed on the gift certificate.

By participating, you will help us design a program that will help other people who have housing vouchers and who are looking for a place to live.

If you have any concerns about your participation or your rights as a research subject, please contact the Human Subjects Research Review Committee, Office of Research and Sponsored Projects, Portland State University, PO Box 751, 1600 SW Fourth Ave Suite 620, Portland, OR 97207, (503) 725-4288/1-877-480-4400. If you have questions about the study itself, contact Dr. Andree Tremoulet at 503 725-4075.

Your signature indicates that you have read and understood the information above and agree to participate in the study, and it does not waive any legal claims, rights or remedies. You may withdraw this consent at any time without penalty.

Thank you very much for taking the time to share your experiences with us. We value what you have to say.

Signature

Date 


\section{APPENDIX C-1 \\ TOOLBOX MESSAGING PAMPHLET}

\section{Resources}

Websites

Check out these websites to locate the best areas to look

for housing based on the places you go often: http://www.walkscore.com/apartments http://www.padmapper.com

This website can help you figure out travel distances, times and options (like the bus or walking)

$$
\text { http://www.maps.qooqle.com }
$$

Other Resources

Find links to:

Transportation Costs Video

Transportation \& Housing Check List

Transportation \& Housing Costs Worksheet

and other information at

http://www.vhausa.com/transportationcosts.html.

For More Information

Vancouver Housing Authority

2500 Main Street,

Vancouver, WA 98660

Phone: 360-694-2501

Email: mailto:miwichert@vhausa.com

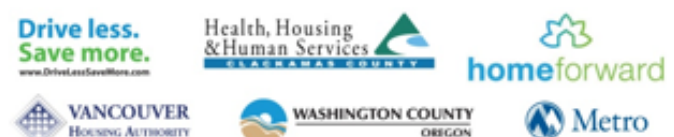

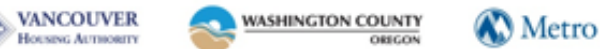

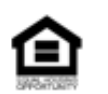

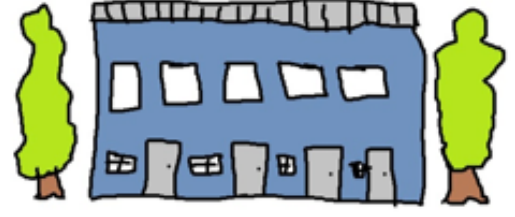

LOOKING FOR A PLACE TO LIVE?

\section{Think bigger than just the home}

When you choose a place to live, you're choosing more than a safe, affordable space for you and your family.

You're also choosing a neighborhood that meets your family's needs. You're choosing schools, stores, medical providers, job commutes and many other things that affect how much time and money you'll spend on transportation.

\section{Why consider transportation now?}

In our area, transportation costs about $30 \%$ of what families with housing assistance earn each month. For many, that's about as

much as your housing costs.

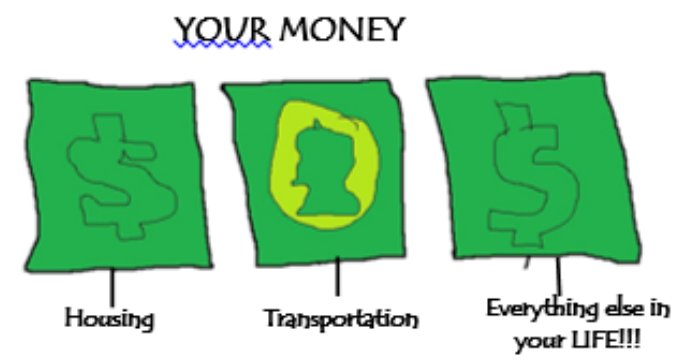




\section{Transportation costs sneak up on you}

Most people know how much they pay for rent because it's paid all at once. But most people don't realize how much they spend on transportation, as the costs are paid gradually. Think about it - gas, bus passes, car repairs, insurance - they all add up. And then there's the "time cost" of long commutes.

Let's take a look at an example of actual cost and time savings that can result from a smart move

\section{Meet Sally and her daughter}

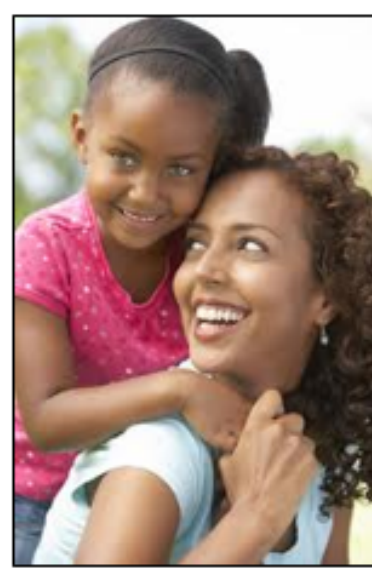

Sally took her current job because it was close to her sister, who looks after her daughter during the day. Unfortunately, her commute was miserable -60 miles per day - and expensive at $\$ 250$ per month. SQ Sally moved closer to work. Now she can walk to work and to her sister's house, which is great

because her car is starting to give her problems. And, with the money she's saving from not buying gas, she is thinking about going back to Clark College, which is right down the street.

Sally's monthly savings with this move: $\$ 170$ per month in driving costs 12 hours in travel time

*While the family in the example is not real, the housing and transportation options and costs are based on real information.

\section{What can you do?}

Look for an area that's affordable and provides easy access to important destinations for you.

Think of the places you often go. Then identify an area to look for housing where you could get to your regular destinations in a reasonable amount of time and at a reasonable cost. Start your search there.

Compare not just the places, but also the commutes Let's say you've found two places to live that fit your needs. Have you figured how much time and money you'd spend on transportation at each? It might help you decide which place is really best for you.

\section{Think about other ways to travel}

Consider whether transit, biking or walking, instead of driving, is reasonable. Using these options even a little bit can save you money. Plus walking or biking can improve your health and mood!

\section{Sure, you have challenges}

$>$ Finding housing you can afford

$>$ Finding a decent landlord

$>$ Having reasonable access to the places you need to go

Maybe getting past a poor rental or credit history

\section{But you also have choices}

Transportation time and costs matter. When you spend less on transportation, you'll have more time and money to spend on what your family needs to succeed.

\section{Consider your transportation options and costs before you make a move.}




\section{APPENDIX C-2 \\ INTRODUCTORY VIDEO}

Website for Video: http://youtu.be/C-eND_MgQPE

Length: 6 minutes 15 seconds

Language: English

\section{Text of video}

1. Are you thinking about moving?

2. Then this presentation is for you.

3. You probably already know that, when you choose a place to live, you are picking more than four walls and a roof over your head.

4. You know that you're also choosing

**Neighbors

** Your neighborhood,

$* *$ How safe you'll feel,

** Your grocery store,

**Which school your kids will go to,

**And how far it is to get to work.

5. You may know that choosing a home also means you're choosing

** how you get around,

**How long it takes you to get around,

**And even how much you'll spend on transportation.

**So, when you choose your home,

**you're also choosing how much time and money you'll spend

**to get to your regular destinations.

6. But here's something that most people don't know.

In our area, transportation costs most families who have housing assistance about $30 \%$ of what they earn each month. For many, that's about as much as housing.

7. You most likely know how much you pay for rent---you pay it all at once.

But you may not realize how much you spend on transportation, because you pay for it a little bit at a time. Think about it...

** gas,

**bus passes,

** car repairs,

**insurance...

$* *_{\text {it }}$ all adds up. 
8. So, think about what it might mean if you could choose housing that would enable you to reduce your transportation costs.

The more you can save on transportation,

**the more you can have to spend on other things that matter to you. Let's look at an example.

9. Meet Rachel and her family. While Rachel, Joelle and Davian aren't real people, all the information in this story is based on real places and facts. When Rachel's lease was getting ready to expire,

** she decided that she wanted to move.

**She wanted to find a place that was better for her two teenage kids.

**and was closer to her new job working for the county.

**Right now, she's spending about a half hour every day commuting.

10. She started by looking into the programs at high schools near where she worked. She figured out the neighborhoods she would need to live in, and then looked for places for rent online and by walking around during her lunch breaks. After a few weeks, she found a place, applied, and got in.

11. Now Joelle, who has a beautiful singing voice,

** will get to go to a school with a great choir,

**and Davian's school has a much better science program. He hopes to become a medic when he grows up.

Plus, Rachel is just eight minutes by car from where she works. So she can get to work in no time.

**Rachel's biggest bonus in this move? No more sitting in rush hour traffic.

12. Rachel's monthly savings with this move are

--\$80 per month in car expenses like gas

--5 hours saved in travel time

13. If, like Rachel, you're thinking about moving,

** we have some new tools that you can use.

14. If you have access to the internet through a computer-it can be at a library or even on a cell phone-you can go to websites that can help you figure out good areas to look for housing based on your frequent destinations.

15. One of the free, online tools you can use is Walkscore Apartment Finder. Here's how it works.

**First, you enter in the place you go most often-like work, or your doctor, or the store, or a relative's house.

**Then, you enter in the kind of transportation you plan to use to get there-car, transit, walking or biking-

**and how long you're willing to travel. 
Then, it will create a map like the one you see here.

**The highlighted area is your "travel zone"---

the parts of your community that are within your chosen travel time of your destination.

That's where you want to look first for housing.

16. You can even enter in two or more destinations, like this example here, and the program will create travel zones for each.

**The best place to look for housing is where the two travel zones overlap.

17. One way to use your map is to print a copy and then walk or ride around your travel zone and look for places with for-rent signs.

18. You can look housing in your travel zone on that same website-they have links to some rental listings.

**You can search the listings for places with the right number of bedrooms and rent in a range that you can afford.

There's no guarantee you'll find anything, but it's easy to check.

Remember---these websites don't show everything that's for rent, and it may be hard to meet some of the screening criteria. You still have to do your homework and make the calls.

19. Here are two websites that can help you figure out your commuting zones and look for listings:

**Apartment Finder by Walkscore

**Padmapper

A third website,

**Google Maps, can help you figure out how long it will take you to get to places you go frequently.

**You can check out these websites anytime you want-they're free.

We can show you how to get more information about how to use them.

20. We also have two other tools to help you make smart choices about transportation when you are looking for a place to live. You don't need a computer for either of these.

**The first is a worksheet that will allow you to compare transportation costs for two places you're thinking of living.

**The second is a checklist you can use when you go onsite to look at a place to rent. Ask us how to get these tools.

21. Okay, we've done a lot of talking. And if you're moving, you may feel like you're under a lot of pressure. But just remember this-

$* *$ While you may have may challenges,

** you also have choices.

22. Be smart. Consider your transportation options and costs before you make a move. 


\section{APPENDIX C-3 WALKSCORE GUIDE Walk Score Apartment Finder}

http://www.walkscore.com/apartments

Current as of March 2014

Search for apartments by

commute time, near public transit, and near places like grocery stores, schools, and hospitals.

Customize your search: price, beds, neighborhood, etc.

Search by how you travel: car, bus, bike, or walk.

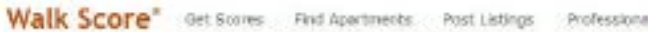

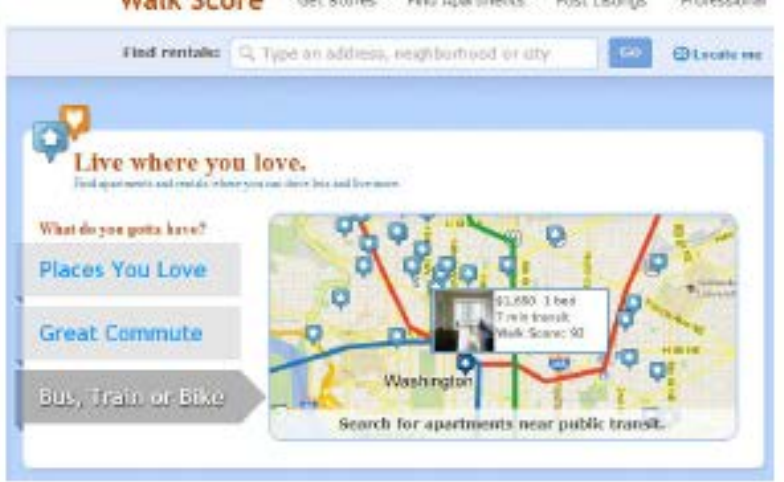

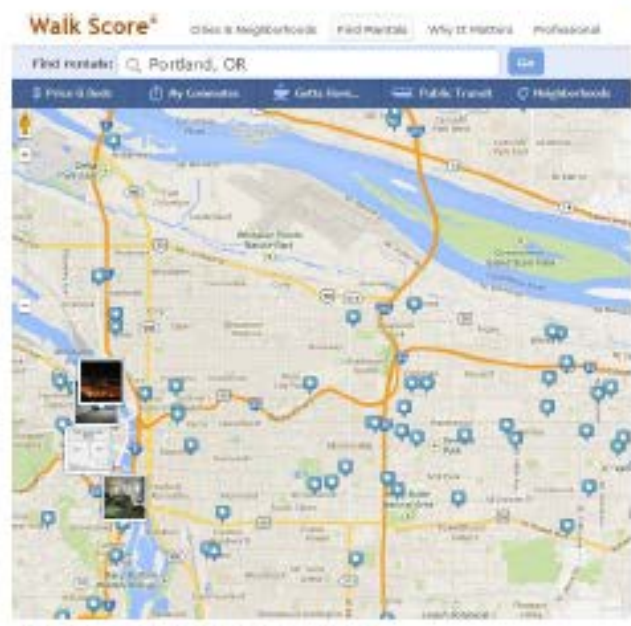

Search for what's nearby.

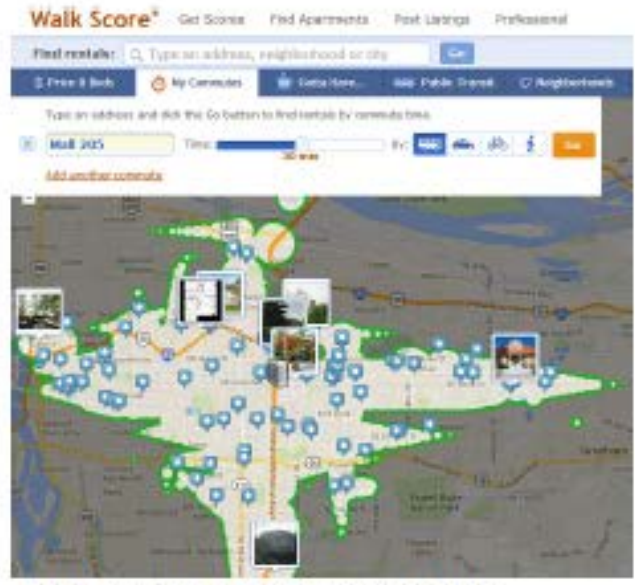

Find apartments by commute time.

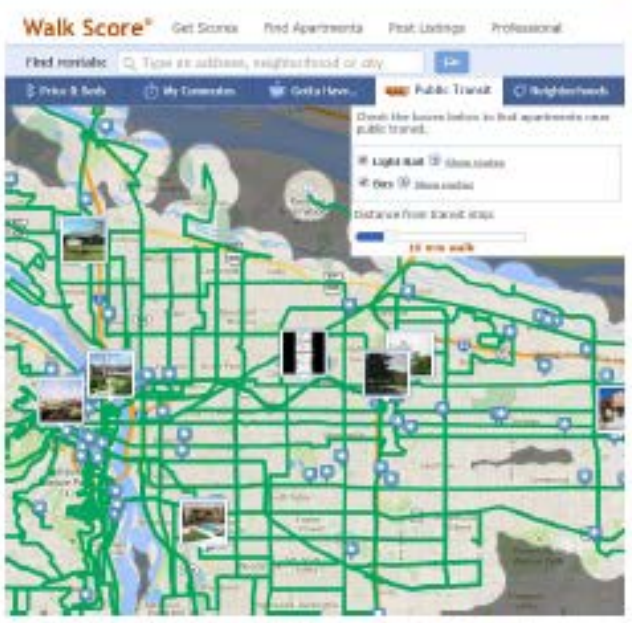

Browse apartments near transit lines.

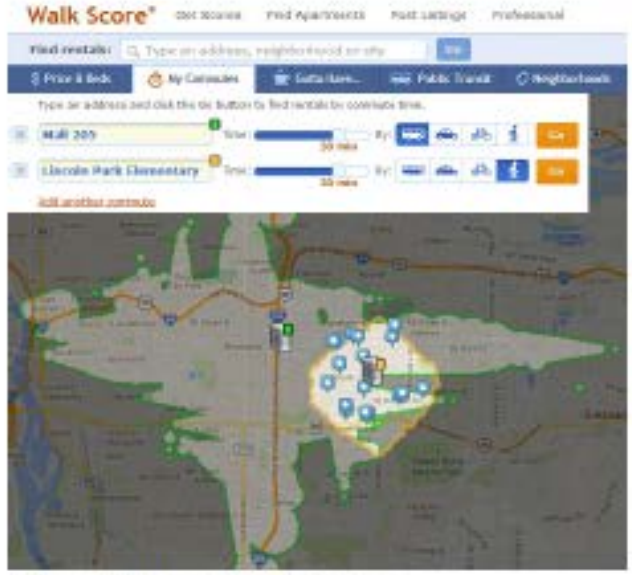

Or multiple commute times. 


\section{Getting started using Walk Score Apartment Finder}

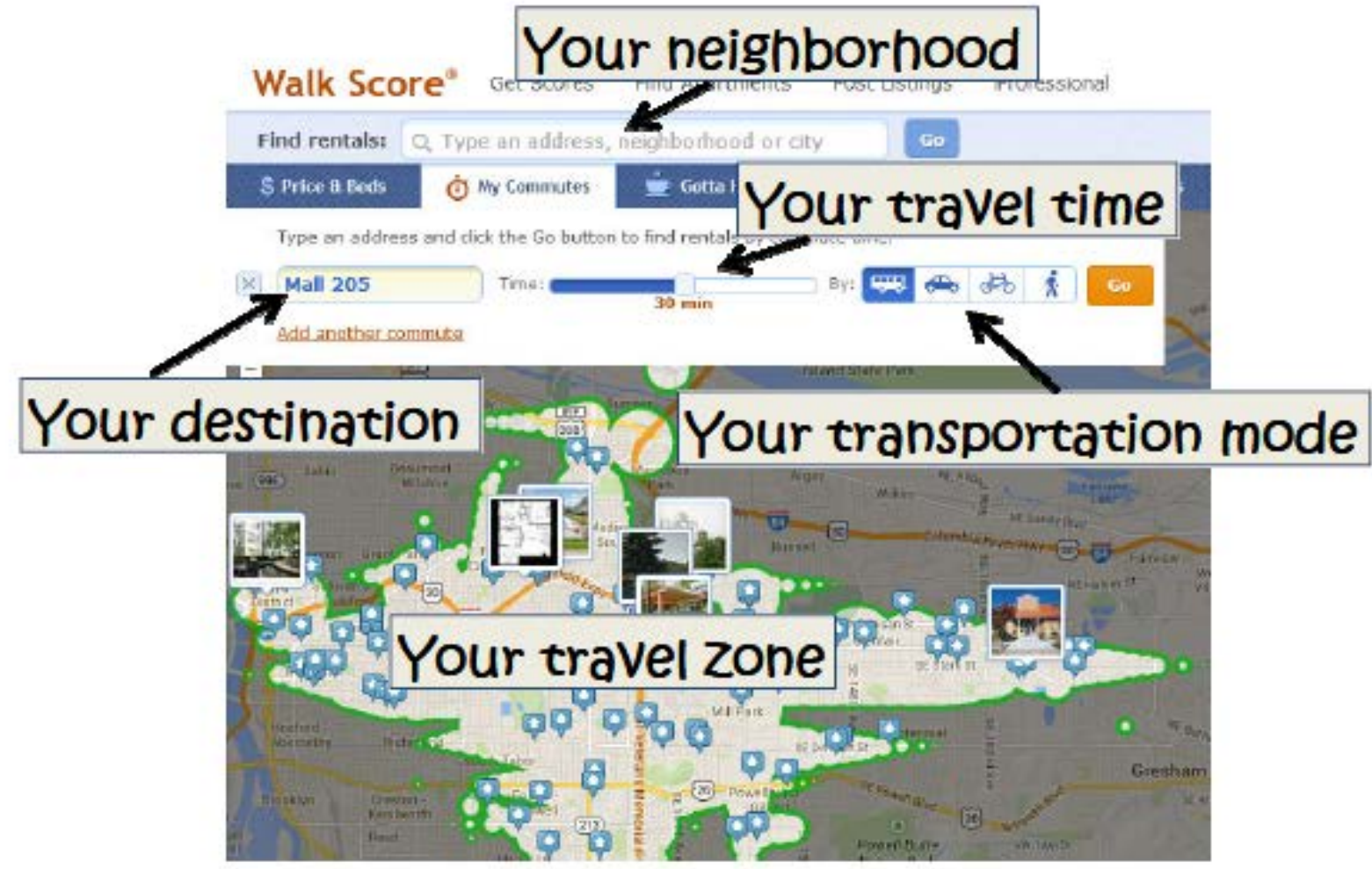

Save your search

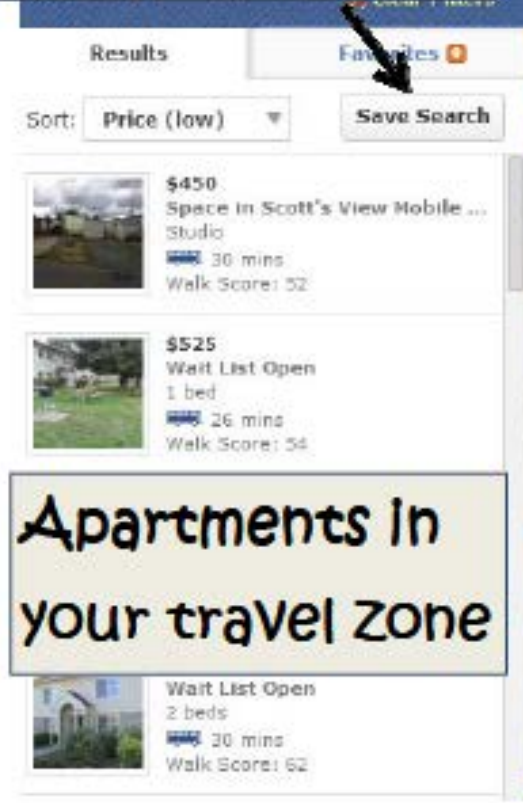

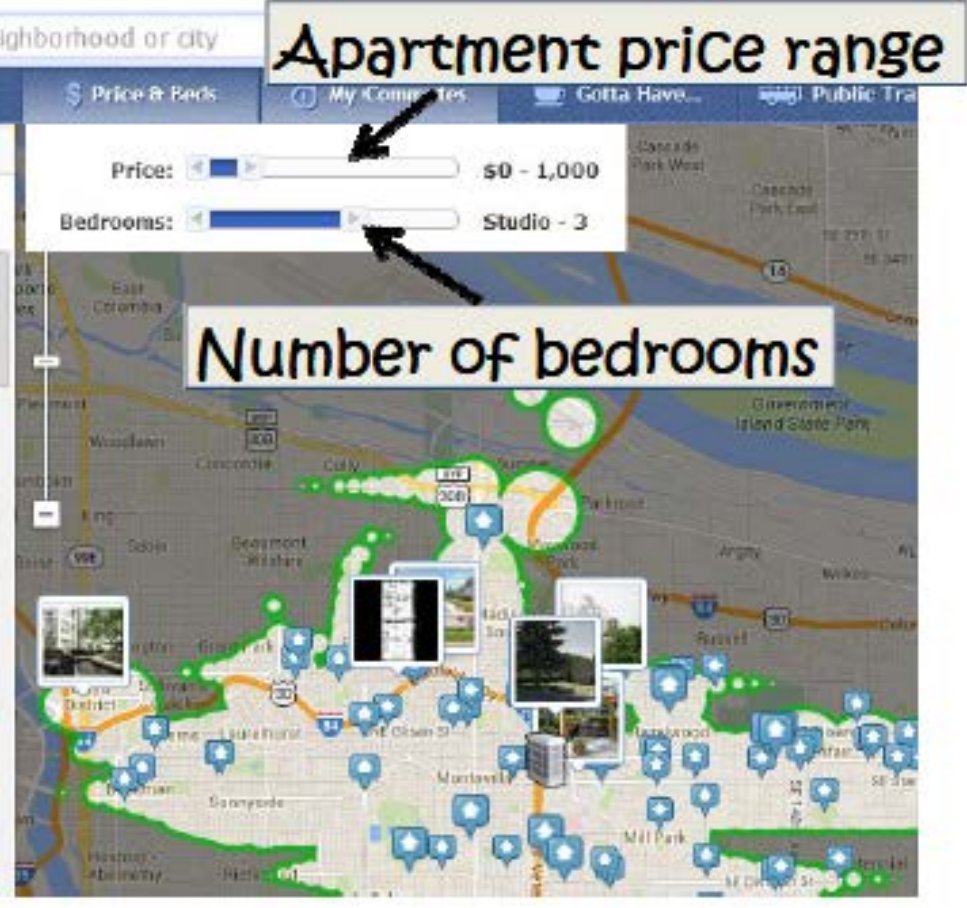




\section{APPENDIX C-4 \\ HOUSE FINDING CHECKLIST}

\section{For More Information}

Find Links To:

Transportation Costs Video

Transportation \& Housing Check List

Transportation \& Housing Costs Worksheet

and other information at

http://www.vhausa.com/transportationcosts.html.

For More Information

Vancouver Housing Authority

2500 Main Street,

Vancouver, WA 98660

Phone: 360-694-2501

Email: mailto:miwichert@vhausa.com

Websites

Check out these websites to locate the best areas to look

for housing based on the places you go often:

http://www.walkscore.com/apartments

http://www.padmapper.com

This website can help you figure out travel distances, times

and options (like the bus or walking)

http://www.maps.qoogle.com

\section{Health, Housing}

Drive less.
Save molth, Housing
\&xHuman Services

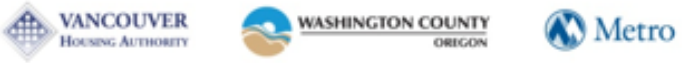

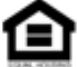

CHECK IT OUT!

Make Sure the Home

Is Right for You

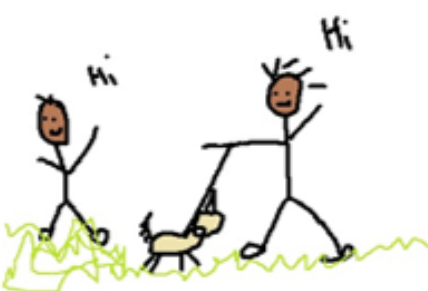




\section{Housing Conditions: The Basics}

$\triangle$ Is the property well-maintained overall?

$\triangle$ Does the entry to the unit feel safe? Would you feel comfortable going in and out at night?

$\Delta$ Is the apartment clean? Does the apartment smell clean? (If there's a funny odor, ask what it is and what they will do about it.)

$\triangle$ Does the plumbing work? Turn the faucets on and off, flush the toilet.

$\triangle$ Do the kitchen appliances (refrigerator and stove) work?

$\triangle$ Do you think the apartment will pass the Housing Quality Standards (HQS) inspection by the Housing Authority?

$\checkmark$ Will you have access to a washer and dryer in the complex?

- If you have a car, is there a convenient and safe place for you to park?

$\checkmark$ If you have children, is there a place for them to play?

$\checkmark$ How quiet or noisy is the apartment complex? Does that fit with your lifestyle?

$\triangle$ Does the neighborhood feel safe? Try to check it out at different times of day-morning, afternoon and nighttime.

$\checkmark$ Try to find a home you want to live in for years. Do you like it? Do you feel comfortable there?

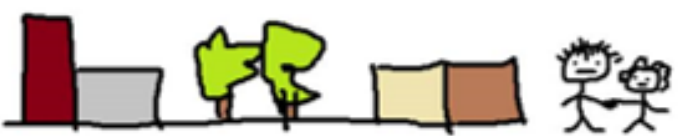

\section{When You Meet Your Landlord}

- First impressions count. Dress accordingly.

$\triangle$ Bring your references, photo ID and application fee.

$\triangle$ If the landlord accepts you as a tenant, bring your Housing Authority forms.

\section{Costs: Get the Full Picture Up Front}

$\triangle$ Do you think you will pass the screening criteria? Ask for a copy of the landlord's screening criteria before you submit an application and pay an application fee. If you don't think you'll pass, think twice about spending the money to apply.

- How much is the application fee? Is it refundable? Can it be applied to the first month's rent?

With your Section 8 voucher, how much will you have to pay in rent each month?

What utilities are NOT included in the rent? How much do they cost, on average, each month?

Do you have to pay extra for pets (if you have them), parking, laundry or other things?

$\checkmark$ How much is the security deposit? What is the policy about getting it back when you move?

$\triangle$ Which utilities do you have to set up yourself? Do they require deposits?

\section{The Hidden Cost: Transportation}

- How will you get to the places you need to go on a regular basis? (Work, school, friends).

$\checkmark$ Where's the nearest grocery store? How will you get there and back with groceries?

If you drive, will you likely spend more on gas than you do now if you move here? A lot more?

$\checkmark$ Is there a transit stop near you? How often does the bus or train come? Does it go directly to places where you need to go, or will you have to transfer?

- Can you walk (or go in your wheelchair) to run errands from here?

If you have kids, how will they get around if you live here? Are there safe places for them to go? 


\section{APPENDIX C-5 \\ TRANSPORTATION AND HOUSING COST COMPARISON WORKSHEET}

Transportation + Housing Cost Comparison Worksheet

Here's an example

\begin{tabular}{|c|c|c|c|}
\hline \multicolumn{4}{|c|}{ Home 1 Address: 98765 Marshmallow Drive } \\
\hline $\begin{array}{l}\text { 1. Name } 3 \text { places you go } \\
\text { often. }\end{array}$ & work & $\begin{array}{l}\text { Sister's } \\
\text { house }\end{array}$ & grocery \\
\hline $\begin{array}{l}\text { 2. How will you get there? } \\
\text { (Bus, walk, drive, etc.) }\end{array}$ & car & car & car \\
\hline $\begin{array}{l}\text { Number of times per } \\
\text { week you go to each }\end{array}$ & 5 & 4 & 3 \\
\hline $\begin{array}{l}\text { 4. Miles from your home } \\
\text { woww maps,geggle.com }\end{array}$ & 4.2 & 18.3 & 1.5 \\
\hline $\begin{array}{l}\text { 5. Round trip miles per } \\
\text { month }=8 \times(\# 3 \times \# 4)\end{array}$ & 168 & 585.6 & 36 \\
\hline $\begin{array}{ll}\text { 6. } & \text { Cost per } \text { month } \\
\text { - } & \text { Car }=30 \text { cents } / \text { mile }(.3) \\
\text { - } & \text { Bus }=\text { Transit fares } \\
\text { - } & \text { Walk }=\text { No cost }\end{array}$ & $\$ 50.40$ & $\$ 175.68$ & $\$ 10.80$ \\
\hline \multicolumn{3}{|c|}{$\begin{array}{l}\text { YOUR TRANSPORTATION COST EACH MONTH } \\
\text { Add the three columns }\end{array}$} & $\$ 236.88$ \\
\hline
\end{tabular}

\begin{tabular}{|c|c|c|c|}
\hline \multicolumn{4}{|c|}{ Home 2 Address: 1234 Main Street } \\
\hline $\begin{array}{l}\text { 1. Name } 3 \text { places you go } \\
\text { often. }\end{array}$ & work & $\begin{array}{l}\text { Sister's } \\
\text { house }\end{array}$ & grocery \\
\hline $\begin{array}{l}\text { 2. How will you get there? } \\
\text { (Bus, walk, drive, etc.) }\end{array}$ & bus & walk & walk \\
\hline $\begin{array}{l}\text { 3. Number of times per } \\
\text { week you go to each }\end{array}$ & 5 & 4 & 3 \\
\hline $\begin{array}{l}\text { 4. Miles from your home } \\
\text { wawe mans,goggle.coman }\end{array}$ & 6.8 & .2 & .1 \\
\hline $\begin{array}{l}\text { 5. Round trip miles per } \\
\text { month }=8 \times(\# 3 \times \# 4)\end{array}$ & 272 & 6.4 & 2.4 \\
\hline $\begin{array}{l}\text { 6. Cost per month } \\
\text { - Car }=30 \text { cents/mile (.3) } \\
\text { - } \text { Bus }=\text { Transit fares } \\
\text { - } \text { Walk = No cost }\end{array}$ & $\begin{array}{l}\$ 100 \\
\text { monthly } \\
\text { bus pass }\end{array}$ & $O$ & $O$ \\
\hline \multicolumn{3}{|c|}{$\begin{array}{l}\text { YOUR TRANSPORTATION COST EACH MONTH } \\
\text { Add the three columns }\end{array}$} & $\$ 100$ \\
\hline
\end{tabular}

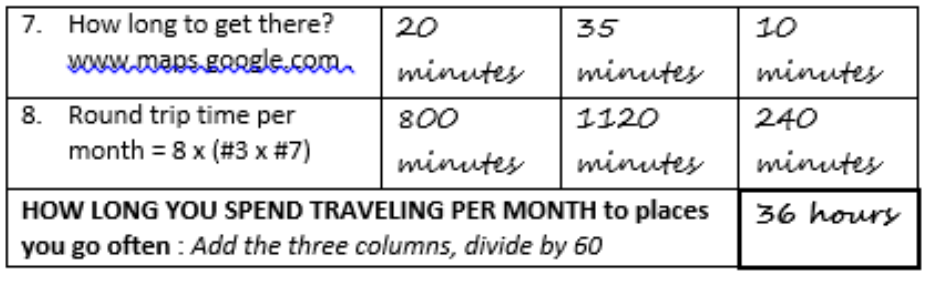

\begin{tabular}{|c|c|c|c|}
\hline $\begin{array}{l}\text { 7. How long to get there? } \\
\text { wowu moaps.goggle.comen }\end{array}$ & $\begin{array}{l}48 \\
\text { minutes }\end{array}$ & $\begin{array}{l}10 \\
\text { minutes }\end{array}$ & 5 \\
\hline $\begin{array}{l}\text { 8. Round trip time per } \\
\text { month }=8 \times(\# 3 \times \# 7)\end{array}$ & $\begin{array}{l}1920 \\
\text { minutes }\end{array}$ & $\begin{array}{l}320 \\
\text { minutes }\end{array}$ & $\begin{array}{l}120 \\
\text { minutes }\end{array}$ \\
\hline \multicolumn{3}{|c|}{$\begin{array}{l}\text { HOW LONG YOU SPEND TRAVELING PER MONTH to places } \\
\text { you go often : Add the three columns, divide by } 60\end{array}$} & $\begin{array}{l}39.3 \\
\text { houry. }\end{array}$ \\
\hline
\end{tabular}

Compare your combined monthly housing and transportation costs and see how much of your income is left.

\begin{tabular}{|l|l|l|l|l|l|}
\hline & Your Income & $\begin{array}{c}\text { Your Housing Cost } \\
\text { from Section 8 estimate }\end{array}$ & $\begin{array}{c}\text { Your Transportation Cost } \\
\text { from above }\end{array}$ & $\begin{array}{c}\text { Your Housing + } \\
\text { Transportation Costs }\end{array}$ & What's Left \\
\hline Home 1 & $\$ 450$ & $\$ 150$ & $\$ 237$ & $\$ 387$ & $\$ 63$ \\
\hline Home 2 & $\$ 450$ & $\$ 150$ & $\$ 100$ & $\$ 250$ & $\$ 200$ \\
\hline
\end{tabular}




\section{Transportation + Housing Cost Comparison Worksheet}

Complete this worksheet to compare your combined housing and transportation costs to places you go often for two housing options What You Need: Section 8 Assistance estimate, calculator, access, to Internet via computer or cell phone

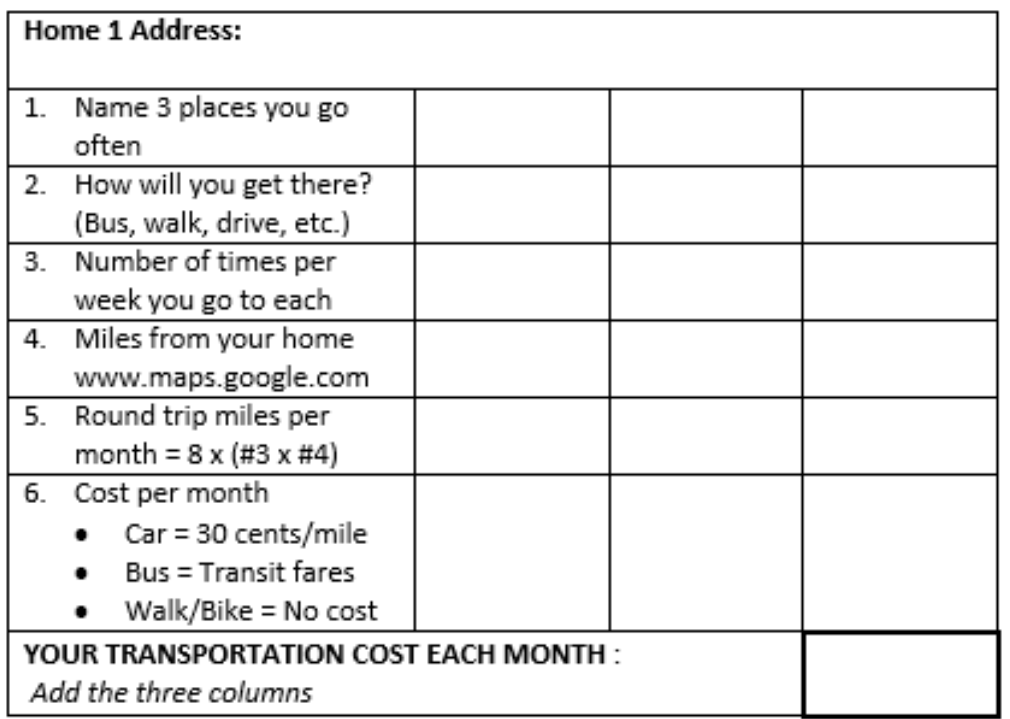

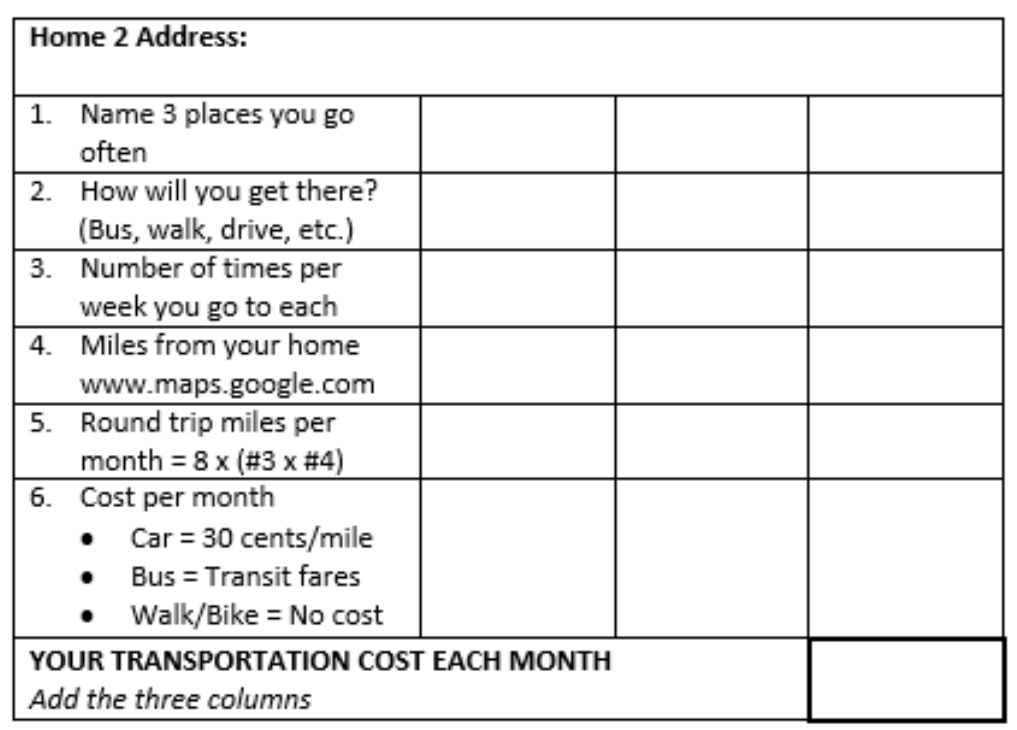

\begin{tabular}{|ll|l|l|l|}
\hline $\begin{array}{l}\text { 7. } \\
\text { How long to get there? } \\
\text { www.maps.google.com }\end{array}$ & & & \\
\hline $\begin{array}{l}\text { 8. } \\
\text { Round trip time per } \\
\text { month }=8 \times(\# 3 \times \# 7)\end{array}$ & & & \\
\hline $\begin{array}{l}\text { HOW LONG YOU SPEND TRAVELING PER MONTH to places } \\
\text { you go often : Add the three columns }\end{array}$ & \\
\hline
\end{tabular}

\begin{tabular}{|l|l|l|l|}
\hline $\begin{array}{l}\text { 7. } \\
\text { How long to get there? } \\
\text { www.maps.google.com }\end{array}$ & & & \\
\hline $\begin{array}{l}\text { 8. } \\
\text { Round trip time per } \\
\text { month }=8 \times(\# 3 \times \# 7)\end{array}$ & & & \\
\hline $\begin{array}{l}\text { HOW LONG YOU SPEND TRAVELING PER MONTH to places } \\
\text { you go often : Add the three columns }\end{array}$ & \\
\hline
\end{tabular}

Compare your combined monthly housing +transportation costs and see how much of your income is left.

\begin{tabular}{|l|l|c|c|c|c|}
\hline & Your Income & $\begin{array}{c}\text { Your Housing Cost } \\
\text { from Section 8 estimate }\end{array}$ & $\begin{array}{c}\text { Your Transportation Cost } \\
\text { from above }\end{array}$ & $\begin{array}{c}\text { Your Housing + } \\
\text { Transportation Costs }\end{array}$ & What's Left \\
\hline Home 1 & & & & & \\
\hline Home 2 & & & & & \\
\hline
\end{tabular}

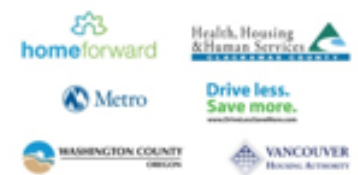




\section{APPENDIX C-6 PHA WEBSITE INTRODUCTORY TEXT}

\section{Mobility Toolkit}

Looking for a place to live?

You're choosing more than a home. You're also choosing:

- Neighbors

- Schools, stores and a neighborhood

- How much time and money you spend on transportation

Make the most of this opportunity. Watch this short video:

Xxxxxxx Linkxxxxx

Your Mobility Toolkit

- Mobility Brochure (pdf)

- $\quad$ Check It Out (pdf)

- Transportation Cost Worksheet (pdf)

- Using Walkscore Apartment Finder (pdf)

Primary Mobility Resources

- Walk Score Apartment Finder: http://www.walkscore.com/apartments/

- Padmapper: http://www.padmapper.com/

- Google Maps: http://maps.google.com/

Additional Links

- GoSection8: http://www.gosection8.com/

- PHA's listing

Remember, you may have challenges, but you also have choices. Consider your transportation options and costs before you move. 


\section{APPENDIX D-1 CONTROL GROUP PRE-MOVE SURVEY}

Mousing
Choies
Vougher
Mover
Sunvey
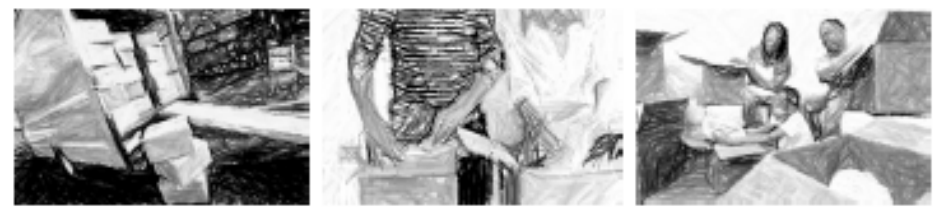

P Portland State

1. Thinking about your current home and neighborhood, to what extent do you agree with each statement?

\begin{tabular}{|c|c|c|c|c|}
\hline & $\begin{array}{l}\text { Strongly } \\
\text { agree }\end{array}$ & Agree & Disagree & $\begin{array}{l}\text { Strongly } \\
\text { Disagree }\end{array}$ \\
\hline $\begin{array}{l}\text { There are many places I go within easy walking distance } \\
\text { of my home. }\end{array}$ & $\square_{1}$ & $\square_{2}$ & $\square_{3}$ & $\square_{4}$ \\
\hline $\begin{array}{l}\text { It is easy to walk to a bus stop or light rail station from } \\
\text { my home. }\end{array}$ & $\square_{1}$ & $\square_{2}$ & $\square_{3}$ & $\square_{4}$ \\
\hline My neighborhood is a good place for walking. & $\square_{1}$ & $\square_{2}$ & $\square_{3}$ & $\square_{4}$ \\
\hline
\end{tabular}

2. How would you most likely get to each of the following places from your current home? Please check just one for each place.

\begin{tabular}{|c|c|c|c|c|c|}
\hline & Walk & $\begin{array}{l}\text { Public } \\
\text { Transportation }\end{array}$ & Car & Bicycle & $\begin{array}{l}\text { Don't go } \\
\text { there }\end{array}$ \\
\hline A grocery store & $\square_{1}$ & $\square_{2}$ & $\square_{3}$ & $\square_{4}$ & $\square_{\mathrm{N} / \mathrm{A}}$ \\
\hline Doctor or dentist & $\square_{1}$ & $\square_{2}$ & $\square_{3}$ & $\square_{4}$ & $\square_{\text {NIA }}$ \\
\hline Home of friend or relative I often visit & $\square_{1}$ & $\square_{2}$ & $\square_{3}$ & $\square_{4}$ & $\square_{\text {NAA }}$ \\
\hline Store or shop (non-grocery) & $\square_{1}$ & $\square_{2}$ & $\square_{3}$ & $\square_{4}$ & $\square_{\mathrm{N} / \mathrm{A}}$ \\
\hline Children's school or childcare & $\square_{1}$ & $\square_{2}$ & $\square_{3}$ & $\square_{4}$ & $\square_{\text {NIA }}$ \\
\hline Church or place of worship & $\square_{1}$ & $\square_{2}$ & $\square_{3}$ & $\square_{4}$ & $\square_{\mathrm{N} A}$ \\
\hline $\begin{array}{l}\text { Agency I need to visit (such as Social } \\
\text { Security or Housing Authority) }\end{array}$ & $\square_{1}$ & $\square_{2}$ & $\square_{3}$ & $\square_{4}$ & $\square_{\mathrm{N} / \mathrm{A}}$ \\
\hline My place of work & $\square_{1}$ & $\square_{2}$ & $\square_{3}$ & $\square_{4}$ & $\square_{\mathrm{N} / A}$ \\
\hline Post office & $\square_{1}$ & $\square_{2}$ & $\square_{3}$ & $\square_{4}$ & $\square_{\mathrm{N} A}$ \\
\hline Restaurant, café or bar & $\square_{1}$ & $\square_{2}$ & $\square_{3}$ & $\square_{4}$ & $\square_{\mathrm{NA}}$ \\
\hline A park & $\square_{1}$ & $\square_{2}$ & $\square_{3}$ & $\square_{4}$ & $\square_{\mathrm{N} \text { A }}$ \\
\hline Other: & $\square_{1}$ & $\square_{2}$ & $\square_{3}$ & $\square_{4}$ & $\square_{\text {NIA }}$ \\
\hline
\end{tabular}

3. In the last week, how much of your daily travel was by each of the following? Do not include trips to work.

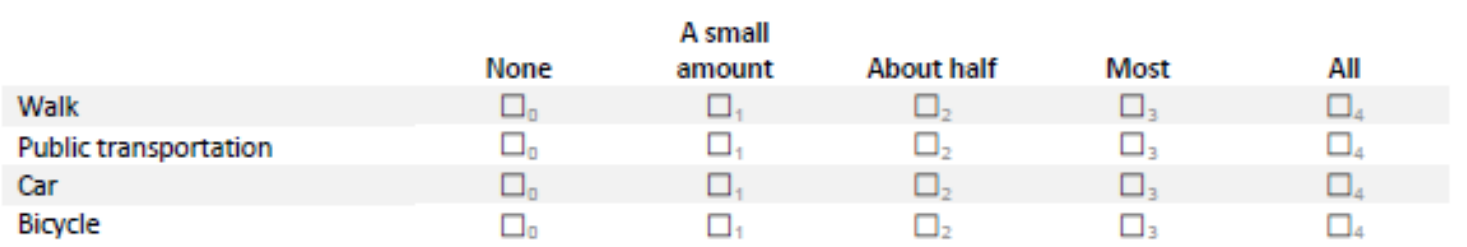

4. When you think about your new home, how much do you intend to walk, drive, use transit and bike for transportation purposes compared to your current home? Do not include trips to work.

\begin{tabular}{|c|c|c|c|c|c|c|}
\hline & Decrease a lot & $\begin{array}{c}\text { Decrease a } \\
\text { little }\end{array}$ & Stay the same & $\begin{array}{l}\text { Increase a } \\
\text { little }\end{array}$ & Increase a lot & Don't use it \\
\hline Walking & $\square_{0}$ & $\square_{1}$ & $\square_{2}$ & $\square_{3}$ & $\square_{4}$ & $\square_{\mathrm{N} / \mathrm{A}}$ \\
\hline Transit & $\square_{0}$ & $\square_{1}$ & $\square_{2}$ & $\square_{3}$ & $\square_{4}$ & $\square_{\text {N/A }}$ \\
\hline Driving & $\square_{0}$ & $\square_{1}$ & $\square_{2}$ & $\square_{3}$ & $\square_{4}$ & $\square_{\mathrm{N} / \mathrm{A}}$ \\
\hline Bicycling & $\square_{0}$ & $\square_{1}$ & $\square_{2}$ & $\square_{3}$ & $\square_{4}$ & $\square_{\mathrm{N} / \mathrm{A}}$ \\
\hline
\end{tabular}


5. How important are each of the following to you in choosing your new home?

$\begin{array}{lcccc}\text { Pot at all } & \begin{array}{c}\text { Moderately } \\ \text { important }\end{array} & \begin{array}{c}\text { Very } \\ \text { important }\end{array} & \begin{array}{c}\text { Extremely } \\ \text { important }\end{array} \\ \text { Property and unit well-maintained } & \square_{1} & \square_{2} & \square_{3} & \square_{4} \\ \text { Helpful property manager } & \square_{1} & \square_{2} & \square_{3} & \square_{4} \\ \text { Good public transportation } & \square_{1} & \square_{2} & \square_{3} & \square_{4} \\ \text { Private yard } & \square_{1} & \square_{2} & \square_{3} & \square_{4} \\ \text { Shopping areas within walking distance } & \square_{1} & \square_{2} & \square_{3} & \square_{4} \\ \text { Good schools } & \square_{1} & \square_{2} & \square_{3} & \square_{4} \\ \text { Low transportation costs } & \square_{1} & \square_{2} & \square_{3} & \square_{4} \\ \text { Neighborhood feels safe } & \square_{1} & \square_{2} & \square_{3} & \square_{4} \\ \text { A place where I fit in } & \square_{1} & \square_{2} & \square_{3} & \square_{4} \\ \text { Sidewalks throughout the neighborhood } & \square_{1} & \square_{2} & \square_{3} & \square_{4} \\ \text { I know the area } & \square_{1} & \square_{2} & \square_{3} & \square_{4} \\ \text { Access to bike routes } & \square_{1} & \square_{2} & \square_{3} & \square_{4} \\ \text { Parks and open space nearby } & \square_{1} & \square_{2} & \square_{3} & \square_{4} \\ \text { Near family or friends } & \square_{1} & \square_{2} & \square_{3} & \square_{4} \\ \text { Places to eat in walking distance } & \square_{1} & \square_{2} & \square_{3} & \square_{4} \\ \text { Children's play areas } & \square_{1} & \square_{2} & \square_{3} & \square_{4} \\ \text { Easy access to a freeway } & \square_{1} & \square_{2} & \square_{3} & \square_{4} \\ \text { Biggest unit for the money } & \square_{1} & \square_{2} & \square_{3} & \square_{4} \\ \text { Walking distance to schools } & \square_{1} & \square_{2} & \square_{3} & \square_{4} \\ \text { Cheaper rent and utilities } & \square_{1} & \square_{2} & \square_{3} & \square_{4} \\ \text { Easy access to medical and social services } & \square_{1} & \square_{2} & \square_{3} & \square_{4} \\ \text { Other } & \square_{1} & \square_{2} & \square_{3} & \square_{4}\end{array}$

6. How much do you agree or disagree with the following statements?

\begin{tabular}{|c|c|c|c|c|}
\hline & $\begin{array}{l}\text { Strongly } \\
\text { agree }\end{array}$ & Agree & Disagree & $\begin{array}{l}\text { Strongly } \\
\text { Disagree }\end{array}$ \\
\hline $\begin{array}{l}\text { If I wanted to, I could find a home within walking distance of } \\
\text { many places I need to go regularly. }\end{array}$ & $\square_{1}$ & $\square_{2}$ & $\square_{3}$ & $\square_{4}$ \\
\hline $\begin{array}{l}\text { If I wanted to, I could find a home where I would pay less for } \\
\text { transportation. }\end{array}$ & $\square_{1}$ & $\square_{2}$ & $\square_{3}$ & $\square_{4}$ \\
\hline $\begin{array}{l}\text { If I wanted to, I could find a home with good public } \\
\text { transportation that goes to the places I need to go. }\end{array}$ & $\square_{1}$ & $\square_{2}$ & $\square_{3}$ & $\square_{4}$ \\
\hline
\end{tabular}

7. How certain are you of where you want to live when you move?

I know which apartment or home I plan to move to.

$\begin{array}{crrc}\text { Strongly } & \text { Agree } & \text { Disagree } & \begin{array}{c}\text { Strongly } \\ \text { Dicapree }\end{array} \\ \square_{1} & \square_{2} & \square_{3} & \square_{4}\end{array}$

8. Why are you moving?

$\square_{1}$ My landlord gave me a notice or did not renew my lease, so I have to move.

$\square_{2}$ I am moving by my own choice; my landlord did not force me to move. 
9. How much do you agree or disagree with the following statements?

Walking can sometimes be easier for me than driving.

Strongly agree

$\square_{1}$

Agree

Disagree

Strongly

Traveling by car is safer overall than walking.

I prefer to walk rather than drive whenever possible.

I like walking.

It would be nice to live in a place where I could get by without a car for many of my needs.

I like riding a bike.

I like driving a car.

Traveling by car is safer overall than riding a bike.

Taking transit can sometimes be easier for me than driving.

I prefer to take transit rather than drive whenever possible.

I like taking public transportation.

Traveling by car is safer overall than taking public transportation.

I need a car to do many of the things I need to do.

Biking can sometimes be easier for me than driving.

10. How much do you agree or disagree with the following statements?

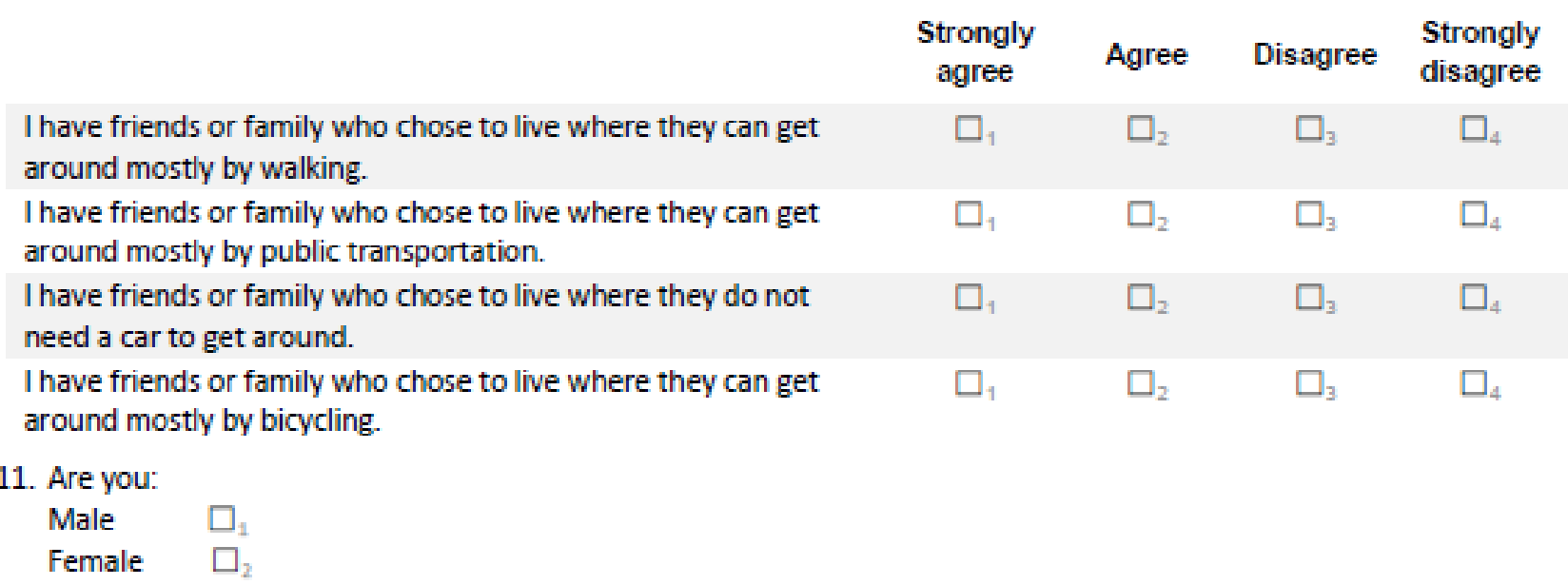

12. In what year were you born?

13. Do you currently have a valid driver's license?

$\begin{array}{ll}\text { Yes } & \square_{1} \\ \text { No } & \square_{0}\end{array}$

14. Do you have access to a car on most days?

$\begin{array}{ll}\text { Yes } & \square_{1} \\ \text { No } & \square_{1}\end{array}$

15. Do you have access to a bicycle on most days?

Yes $\square_{1}$

No 
16. Please write the number of people in your households that fall into each age category below. If none in that category, write zero (0).

\begin{tabular}{|l|l|l|l|l|}
\hline Newborn through 5 & 6 through 15 & 16 through 18 & 19 through 61 & 62 and older \\
\hline & & & & \\
\hline
\end{tabular}

17. Do you consider yourself either Hispanic or Latino/a?

$$
\square_{0} \text { No, not Hispanic or Latino }
$$

$\square_{1}$ Yes, Hispanic or Latino

18. Do you consider yourself:
$\square$. White or Caucasian
$\square_{2}$ Black or African American
$\square_{3}$ American Indian or Alaska Native
$\square_{4}$ Asian
$\square_{5}$ Native Hawaiian or Other Pacific
$\square_{6}$ Multiracial
$\square_{7}$ Other (please specify):

19. Are you currently employed in a job outside your home?
$\square_{1}$ Yes, full-time
$\square_{2}$ Yes, part-time
$\square_{0}$ No

20. What is your annual household income? (Please check just one box.)
$\square$ Less than $\$ 10,000$
$\square_{2} \quad \$ 10,000$ to $\$ 14,999$
$\square_{3} \quad \$ 15,000$ to $\$ 24,999$
$\square_{4} \quad \$ 25,000$ to $\$ 34,999$
$\square_{5} \quad \$ 35,000$ to $\$ 49,999$
$\square_{5} \quad$ More than $\$ 50,000$

21. Which one of the following four statements best describes your ability to get by on your income?
$\square$. I/we can't make ends meet
$\square_{2} \quad$ I/we have just enough, no more
$\square_{3} \quad \mathrm{l} /$ we have enough with a little extra sometimes
$\square_{4} \quad \mathrm{I} /$ we always have money left over

22. Do you have a physical limitation that prevents you from walking for more than a few blocks?
$\square$ Yes
$\square$ ○ No

23. Can you comfortably ride a bicycle?
$\square$ Yes
$\square$ No

24. Do you use a wheel chair or scooter regularly?
$\square$ Yes
$\square_{0}$ No

25 . What year did you move into your current home?

THANK YOU! Please return this survey to your Housing Authority staff person in envelope provided. S1 11/03/2013 


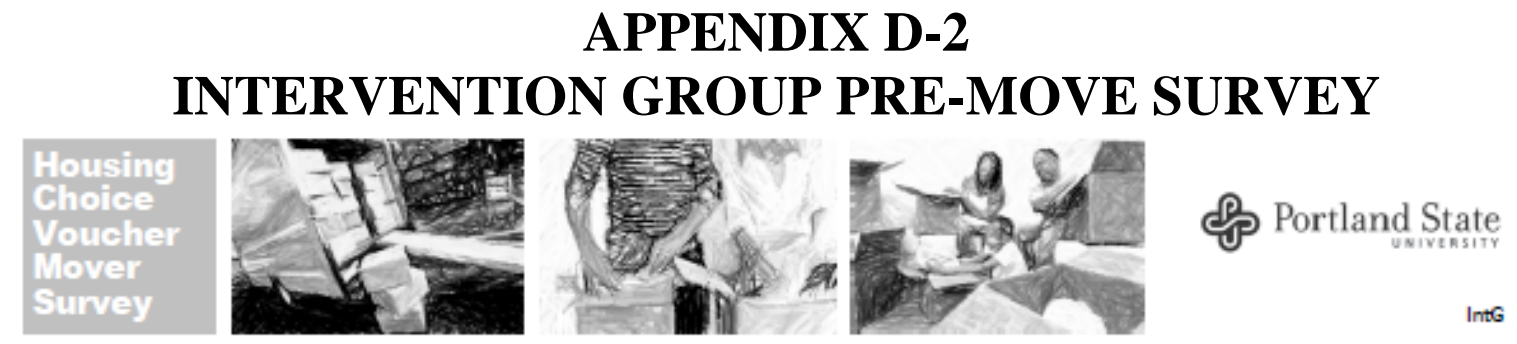

1. Thinking about your current home and neighborhood, to what extent do you agree with each statement?

\begin{tabular}{|c|c|c|c|c|}
\hline & $\begin{array}{l}\text { Strongly } \\
\text { agree }\end{array}$ & Agree & Disagree & $\begin{array}{l}\text { Strongly } \\
\text { Disagree }\end{array}$ \\
\hline $\begin{array}{l}\text { There are many places I go within easy walking distance } \\
\text { of my home. }\end{array}$ & $\square_{1}$ & $\square_{2}$ & $\square_{3}$ & $\square_{4}$ \\
\hline $\begin{array}{l}\text { It is easy to walk to a bus stop or light rail station from } \\
\text { my home. }\end{array}$ & $\square_{1}$ & $\square_{2}$ & $\square_{3}$ & $\square_{4}$ \\
\hline My neighborhood is a good place for walking. & $\square_{1}$ & $\square_{2}$ & $\square_{3}$ & $\square_{4}$ \\
\hline
\end{tabular}

2. How would you most likely get to each of the following places from your current home? Please check just one for each place.

\begin{tabular}{|c|c|c|c|c|c|}
\hline & Walk & $\begin{array}{c}\text { Public } \\
\text { Transportation }\end{array}$ & Car & Bicycle & $\begin{array}{c}\text { Don't go } \\
\text { there }\end{array}$ \\
\hline A grocery store & $\square_{1}$ & $\square_{2}$ & $\square_{3}$ & $\square_{4}$ & $\square_{\mathrm{N} / \mathrm{A}}$ \\
\hline Doctor or dentist & $\square_{1}$ & $\square_{2}$ & $\square_{3}$ & $\square_{4}$ & $\square_{\mathrm{N} / \mathrm{A}}$ \\
\hline Home of friend or relative I often visit & ㅁ. & $\square_{2}$ & $\square_{3}$ & $\square_{4}$ & $\square_{\text {Nia }}$ \\
\hline Store or shop (non-grocery) & $\square_{1}$ & $\square_{2}$ & $\square_{3}$ & $\square_{4}$ & $\square_{\text {N/A }}$ \\
\hline Children's school or childcare & $\vec{\square}_{1}$ & $\square_{2}$ & $\square_{3}$ & $\square_{4}$ & $\square_{\text {N/A }}$ \\
\hline Church or place of worship & $\square_{1}$ & $\square_{2}$ & $\square_{3}$ & $\square_{4}$ & $\square_{\mathrm{N} / \mathrm{A}}$ \\
\hline $\begin{array}{l}\text { Agency I need to visit (such as Social } \\
\text { Security or Housing Authority) }\end{array}$ & $\square_{1}$ & $\square_{2}$ & $\square_{3}$ & $\square_{4}$ & $\square_{\text {N/A }}$ \\
\hline My place of work & $\square_{1}$ & $\square_{2}$ & $\square_{3}$ & $\square_{4}$ & $\square_{\mathrm{N} / \AA}$ \\
\hline Post office & $\square_{1}$ & $\square_{2}$ & $\square_{3}$ & $\square_{4}$ & $\square_{\text {NiA }}$ \\
\hline Restaurant, café or bar & $\square_{1}$ & $\square_{2}$ & $\square_{3}$ & $\square_{4}$ & $\square_{\mathrm{N} / \mathrm{A}}$ \\
\hline A park & $\square_{1}$ & $\square_{2}$ & $\square_{3}$ & $\square_{4}$ & $\square_{\text {N/A }}$ \\
\hline Other: & $\square_{1}$ & $\square_{2}$ & $\square_{3}$ & $\square_{4}$ & $\square_{\mathrm{N} / \AA}$ \\
\hline
\end{tabular}

3. In the last week, how much of your daily travel was by each of the following? Do not include trips to work.

$\begin{array}{lccccc} & \text { None } & \text { A small } & & & \\ \text { amount } & \text { About half } & \text { Most } & \text { All } \\ \text { Walk } & \square_{0} & \square_{1} & \square_{2} & \square_{3} & \square_{4} \\ \text { Public transportation } & \square_{0} & \square_{1} & \square_{2} & \square_{3} & \square_{4} \\ \text { Car } & \square_{0} & \square_{1} & \square_{2} & \square_{3} & \square_{4} \\ \text { Bicycle } & \square_{0} & \square_{1} & \square_{2} & \square_{3} & \square_{4}\end{array}$

4. When you think about your new home, how much do you intend to walk, drive, use transit and bike for transportation purposes compared to your current home? Do not include trips to work.

\begin{tabular}{|c|c|c|c|c|c|c|}
\hline & Decrease a lot & $\begin{array}{c}\text { Decrease a } \\
\text { little }\end{array}$ & Stay the same & $\begin{array}{l}\text { Increase a } \\
\text { little }\end{array}$ & Increase a lot & Don't use it \\
\hline Walking & $\square_{0}$ & $\square_{1}$ & $\square_{2}$ & $\square_{3}$ & $\square_{4}$ & $\square_{\text {NIA }}$ \\
\hline Transit & $\square_{0}$ & $\square_{1}$ & $\square_{2}$ & $\square_{3}$ & $\square_{4}$ & $\square_{\mathrm{N} / \mathrm{A}}$ \\
\hline Driving & $\square_{0}$ & $\square_{1}$ & $\square_{2}$ & $\square_{3}$ & $\square_{4}$ & $\square_{\text {NIA }}$ \\
\hline \multirow[t]{2}{*}{ Bicycling } & $\square_{0}$ & $\square_{1}$ & $\square_{2}$ & $\square_{3}$ & $\square_{4}$ & $\square_{\text {NAA }}$ \\
\hline & & & & & Int $G$ & \\
\hline
\end{tabular}


5. How important are each of the following to you in choosing your new home?

\begin{tabular}{lcccc} 
Property and unit well-maintained & $\begin{array}{c}\text { Not at all } \\
\text { important }\end{array}$ & $\begin{array}{c}\text { Moderately } \\
\text { important }\end{array}$ & $\begin{array}{c}\text { Very } \\
\text { important }\end{array}$ & $\begin{array}{c}\text { Extremely } \\
\text { important }\end{array}$ \\
Helpful property manager & $\square_{1}$ & $\square_{2}$ & $\square_{3}$ & $\square_{4}$ \\
Good public transportation & $\square_{1}$ & $\square_{2}$ & $\square_{3}$ & $\square_{4}$ \\
Private yard & $\square_{1}$ & $\square_{2}$ & $\square_{3}$ & $\square_{4}$ \\
Shopping areas within walking distance & $\square_{1}$ & $\square_{2}$ & $\square_{3}$ & $\square_{4}$ \\
Good schools & $\square_{1}$ & $\square_{2}$ & $\square_{3}$ & $\square_{4}$ \\
Low transportation costs & $\square_{1}$ & $\square_{2}$ & $\square_{3}$ & $\square_{4}$ \\
Neighborhood feels safe & $\square_{1}$ & $\square_{2}$ & $\square_{3}$ & $\square_{4}$ \\
A place where I fit in & $\square_{1}$ & $\square_{2}$ & $\square_{3}$ & $\square_{4}$ \\
Sidewalks throughout the neighborhood & $\square_{1}$ & $\square_{2}$ & $\square_{3}$ & $\square_{4}$ \\
I know the area & $\square_{1}$ & $\square_{2}$ & $\square_{3}$ & $\square_{4}$ \\
Access to bike routes & $\square_{1}$ & $\square_{2}$ & $\square_{3}$ & $\square_{4}$ \\
Parks and open space nearby & $\square_{1}$ & $\square_{2}$ & $\square_{3}$ & $\square_{4}$ \\
Near family or friends & $\square_{1}$ & $\square_{2}$ & $\square_{3}$ & $\square_{4}$ \\
Places to eat in walking distance & $\square_{1}$ & $\square_{2}$ & $\square_{3}$ & $\square_{4}$ \\
Children's play areas & $\square_{1}$ & $\square_{2}$ & $\square_{3}$ & $\square_{4}$ \\
Easy access to a freeway & $\square_{1}$ & $\square_{2}$ & $\square_{3}$ & $\square_{4}$ \\
Biggest unit for the money & $\square_{1}$ & $\square_{2}$ & $\square_{3}$ & $\square_{4}$ \\
Walking distance to schools & $\square_{1}$ & $\square_{2}$ & $\square_{3}$ & $\square_{4}$ \\
Cheaper rent and utilities & $\square_{1}$ & $\square_{2}$ & $\square_{3}$ & $\square_{4}$ \\
Easy access to medical and social services & $\square_{1}$ & $\square_{2}$ & $\square_{3}$ & $\square_{4}$ \\
Other & $\square_{1}$ & $\square_{2}$ & $\square_{3}$ & $\square_{4}$ \\
\hline
\end{tabular}

6. How much do you agree or disagree with the following statements?

\begin{tabular}{|c|c|c|c|c|}
\hline & $\begin{array}{l}\text { Strongly } \\
\text { agree }\end{array}$ & Agree & Disagree & $\begin{array}{l}\text { Strongly } \\
\text { Disagree }\end{array}$ \\
\hline $\begin{array}{l}\text { If I wanted to, I could find a home within walking distance of } \\
\text { many places I need to go regularly. }\end{array}$ & $\square_{1}$ & $\square_{2}$ & $\square_{3}$ & $\square_{4}$ \\
\hline $\begin{array}{l}\text { If I wanted to, I could find a home where I would pay less for } \\
\text { transportation. }\end{array}$ & $\square_{1}$ & $\square_{2}$ & $\square_{3}$ & $\square_{4}$ \\
\hline $\begin{array}{l}\text { If I wanted to, I could find a home with good public } \\
\text { transportation that goes to the places I need to go. }\end{array}$ & $\square_{1}$ & $\square_{2}$ & $\square_{3}$ & $\square_{4}$ \\
\hline
\end{tabular}

7. Was your name recently pulled from the wait list for a Housing Choice (Section 8) Voucher?
$\square$ Yes
$\square$ No

8. How certain are you of where you want to live when you move?

I know which apartment or home I plan to move to.

$\begin{array}{crrr}\text { Strongly } & \text { Agree } & \text { Disagree } & \begin{array}{c}\text { Strongly } \\ \text { Disafree }\end{array} \\ \begin{array}{c}\text { Agree } \\ \square_{1}\end{array} & \square_{2} & \square_{3} & \square_{4}\end{array}$


9. Why are you moving?

$\square_{1}$ My landlord gave me notice or did not renew my lease, so I have to move.

$\square_{2}$ I am choosing to move; my landlord did not force me to move.

$\square_{3}$ My name was just pulled from the Housing Choice (Section 8) Voucher wait list.

10. How much do you agree or disagree with the following statements?

\begin{tabular}{|c|c|c|c|c|}
\hline & $\begin{array}{l}\text { Strongly } \\
\text { agree }\end{array}$ & Agree & Disagree & $\begin{array}{l}\text { Strongly } \\
\text { Disagree }\end{array}$ \\
\hline Walking can sometimes be easier for me than driving. & $\square_{1}$ & $\square_{2}$ & $\square_{3}$ & $\square_{4}$ \\
\hline Traveling by car is safer overall than walking. & $\square_{1}$ & $\square_{2}$ & $\square_{3}$ & $\square_{4}$ \\
\hline I prefer to walk rather than drive whenever possible. & $\square_{1}$ & $\square_{2}$ & $\square_{3}$ & $\square_{4}$ \\
\hline I like walking. & $\square_{1}$ & $\square_{2}$ & $\square_{3}$ & $\square_{4}$ \\
\hline $\begin{array}{l}\text { It would be nice to live in a place where I could get by without a } \\
\text { car for many of my needs. }\end{array}$ & $\square_{1}$ & $\square_{2}$ & $\square_{3}$ & $\square_{4}$ \\
\hline I like riding a bike. & $\square_{1}$ & $\square_{2}$ & $\square_{3}$ & $\square_{4}$ \\
\hline I like driving a car. & $\square_{1}$ & $\square_{2}$ & $\square_{3}$ & $\square_{4}$ \\
\hline Traveling by car is safer overall than riding a bike. & $\square_{1}$ & $\square_{2}$ & $\square_{3}$ & $\square_{4}$ \\
\hline Taking transit can sometimes be easier for me than driving. & $\square_{1}$ & $\square_{2}$ & $\square_{3}$ & $\square_{4}$ \\
\hline I prefer to take transit rather than drive whenever possible. & $\square_{1}$ & $\square_{2}$ & $\square_{3}$ & $\square_{4}$ \\
\hline I like taking public transportation. & $\square_{1}$ & $\square_{2}$ & $\square_{3}$ & $\square_{4}$ \\
\hline Traveling by car is safer overall than taking public transportation. & $\square_{1}$ & $\square_{2}$ & $\square_{3}$ & $\square_{4}$ \\
\hline I need a car to do many of the things I need to do. & $\square_{1}$ & $\square_{2}$ & $\square_{3}$ & $\square_{4}$ \\
\hline Biking can sometimes be easier for me than driving. & $\square_{1}$ & $\square_{2}$ & $\square_{3}$ & $\square_{4}$ \\
\hline
\end{tabular}

11. How much do you agree or disagree with the following statements?

I have friends or family who chose to live where they can get around mostly by walking.

I have friends or family who chose to live where they can get around mostly by public transportation.

I have friends or family who chose to live where they do not need a car to get around.

I have friends or family who chose to live where they can get around mostly by bicycling.

$\begin{array}{cccc}\begin{array}{c}\text { Strongly } \\ \text { agree }\end{array} & \text { Agree } & \text { Disagree } & \begin{array}{c}\text { Strongly } \\ \text { disagree }\end{array} \\ \square_{1} & \square_{2} & \square_{3} & \square_{4} \\ \square_{1} & \square_{2} & \square_{3} & \square_{4} \\ \square_{1} & \square_{2} & \square_{3} & \square_{4} \\ \square_{1} & \square_{2} & \square_{3} & \square_{4}\end{array}$

12. Are you:

$\square_{1}$ Male

$\square_{2}$ Female

13. In what year were you born?

14. Please write the number of people in your households that fall into each age category below. If none in that category, write zero $(0)$.

\begin{tabular}{|l|l|l|l|l|}
\hline Newborn through 5 & 6 through 15 & 16 through 18 & 19 through 61 & 62 and older \\
\hline & & & & \\
\hline
\end{tabular}


15. Do you consider yourself either Hispanic or Latino/a?

$\square_{0}$ No, not Hispanic or Latino

$\square$ Yes, Hispanic or Latino

16. Do you consider yourself

$\square$. White or Caucasian

$\square$. Black or African American

$\square$. American Indian or Alaska Native

$\square_{4}$ Asian

$\square$. Native Hawaiian or Other Pacific

$\square$. Multiracial

$\square_{7}$ Other (please specify):

17. Are you currently employed in a job outside your home?

$\square$, Yes, full-time

$\square_{2}$ Yes, part-time

$\square_{0}$ No

18. What is your annual household income? (Please check just one box.)
$\square_{1} \quad$ Less than $\$ 10,000$
$\square_{2} \quad \$ 10,000$ to $\$ 14,999$
$\square_{3} \quad \$ 15,000$ to $\$ 24,999$
$\square_{4} \quad \$ 25,000$ to $\$ 34,999$
$\square_{5} \quad \$ 35,000$ to $\$ 49,999$
$\square$ More than $\$ 50,000$

19. Which one of the following four statements best describes your ability to get by on your income?

$\square$ I l/we can't make ends meet

$\square_{2} \quad$ I/we have just enough, no more

$\square_{3} \quad$ I/we have enough with a little extra sometimes

$\square_{4} \quad \mathrm{l} /$ we always have money left over

20. Do you currently have a valid driver's license?

Yes

No

21. Do you have access to a car on most days?

22. Do you have access to a bicycle on most days?

23. Do you have a physical limitation that prevents you from walking for more than a few blocks?

24. Can you comfortably ride a bicycle?

25. Do you use a wheel chair or scooter regularly?

26. Have you received a toolkit from your housing authority to help you consider your daily transportation costs when choosing a new home?

27. What year did you move into your current home?

THANK YOU! Please return this survey to your Housing Authority staff person in envelope provided. S1 IntG 3/17/14 


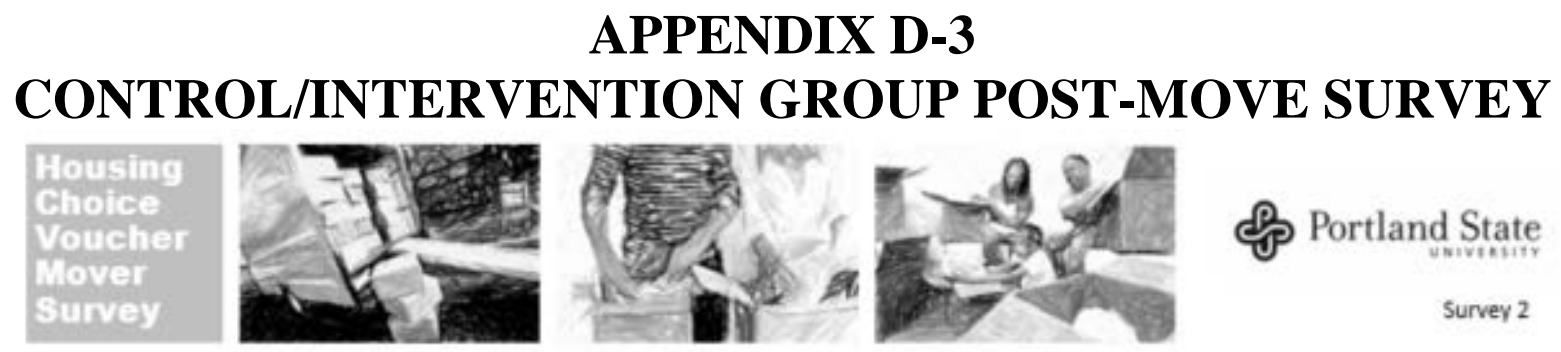

Congratulations on finding and moving to a new home. We are interested in learning about how you found your new home, what was important to you in choosing it, and how you get around-your transportation choices - now that you are settled. All your answers are confidential. Please complete this survey and return it to your housing authority in the envelope provided.

1. Thinking about your new home and neighborhood, to what extent do you agree with each statement?

There are many places I go within easy walking distance
of my home.
It is easy to walk to a bus stop or light rail station from
my home.
My neighborhood is a good place for walking.

2. How would you most likely get to each of the following places from your new home? Please check just one for each place.

\begin{tabular}{|c|c|c|c|c|c|}
\hline & Walk & $\begin{array}{c}\text { Public } \\
\text { Transportation }\end{array}$ & Car & Bicycle & $\begin{array}{l}\text { Don't go } \\
\text { there }\end{array}$ \\
\hline A grocery store & $\Pi_{1}$ & $\mathrm{~m}$ & $\Pi_{2}$ & $\Pi 4$ & Tiva \\
\hline Doctor or dentist & $\Pi_{1}$ & $\Gamma_{2}$ & $\Pi 3$ & $\Pi$ & ПMNA \\
\hline Home of friend or relative I often visit & $\pi$ & $\pi$ & $\Pi:$ & $\Pi e$ & గinia \\
\hline Store or shop (non-grocery) & $\Pi_{1}$ & $\Pi$ & $\Pi_{1}$ & $\Pi \rightarrow$ & Tivia \\
\hline Children's school or childcare & $\Pi$ & $\Pi$ & $\Pi a$ & $\Pi a$ & Tivia \\
\hline Church or place of worship & $\pi$ & $\Pi$ & $\Pi \pi$ & $\Pi \pi$ & TINA \\
\hline $\begin{array}{l}\text { Agency I need to visit (such as Social } \\
\text { Security or Housing Authority) }\end{array}$ & a & D2 & $\square$ & 口4 & 口Na \\
\hline My place of work & $\Pi_{1}$ & $\Gamma$ & $\Pi_{2}$ & $\Pi$ & חiva \\
\hline Post office & $\Pi_{1}$ & $\pi$ & $\Pi$ & $\Pi i$ & Tiva \\
\hline Restaurant, café or bar & 口 & $\square 2$ & $\square_{3}$ & 口. & पwa \\
\hline A park & 口: & $\square$ & $\square$ & $\square$ & पNA \\
\hline 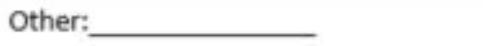 & $\square$ & $\square$ & $\square$ & $\square$ & 口NA \\
\hline
\end{tabular}

3. In the last week, how much of your daily travel was by each of the following? Do not include trips to work.

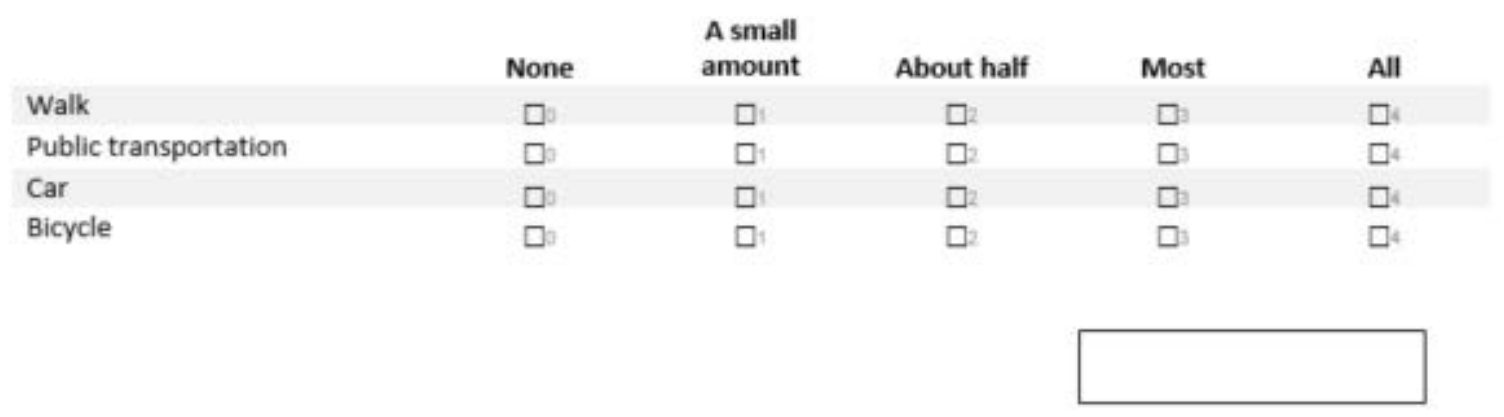


4. In your new home, how much do you walk, drive, yse transit and bike for transportation purposes compared to your former home? Do not include trips to work.

\begin{tabular}{|c|c|c|c|c|c|c|}
\hline & Decrease a lot & $\begin{array}{c}\text { Decrease a } \\
\text { little }\end{array}$ & Stay the same & $\begin{array}{l}\text { Increase a } \\
\text { little }\end{array}$ & Increase a lot & Don't use it \\
\hline Walking & D? & 口i & $\square$ & ㅁ: & 口4 & DNiA \\
\hline Transit & 0 & $\square_{1}$ & D2 & D & $D_{4}$ & Dia \\
\hline Driving & 0 & $a_{1}$ & D & D. & D. & DNiA \\
\hline Bicycling & $\square$ & Di & $\square$ & 0 & $\square_{4}$ & Dia \\
\hline
\end{tabular}

5. How important were each of the following to you in choosing your new home?

Property and unit well-maintained
Helpful property manager
Good public transportation
Private yard
Shopping areas within walking distance
Good schools
Low transportation costs
Neighborhood feels safe
A place where I fit in

6. How did you search for and find a new place to live? 
7. All things considered, which home do you prefer to live in?

Mx former home

ㅁ. Mynew home

口i I like them about the same

8. Why?

9. Here's a list of tools for finding a new place to live. How familiar are you with each of them?

\begin{tabular}{|c|c|c|c|}
\hline & Not familiar & $\begin{array}{c}\text { Somewhat } \\
\text { familiar }\end{array}$ & $\begin{array}{c}\text { Very } \\
\text { familiar }\end{array}$ \\
\hline List of places for rent from my housing authority & $\square$ & $\square=$ & $\square$ \\
\hline Online map, like Google Maps or Yahoo Maps & $\square$ & $\square$ & $\square$ \\
\hline Transportation Cost Worksheet from my housing authority & $\square$ & Q2 & $\square$ s \\
\hline Walk Score Apartment Finder--Walkscore.com/apartments & $\square$ & $\square$ & $\square$ \\
\hline Craigslist.org & $\square$ & $\square$ & $\square$ \\
\hline GoSection8.com & 미 & 口2 & $\square$ \\
\hline Check it Out checklist from my housing authority & $\square$ & 물 & 口) \\
\hline My housing authority's video on housing \& transportation costs & 口 & D. & $\square$ \\
\hline Transpo-rent.org & $\square$ & $\square$ & $\square \mathrm{s}$ \\
\hline Transportation Toolkit for Movers from my housing authority & $\square$ & $\square$ & $\square$ \\
\hline
\end{tabular}

10. How important were each of these in your search for a new home?

\begin{tabular}{|c|c|c|c|c|}
\hline & $\begin{array}{l}\text { Not at all } \\
\text { important }\end{array}$ & $\begin{array}{l}\text { Moderately } \\
\text { important }\end{array}$ & $\begin{array}{l}\text { Very } \\
\text { important }\end{array}$ & $\begin{array}{l}\text { Extremely } \\
\text { important }\end{array}$ \\
\hline List of places for rent from my housing authority & $\square 1$ & $\square$ & 口s & $\square 4$ \\
\hline Online map, like Google Maps or Yahoo Maps & $\square$ & $\square$ & $\square$ & $\square$ \\
\hline Transportation Cost Worksheet from my housing authority & $\square$ & $\square$ & $\square^{3}$ & $\square 4$ \\
\hline Walk Score Apartment--Walkscore.com/apartments & $\square$ & 口. & 口: & 口4 \\
\hline Craigslist.org & $\square$ & $\square_{2}$ & 口s & $\square$ \\
\hline GoSection8.com & $\square$ & 口: & 口s & $\square$ \\
\hline Check it Out checklist from my housing authority & $\square$ & $\square$ & $\square$ & $\square 4$ \\
\hline $\begin{array}{l}\text { My housing authority's video on housing \& transportation } \\
\text { costs }\end{array}$ & $\square$ & 口: & $\square$ & $\square$ \\
\hline Transpo-rent.org & $\square_{1}$ & $\square 2$ & $\square$ & $\square$ \\
\hline $\begin{array}{l}\text { Transportation Toolkit for Movers from my housing } \\
\text { authority }\end{array}$ & 口 & $\square_{2}$ & Q & 口4 \\
\hline Meeting with my housing authority representative & $\square_{1}$ & $\square^{2}$ & 口s & $\square$ \\
\hline Suggestions from friends or family & $\square$ & $\square$ & 口) & 口4 \\
\hline
\end{tabular}

11. Before you moved, did you receive information or a Transportation Toolkit from your housing authority to help you consider everyday transportation costs in choosing your new home? 
12. Now that you've moved, how have your costs for the following things changed?

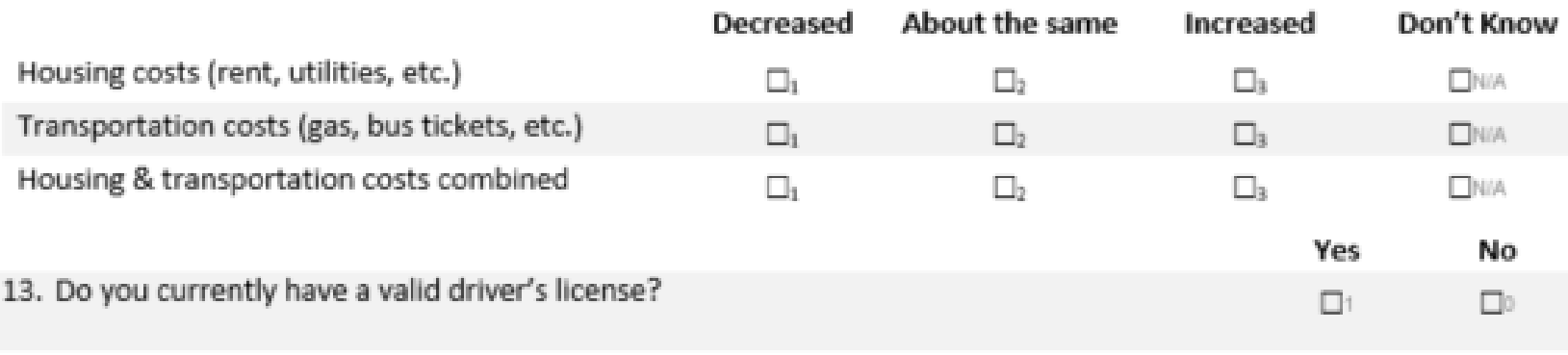

14. Do you have access to a car on most days?

15. Do you have access to a bicycle on most days?

16. Do you have a physical limitation that prevents you from walking for more than a few blocks?

17. Can you comfortably ride a bicycle?

18. Do you use a wheel chair or scooter regularly?

19. Please write the number of people in your households that fall into each age category below. If none in that category, write zero (0).

\begin{tabular}{|l|l|l|l|l|}
\hline Newborn through 5 & 6 through 15 & 16 through 18 & 19 through 61 & 62 and older \\
\hline & & & & \\
\hline
\end{tabular}

20. Are you currently employed in a job outside your home?
$\square$ ' Yes, full-time
ㅁ2 Yes, part-time
$\square \circ$ No

21. What is your annual household income? (Please check just one box.)
$\square 1$ Less than $\$ 10,000$
प2 $\$ 10,000$ to $\$ 14,999$
प 3315,000 to $\$ 24,999$
口4 $\$ 25,000$ to $\$ 34,999$
प. $\$ 35,000$ to $\$ 49,999$
प. More than $\$ 50,000$

22. Which one of the following four statements best describes your ability to get by on your income?

I/we can't make ends meet

प2 $1 /$ we have just enough, no more 


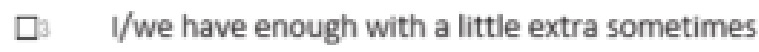

प4 1/we always have money left over

23. When did you move into your new home? Month Year

THANK YOU! Now send this survey to your Housing Authority in the stamped envelope provided to get your gift card.

Survey $2-3 / 21 / 14$ 


\title{
APPENDIX E \\ PROJECT INFORMATION SHEET FOR PARTICIPANTS
}
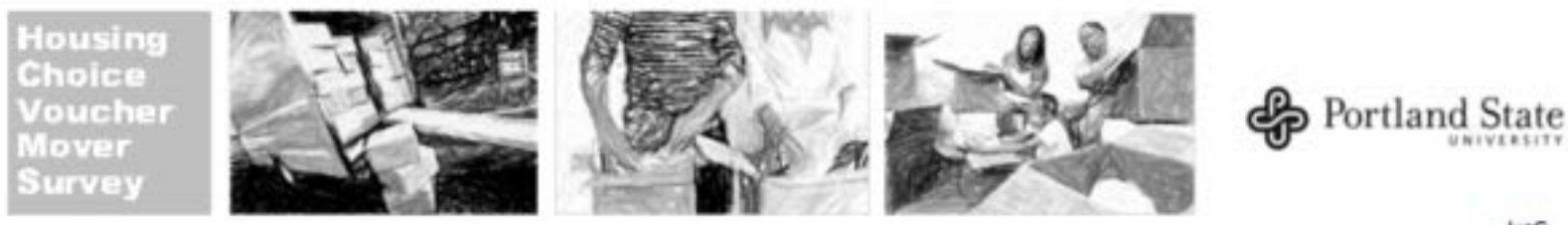

$\operatorname{Iat} G$

\author{
Be a Part of an Important Project \\ Transportation Information Program for Movers
}

Portland State University and four Housing Authorities - Home Forward, Vancouver Housing Authority, Housing Authority of Washington County and Housing Authority of Clackamas County- would like to ask for your help. We are working on a study called the Transportation Information Program for Movers. The study is about how transportation options figure into the housing choices people make. We are inviting you and other people who are planning to move to participate in a survey. If you are NOT planning to move, please do not complete this survey.

What is involved?

- Completing two surveys---one now and one after you move. Each will take about 10-15 minutes to complete.

- Your participation is voluntary. You do not have to take part if you do not want to. Your choice about participating will not affect your housing benefits (or any other benefits) or your relationship with the Housing Authority or Portland State University. You can change your mind about participating at any time.

What are the benefits to me?

- As a way of saying thank you, everyone who returns the second survey will receive a $\$ 10$ gift card. You have to complete the first survey to receive the second one.

- Your participation helps to improve housing authority programs that assist people who move.

What happens with the surveys?

- All of your responses are confidential. The PSU staff who review the surveys will not know who returned them. Your housing authority staff may know who participated, but they will not see your responses.

- Your housing authority will provide the addresses of survey participants to PSU. The addresses will be kept in a secure place at PSU, and no one besides the people working on the project will have access to the addresses.

- The study will only report on how groups of people responded, not how individuals responded. The report will not include home addresses or other information that would enable a reader to identify where participants live.

Who may I contact if I have questions?

- If you have any questions about this study, this form, or the survey, you can contact the person leading the project at Portland State University, Andree Tremoulet, at (503) 725-4075.

- You can also contact the Chair of the Human Subjects Committee of Portland State University at (503) 725-4288. The office is located at Portland State University, Market Center Building, $6^{\text {th }}$ floor, Portland, OR 97201.

Your Consent

- By completing and returning the survey, you are indicating that you have read this and consent to participate.

- Keep this information sheet for your records. Remember, your participation is voluntary.

To Get Started

- Complete the survey. Then put it in the envelope, seal the envelope, and return it with your move paperwork to your housing authority.

- If you would like help completing the survey, please contact your housing authority case manager/primary contact.

THANK YOU! THANK YOU! THANK YOU! 
Transportation Research and Education Center

Portland State University

1900 S.W. Fourth Ave., Suite 175

Portland, OR 97201 